\title{
DESMATAMENTO E RECUPERAÇÃO DE PASTAGENS \\ DEGRADADAS NA REGIÃO AMAZÔNICA: UMA \\ ABORDAGEM ATRAVÉS DAS ANÁLISES DE PROJETOS
}

\section{SILVIO MASSARU ICHIHARA}

Dissertação apresentada à Escola Superior de Agricultura "Luiz de Queiroz”, Universidade de São Paulo, para obtenção do título de Mestre em Ciências, Área de Concentração: Economia Aplicada

PIR A C I C A B A

Estado de São Paulo - Brasil

Outubro de 2003 


\title{
DESMATAMENTO E RECUPERAÇÃO DE PASTAGENS DEGRADADAS NA REGIÃO AMAZÔNICA: UMA ABORDAGEM ATRAVÉS DAS ANÁLISES DE PROJETOS
}

\section{SILVIO MASSARU ICHIHARA}

Médico Veterinário

Orientador: Prof. Dr. JOAQUIM BENTO DE SOUZA FERREIRA FILHO

\begin{abstract}
Dissertação apresentada à Escola Superior de Agricultura "Luiz de Queiroz", Universidade de São Paulo, para obtenção do título de Mestre em Ciências, Área de Concentração: Economia Aplicada
\end{abstract}

PIR A C IC A B A

Estado de São Paulo - Brasil

Outubro de 2003 
Dados Internacionais de Catalogação na Publicação (CIP) DIVISÃO DE BIBLIOTECA E DOCUMENTAÇÃO - ESALQ/ USP

\section{Ichihara, Silvio Massaru}

Desmatamento e recuperação de pastagens degradadas na região

amazônica: uma abordagem através das análises de projetos / Silvio Massaru Ichihara. - - Piracicaba, 2003.

$106 \mathrm{p}$.

Dissertação (mestrado) - - Escola Superior de Agricultura Luiz de Queiroz, 2003.

Bibliografia.

1. Amazônia 2. Desmatamento 3. Pastagens cultivada - Recuperação 4. Pecuária de corte 5. Viabilidade econômica I. Título

CDD 338.176 


\section{DEDICATÓRIA}

Dedico esse trabalho aos meus pais, Masaru Ichihara e Iaeko Kuwabara Ichihara, e a minha irmã, Cristina Ichihara, em gratidão a, simplesmente, tudo!

Dedico também a Mônica Keiko Magami Yamada, em gratidão ao companherismo e a todo o apoio que sempre me deu.

Se não houver frutos,

valeu a beleza das flores.

Se não houver flores,

valeu a sombra das folhas.

Se não houver folhas,

valeu a intenção da semente.

Henfil (1944-1988)

Embora meus pais não façam poemas acredito que esse seja o que expressa melhor seus ensinamentos. Muito Obrigado! 


\section{AGRADECIMENTOS}

Agradeço a todos os produtores rurais que, pacientemente, disponibilizaram tempo e informações, tornando possível a realização deste trabalho com dados fidedignos de várias regiões do País, e a quem espero que essa obra possa de alguma forma retribuir esse favor.

Agradeço ao Departamento de Economia, Administração e Sociologia da Escola Superior de Agricultura 'Luiz de Queiroz", em especial aos professores do curso de PósGraduação em Economia Aplicada, pelos ensinamentos e dedicação. Agradecimentos específicos aos professores:

- Prof. Joaquim Bento de Souza Ferreira Filho, pela orientação na elaboração deste estudo;

- Prof. Fernando Curi Peres, por participar de todas as etapas que envolveram a produção desta dissertação, do seminário até a defesa, e por me apresentar o universo das técnicas da pesquisa operacional, nas quais pretendo me aperfeiçoar e dirigir meus estudos futuros.

- Prof. Sergio De Zen, por participar ativamente da produção desta dissertação, pelas valiosas sugestões que fez ao longo de toda a produção desse trabalho e pela oportunidade conferida a mim para realizar estudos sobre a pecuária de corte nas principais regiões do Brasil.

- Prof. Alexandre L. Mendonça de Barros, pelas importantes colocações que determinaram as principais análises deste estudo e ainda pela excelência dos conselhos passados a mim, que não se prendem apenas à academia, mas também aos assuntos tratados fora dela. 
- Profa. Márcia Azanha Ferraz Dias de Moraes, pelas sugestões feitas na fase inicial.

Agradeço ao Centro de Estudos Avançados em Economia Aplicada e a todos os funcionários e pesquisadores a ele integrados e faço agradecimentos especiais:

- À assessora de comunicação, Ana Paula da Silva, por me ajudar de todas as formas e especialmente por ter acreditado em mim, mesmo nas horas em que eu não o fz Faço apenas uma observação neste parágrafo, pois atenho meus agradecimentos apenas ao que se relaciona a essa dissertação, mas deixo registrado aqui que devo muitos outros agradecimentos a essa magnífica pessoa.

- Aos pesquisadores Leandro A. Ponchio e Mauro Osaki pelo companherismo e por me auxiliarem na fase de coleta de dados, especialmente nas viagens aos pontos mais remotos do país, enfrentando estradas e caminhões que simplesmente desabam em cima dos carros.

Agradeço ao Centro de Estudos em Energia Nuclear, em especial ao Prof. Carlos Clemente Cerri, pela oportunidade de participar do projeto temático envolvendo a recuperação de pastagens na região amazônica.

Agradeço ao pesquisador científico Luís Alberto Ambrósio do IAC, pela participação na banca de defesa e pelas sugestões apresentadas na finalização deste trabalho.

Agradeço aos pesquisadores científicos, Flávia Maria de Mello Bliska da APTA e Vicente de Paula Campos Godinho (Embrapa-RO) que por diferentes formas fizeram grandes contribuições a este trabalho.

Agradeço às secretárias que muito me auxiliaram: Luciane C. Scafi (CEPEA), Mara Casarin (CENA) e, em especial, Maria A. Maielli Travalini (Pós-Graduação LES), a quem considero um exemplo de que a fusão entre o sorriso e a competência pode se dar em todos os dias de todos os anos.

Agradeço à Ligiana Clemente do Carmo e ao Álvaro Sobreiro Filho por zelarem pelo local que considero mais importante de toda a infra-estrutura do departamento. 
Agradeço à CAPES, a CNPQ e à FAPESP por financiarem as várias etapas dessa pesquisa.

Por fim, mas não em menor importância, faço agradecimentos aos colegas e amigos que conheci nos anos em que cursei a mestrado em economia, destacando:

- Lucílio A. Alves, por me manter sempre informado sobre pontos importantes da academia e, juntamente com Ronaldo Z. Correia, serem grandes companheiros;

- Gustavo Talhalenha, por me ajudar muito no começo do curso;

- Joaquim H. Cunha e Julcemar B. Zilli, Ricardo Lopes, Marcos Hasegawa, Alexandre Nunes de Almeida e outros tomadores de cerveja com os quais tive boas discussões e por dias tiveram que ficar ouvindo meus desabafos;

- Elisson Augusto Pires de Andrade, por ser um dos melhores exemplos de eficácia, em quase todos os aspectos, que conheci nesta universidade e por ser um grande amigo;

- Alexandre Cibele Nicolella, pelo grande auxílio nos estudos, pelo companherismo até em viagens para locais que poucos se dispõem a ir, pelo exemplo de que ser chato fazendo reclamações concisas pode trazer benefícios que vão muito além do que era esperado e, obviamente, pela grande amizade. 


\section{SUMÁRIO}

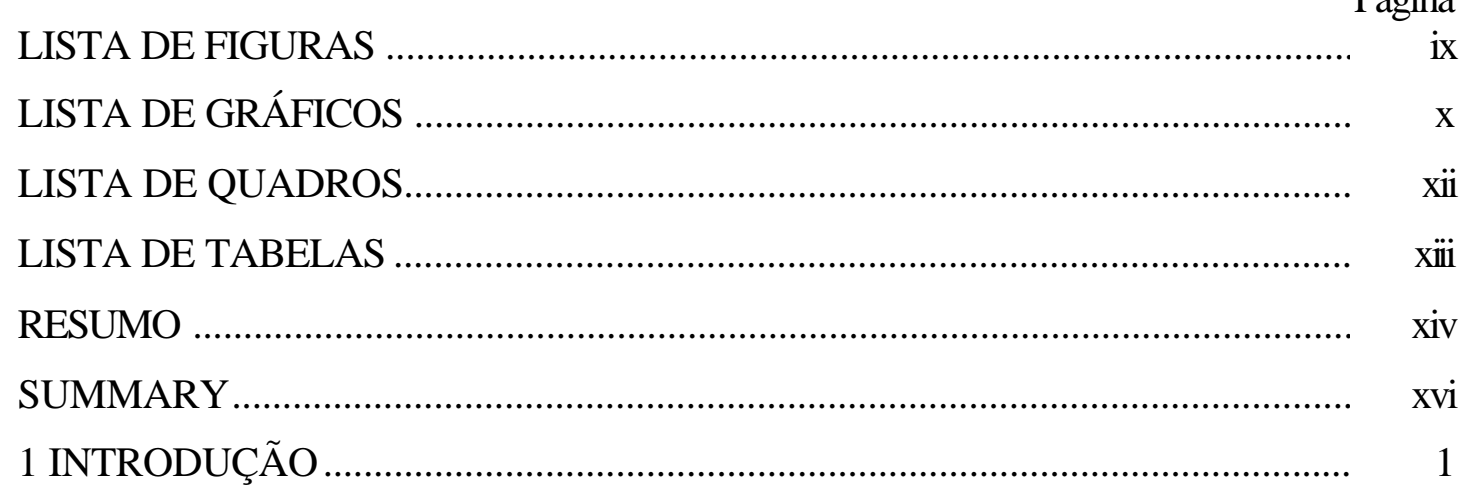

1.1 Descrição do problema ....................................................................................... 2

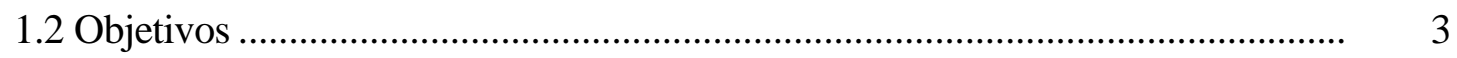

2 REVISÃO DE LITERATURA ...................................................................... 4

$2.1 \mathrm{O}$ desenvolvimento da pecuária na região amazônica ........................................... 4

$2.2 \mathrm{O}$ processo de adoção de tecnologias ................................................................... 8

2.3 A avaliação de projetos ................................................................................... 9

2.4 A incorporação do risco em análises econômicas .............................................. 10

3 MATERIAL E MÉTODOS _.......................................................................... 14

3.1 O levantamento de dados primários ................................................................... 15

3.1.1 Levantamento de dados primários através de painéis ..................................... 16

3.1.2 Levantamento de dados primários através de entrevistas ............................... 20

3.1.3 Levantamento de dados de outras importantes regiões - pecuária de corte ...... 21

3.2 A definição de uma propriedade típica ............................................................... 24

3.3 Descrição dos projetos envolvidos ................................................................... 27

3.3.1 "Projeto 1" (propriedade sem alterações)........................................................ 31

3.3.2 "Projetos 2, 3, 4 e 5" (sistemas de recuperação de pastagens degradadas)...... 32 
3.3.3 "Projeto 6" venda da propriedade e instalação de uma nova através do desmatamento

3.3.4 Considerações sobre a mão-de-obra

3.3.5 Considerações sobre os cálculos dos custos fixos ..

3.3.6 Considerações sobre os cálculos de horas trabalhadas por máquinas. 48

3.4 Análises 49

3.4.1 Avaliação econômica determinista 49

3.4.2 Avaliação econômica sob condições de risco

3.5 Instrumental utilizado para formação dos fluxos de caixa e da promoção das análises.

3.6 A rotina de programação para cálculo da evolução do rebanho

3.7 A questão do preço da terra nas análises de viabilidade econômica dos projetos.

4 RESULTADOS E DISCUSSÃO . 73

4.1 Resultados da estimativa de evolução do rebanho... 73

4.2 Resultados das análises 77

4.2.1 Resultados - análise A 78

4.2.2 Resultados - análise B1 79

4.2.3 Resultados - análise B2 80

4.2.4 Resultados - análise B3 81

4.2.5 Resultados - análise B4 82

4.3 Discussão e realização de novas análises 87

4.3.1 O uso do IGP-DI para deflacionar as séries de preços

4.3.2 A taxa de lotação e a viabilidade econômica do projeto 1 (sem alterações) ..... 88

4.3.3 A diferença dos riscos associados aos projetos.

4.3.4 A viabilidade econômica do desmatamento em relação às práticas de recuperação de pastagem.

5 CONCLUSÕES 


\section{LISTA DE FIGURAS}

Página

$1 \quad$ Sistemática operacional da pesquisa ................................................................. 15

2 Desflorestamento e áreas importantes para a pecuária: sul do Estado do Pará... 19

3 Desflorestamento e áreas importantes para a pecuária: norte do Estado do

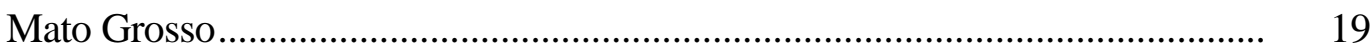

4 Avanço da pecuária nas últimas décadas. ......................................................... 22

5 Disposição dos municípios onde foram realizados os painéis. ............................ 23

6 O processo de formação das pastagens ................................................................ 42

$7 \quad$ Simbologia da programação ........................................................................... 60

8 Fluxograma principal .................................................................................. 61

9 Subrotina "Evolução M" ................................................................................. 62

10 Subrotina "Adição GP"................................................................................... 63

11 Subrotina "Evolução F".......................................................................................... 65

12 Subrotina "Adição GPF" .................................................................................... 66

13 Sequiência de análises relativas à precificação da terra no encerramento dos projetos 


\section{LISTA DE GRÁFICOS}

Página

1 Area dos estabelecimentos por grupo de atividade econômica (pecuária)....... 26

2 Percentual do capital investido na propriedade representativa ........................ 26

3 Distribuição sazonal das chuvas: variações e médias mensais. ....................... 29

4 Disposição dos preços reais da terra em RO, no último 10 anos. .................... 72

5 Capacidade de suporte da pastagem e total de UA por mês - projeto 1 .......... 74

6 Capacidade de suporte da pastagem e total de UA por mês - projeto 2 .......... 75

7 Capacidade de suporte da pastagem e total de UA por mês - projeto 3 .......... 75

8 Capacidade de suporte da pastagem e total de UA por mês - projeto 4 .......... 76

9 Capacidade de suporte da pastagem e total de UA por mês - projeto 5 .......... 76

10 Capacidade de suporte da pastagem e total de UA por mês - projeto 6 .......... 77

11 TIR resultante - análise A (sem o valor da terra) ........................................... 78

12 RBC resultante - análise A (sem o valor da terra)......................................... 78

13 TIR resultante - análise B1 (com o valor da terra, mas sem agregar

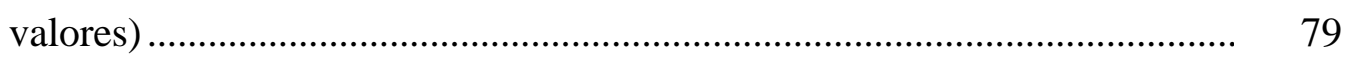

14 RBC resultante - análise B1 (com o valor da terra, mas sem agregar

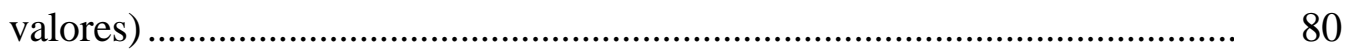

15 TIR resultante - análise B2 (com o valor da terra, agregando valor apenas ao projeto 6 desmatamento) ................................................................... 80

16 RBC resultante - análise B2 (com o valor da terra, agregando valor apenas ao projeto 6 desmatamento) ................................................................... 81

17 TIR resultante - análise B3 (agregando proporcionalmente o valor a todos os projetos).

$18 \mathrm{RBC}$ resultante - análise B3 (agregando proporcionalmente o valor a todos 
os projetos) (............................................................................... 82

19 TIR resultante - análise B4 (agregando o valor a todos os projetos) .............. 82

20 RBC resultante - análise B4 (agregando o valor a todos os projetos)............. 83

21 Projeto 4 - distribuição dos valores da RBC ................................................... 84

22 Projeto 5 - distribuição dos valores da RBC …................................................ 84

23 Projeto 6 - distribuição dos valores da RBC …………………………........... 85

24 TIR - Análise A - Utilizando 0,73 UA/ha no projeto 1 ................................. 90

25 RBC - Análise A - Utilizando 0,73 UA/ha no projeto 1 ............................... 90

26 Série de preços: Soja e Arroz ...................................................................... 94

27 Área autorizada e área desmatada, 1997-1999 .............................................. 96

28 Evolução do desmatamento - hectares por ano .............................................. 96 


\section{LISTA DE QUADROS}

Página

1 Fontes de informação - RO, MT, PA............................................................ 21

2 Ganhos de peso conforme os meses e as categorias de animais ....................... 30

3 Descrição dos sistemas de recuperação de pastagens a serem estudados ........... 33

4 Especificação da aplicação de defensivos, sementes e fertilizantes................... 34

5 Capacidade de suporte da propriedade - Projeto 2. Herbicida e adubação........ 36

6 Capacidade de suporte da propriedade - Projeto 3. Gradagem e adubação....... 38

$7 \quad$ Capacidade de suporte da propriedade - Projeto 4. Cultivo do arroz ................ 39

8 Capacidade de suporte da propriedade - Projeto 5. Cultivo da soja .................. 40

9 Capacidade de suporte da propriedade - Projeto 6. Desmatamento ................... 44

10 Ganhos de escala - Números de trabalhadores por unidades animais............... 46

11 Séries utilizadas nas simulações..................................................................... 58

12 Resultados da análise de sensibilidade para os projetos 1 e 2 - análise B4...... 92

13 Resultados da análise de sensibilidade para os projetos 3 e 4 - análise B4...... 92

14 Resultados da análise de sensibilidade para os projetos 5 e 6 - análise B4 ...... 93 


\section{LISTA DE TABELAS}

Página

1 Valores percentuais da produção de arroz, soja e do rebanho bovino por

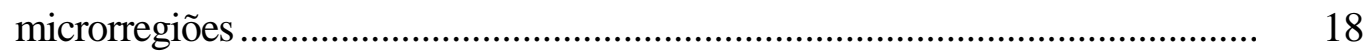

2 Características gerais da propriedade representativa ....................................... 25

3 Principais informações zootécnicas .............................................................. 25

$4 \quad$ Percentuais de área da pastagem recuperada por ano ..................................... 27

$5 \quad$ Taxas de lotação por ha - Projeto 1 ................................................................. 31

$6 \quad$ Capacidade de suporte da propriedade - Projeto 1 ......................................... 32

$7 \quad$ Taxa de lotação por ha - Projeto 2 Herbicida e adubação ................................. 35

8 Taxa de lotação por ha - Projeto 3 Gradagem e Adubação ............................... 37

9 Taxa de lotação por ha - Projeto 4 Cultivo do Arroz........................................ 38

10 Taxa de lotação por ha - Projeto 5 Cultivo da Soja ......................................... 39

11 Taxa de lotação por ha - Projeto 6 Estimativa não linear da perda da taxa de lotação por ano ....................................................................................... 43

12 Valores para conversão em unidades de trabalho ............................................. 47

13 Resultados - VPL, para a última observação a análise B4 .............................. 86

14 Resultados - PBE, para a última observação a análise B4 ............................. 86 


\title{
DESMATAMENTO E RECUPERAÇÃO DE PASTAGENS DEGRADADAS NA REGIÃO AMAZÔNICA: UMA ABORDAGEM ATRAVÉS DAS ANÁLISES DE PROJETOS
}

\author{
Autor: SILVIO MASSARU ICHIHARA
}

Orientador: Prof. Dr. JOAQUIM BENTO DE SOUZA FERREIRA FILHO

\section{RESUMO}

Este estudo teve como objetivo principal avaliar economicamente seis projetos associados a sistemas distintos de produção da pastagem, sendo que um deles não adota tecnologias suplementares àquelas observadas no manejo convencional, atuando como testemunha. Os quatro projetos seguintes foram criados a partir de diferentes técnicas de recuperação de pastagens: adubação associada ao uso de herbicidas; gradagem e adubação; recuperação através do cultivo de arroz; e recuperação através do cultivo da soja. O último relaciona-se com a opção do desmatamento para a abertura de novas áreas de pastoreio, ao invés da intensificação do uso de áreas já exploradas. Para classificar os projetos foram utilizados métodos convencionais de análises de projetos (TIR, VPL, RBC, PBE), tendo os dados empregados nas análises sidos coletados através de painéis e entrevistas com técnicos, na região amazônica e em outros importantes estados para a produção pecuária do Centro-Oeste. Embora o estudo faça inferências para a região amazônica, destaca-se que as análises voltaram-se ao estado de Rondônia, tendo em vista a disponibilidade de informações específicas quanto æ̀ formas de recuperação da pastagem, referentes às áreas experimentais desenvolvidas pelo projeto temático: 
FAPESP N N $^{\circ}$ 2000/08/239-2, empreendido pelo CENA/USP. Em linhas gerais, a ordem de preferência econômica entre os projetos é alterada por modificações em algumas variáveis. Destacam-se como variáveis principais que têm a capacidade de definir a preferência dos projetos: a taxa de lotação inicial, a hipótese de valorização da terra (vinculada ao potencial de desenvolvimento regional e à alteração de preço de acordo com os investimentos feitos na execução dos projetos). Também importante, mas que não foram analisados, itens como a forma gerencial de condução das vendas de animais nos períodos de entressafra e o horizonte temporal adotado podem promover alteração na ordem de escolha. Como resultados principais, pôde-se constatar que o projeto testemunha foi preferível em situações em que o percentual da valorização da terra é baixo. Entretanto, quando os valores associados à valorização da terra são somados, a melhor escolha, em termos econômicos, volta-se para a opção do desmatamento, dentro das considerações assumidas neste estudo. Essas considerações derivam da generalização de dados individuais para coeficientes regionais, o que torna alguns aspectos deficientes. A diversidade de tipos edafo-climáticos e os diversos sistemas de produção do complexo amazônico dificultam a formalização de conclusões que possam ter grande abrangência. Por isso foi criada uma planilha utilizando-se os recursos do Excel (disponibilizada no CD-ROM anexo), que possibilita a inclusão de informações distintas daquelas usadas neste estudo. A planilha visa, portanto, a contribuir com o processo individual de tomada de decisões dos agentes ligados ao setor da pecuária extensiva. 


\title{
DEFORESTATION AND RECOVERY OF PASTURES DEGRADED IN THE AMAZON: A BOARDING THROUGH THE ANALYSES OF PROJECTS
}

\author{
Author: SILVIO MASSARU ICHIHARA \\ Adviser: Prof. Dr. JOAQUIM BENTO DE SOUZA FERREIRA FILHO
}

\section{SUMMARY}

The aim of this study is to economically evaluate six projects associated to distinguished forms of pasture handling, one of them does not adopt supplementary technologies of handling, acting as a witness. The four following projects were developed from unique techniques of pasture recovering: manuring associated to the use of herbicides; tillage and manuring; recovering through rice growing; and recovering through soybean growing. The latter is related to the option for deforesting in order to provide new areas for pasture, instead of overloading the areas already explored. To classify the projects it was used conventional methods of project analysis (TIR, VPL, RBC, PBE), and the data used in the analysis were collected through panels and interviews with technicians, in the Amazon region and in other important states of cattle raising in the middle-west. Even though the study makes remarks on the Amazon region, it points out that the analysis were focused on the Rondonia state, considering the availability of specific information about the forms of pasture recovering, regarding the experimental areas developed by the theme project: FAPESP no. 2000/08/239-2 carried out by CENA / USP. In general terms, the order of preference among the projects is altered by 
modifications in some variables. As main variables, which are in a position to define the preference of the projects, we have: the initial allotment rate, the hypothesis of land valorization (linked to the regional development potential and to the prices changes according to the investments made in order to carry out the projects). Also important, however not analyzed, items such as the management way of conducting animal sales in times between harvests and the temporary horizon adopted can alter the order of choice. As main results, it was possible to conclude that the witness project was preferred in situations in which land valorization is low. However, when the values related to land valorization are added up, the best choice, in economic terms, comes back to the option for deforestation, within the consideration assumed in this study. These considerations derive from the generalization of individual data for regional coefficients, which make a few aspects deficient. The diversity of types of soil and weather and the various production systems of the Amazon complex make it difficult to formalize conclusions of large range. As a result, it was developed a spreadsheet making use of the resources of Excel (made available on the attached compact disc), which makes it possible to nclude distinct information of that used in this study. The spreadsheet aims to; therefore, contribute to the individual process of decision making of the agents involved in the extensive cattle raising sector. 


\section{INTRODUÇÃO}

A junção das palavras Amazônia, meio ambiente, desenvolvimento econômico e desmatamento originam o polêmico tema anexado à pauta da opinião pública mundial. $\mathrm{O}$ Tema é composto por uma complexa malha de ações antrópicas, que responsabiliza a atividade da pecuária extensiva como um dos principais agentes supressores da floresta.

Acerca dessa perspectiva, existe a necessidade de buscar alternativas que promovam o desenvolvimento regional, mas sem perder de vista as considerações sobre a sustentabilidade, de forma que o solo seja considerado um recurso natural renovável.

Dentre as tecnologias destinadas a contornar este problema, as técnicas empregadas na recuperação de pastagens mostram-se eficazes, pois aumentam a capacidade de produção do solo das regiões em vias de degradação. Entretanto, faz-se necessária a avaliação das vantagens econômicas relacionadas com a inclusão dessas tecnologias nos sistemas de produção locais, haja vista que esse ponto é, muitas vezes, decisivo no processo de tomada de decisão.

Este estudo visa à avaliação de quatro diferentes técnicas empregadas na recuperação de pastagens na região amazônica. A análise possui enfoque estritamente econômico e tem o intuito de fornecer resultados que se prestem ao auxílio, tanto das empresas privadas locais que desenvolvem a atividade pecuária, como dos órgãos públicos ou instituições não-governamentais voltadas à questão ambiental na região amazônica ${ }^{1}$.

\footnotetext{
${ }^{1}$ As informações geradas através das análises econômicas também irão auxiliar as análises finais do Projeto temático (FAPESP N 2000/08/239-2): "Avaliação de sistemas de recuperação de pastagens degradadas na amazônia", desenvolvido pelo Centro de Estudos de Energia Nuclear - CENA / Universidade de São Paulo- USP.
} 
Os subitens posteriores procuram apresentar e justificar o escopo deste trabalho. Nos itens subseqüentes, apresenta-se a revisão de Iteratura referente aos tópicos centrais envolvidos no estudo, os material e métodos que foram utilizados no desenvolvimento das análises econômicas e os resultados obtidos.

\subsection{Descrição do problema}

Ao longo dos anos, diferentes conotações foram dadas à região amazônica. Antes, foi considerada uma inóspita barreira verde, quase intransponível, que precisava ser vencida para que o progresso alcançasse os pontos mais remotos do país; hoje, é uma magnífica reserva de elementos orgânicos e minerais que ainda sobrevive à expansão humana e, pacientemente, espera pelo amadurecimento da consciência ambiental.

Poucos anos separam essas duas formas de observar a Amazônia Legal. Na década de 1970, o Governo Federal subsidiou a construção de rodovias e a implantação de diversos mecanismos de incentivo à colonização que, juntamente com investimentos de capitais estrangeiros na extração de recursos minerais, promoveram a consolidação de uma infra-estrutura capaz de alavancar o desenvolvimento das áreas limítrofes da floresta, favorecendo a transformação de grandes áreas de mata em áreas cultiváveis. Já na década de 1990, as questões ambientais incorporaram-se definitivamente à pauta das reuniões internacionais e o desenvolvimento vinculado ao desmatamento assumiu uma concepção negativa. Com isso, criou-se um impasse: como continuar o desenvolvimento sem desrespeitar a floresta?

Antes, a tecnologia utilizada na região voltava-se, exclusivamente, para a eficiência do processo de derrubada das florestas e à exploração de seus recursos. Homens e máquinas avançavam sem nenhuma forma de planejamento e o sucesso thes era proporcionado pela abundância do insumo terra. A imensidão da floresta permitiu o avanço do processo que envolvia a extração máxima dos recursos, o abandono e a substituição da área explorada por uma nova. Mas, em resposta à questão citada anteriormente, as tecnologias vinculadas ao manejo do solo e à sustentabilidade dos sistemas de produção, estagnadas até então, apresentam-se como possíveis soluções para resolver essa questão. 
Dentre as principais atividades econômicas que interagem com a floresta Amazônica, a pecuária talvez seja a mais polêmica. Por um lado, apresenta um caráter avassalador devido à exigência de grandes áreas de pastagens formadas por meio da derrubada e queima da mata e, por outro, tem um perfil pioneiro por estabelecer o direito da posse da terra e facilitar o posterior uso do solo para culturas agrícolas mecanizadas.

Nesse contexto, a recuperação de pastagens degradadas é uma possível solução tecnológica que pode ser utilizada para reduzir o impacto que a atividade pecuária representa à biodiversidade da floresta Amazônica e, ao mesmo tempo, melhorar a produtividade animal, favorecendo também a economia regional. Portanto, faz-se necessária a realização de trabalhos de pesquisa que definam as tecnologias mais viáveis econômica e ambientalmente, resultantes da combinação de métodos para a recuperação de áreas que seriam eventualmente abandonadas.

\subsection{Objetivos}

O objetivo geral deste trabalho é analisar, comparativamente, a viabilidade econômica de seis sistemas de produção relacionados com a pecuária de corte, na região amazônica. Quatro sistemas adotam práticas agronômicas destinadas ao processo de reabilitação de pastagens, enquanto que os outros dois sistemas refletem as opções de não adotar qualquer tipo de técnica e de promover o desmatamento. 


\section{REVISÃO DE LITERATURA}

\subsection{O desenvolvimento da pecuária na região amazônica}

Antes da década de 50, a pecuária, praticamente sem expressão, desenvolvia-se nos campos de pastagens nativas e de várzeas inundáveis distribuídos em algumas regiões do Pará, Tocantins, Mato Grosso, Amapá e Roraima. Com a necessidade de povoar os grandes vazios demográficos da região Norte, o Governo Federal, nas décadas de 60 e 70, construiu as rodovias Belém-Brasília, a atual BR-364, e a Transamazônica, além de estabelecer o INCRA (Instituto Nacional de Colonização e Reforma Agrária) e fomentar outros organismos de colonização. Tais fatores beneficiaram o desenvolvimento local e a expansão da pecuária regional

No início da década de 70, alguns estudos e relatos jornalísticos sobre a construção da Transamazônica apontavam a fragilidade da floresta frente à ação antrópica e questionavam a validade do enorme empenho do governo para povoar as grandes áreas inóspitas da região (Pereira, 1971; Gontijo, 1970). Desde aquela época, a atividade pecuária na região é apontada como predatória e causa da intensificação do processo de desertificação. Segundo esses relatos, a pecuária era utilizada como uma forma de evitar a ocupação de áreas "improdutivas" por "posseiros".

A atividade só se tornava lucrativa devido ao baixo preço de aquisição da terra, subsidiada pela SUDAM (Superintendência do Desenvolvimento da Amazônia). Além disso, a venda da madeira extraída na própria área gerava recursos suficientes para pagar o custo da terra, o desmatamento, a queimada, a plantação da pastagem e, ainda, a aquisição de todo o gado necessário para iniciar rebanho. O proprietário, então, usufruía a fertilidade proveniente das cinzas da queimada por alguns poucos anos e depois abandonava a terra (Thamer, 1970). 
Os ganhos originados do excelente crescimento das forrageiras, proporcionados pelos nutrientes das cinzas, foram observados por Falesi (1976). Os estudos realizados na década de 80 descrevem a redução da fertilidade do solo, apontando a importância da recuperação dos pastos degradados. A viabilidade da atividade pecuária sem os benefícios concedidos nas décadas anteriores passa, então, a ser questionada.

Falesi \& Veiga (1986) concluem que a técnica de recuperação de pastagens só se torna viável através de financiamentos acessíveis devido ao alto custo da utilização de máquinas pesadas e de fosfato aplicado em grande quantidade.

Hecht et d. (1998) demonstram através de métodos de simulação que a pecuária na Amazônia Oriental só se torna lucrativa em cenários que envolvam sobrepastejo, ou incentivos fiscais, ou empréstimos a juros baixos, ou especulação da terra, ou apresentem relação alta de preço do produto com preço dos insumos, ou ainda a combinação de todas essas situações. No entanto, tais cenários são contestáveis, devido aos seguintes fatores:

i) O sobrepastejo já não é tão usual, pois depende da abertura de novas áreas e das queimadas para que as cinzas possam ser agregadas ao solo, proporcionando o alto desempenho da pastagem por alguns anos (Falesi \& Veiga, 1986). Muitas das pastagens em uso atualmente foram formadas nas décadas de 70 e 80 , por isso a fertilidade proveniente das cinzas já não é tão relevante. Além disso, o processo de abertura de novas áreas esbarra na pressão imposta pela sociedade, fato decorrente do forte apelo internacional em defesa das áreas ambientais remanescentes e da preocupação com as questões referentes às alterações climáticas. A ênfase dada a esses fatores culminou com a publicação da Medida Provisória $\mathrm{N}^{\circ}$ 2.166-67, de 24-08-2001, de forma a alterar a redação do artigo 16 da Lei Federal $N^{\circ} 4771$ de 15/09/1965. O novo texto do artigo $\mathrm{n}^{\circ}$ 16 define como área de reserva legal oitenta por cento, no mínimo, da propriedade rural situada em qualquer região da Amazônia Legal (Brasil, 2001).

ii) A obtenção de capitais a juros baixos provenientes de planos e incentivos governamentais é cada vez mais difícil, seguindo o mesmo caminho da política agrícola nacional, nas décadas anteriores o crédito era facilitado para as iniciativas que visavam a colonização da área. 
iii) Segundo Homma (1993), expansão da fronteira agropecuária na região amazônica não pode ser explicada pelos lucros obtidos com especulação da terra, pois o risco decorrente da invasão de posseiros, a distância dos principais centros urbanos e a inexistência de preços excepcionais de produtos agrícolas produzidos na região interferem no preço da terra.

iv) Considerar alta a relação entre o preço do produto e preço dos insumos pode ser uma atitude errônea. É fato que os preços dos insumos destinados ao manejo mineral, profilático e reprodutivo, não produzidos nesta região, tendem a ser maiores devido ao pagamento do frete e, pelo mesmo motivo, o inverso ocorre com o preço dos produtos .

A despeito desses fatores adversos, a produção de bovinos continua a aumentar nos últimos anos na região amazônica.

Scheneider et al. (2000) relatam baixas taxas de retorno encontradas para a atividade pecuária e citam diversos outros autores que apresentam resultados parecidos, não conseguindo ajustar uma justificativa econômico-financeira para o aumento do rebanho bovino.

Mattos \& Uhl (1996) encontraram resultados parecidos com aqueles mencionados no parágrafo anterior, com taxas internas de retorno baixas e até negativas para a pecuária de corte. Porém, as conclusões também evidenciam taxas internas de retorno acima de $20 \%$ para a mesma atividade quando utilizava a técnica de eforma de pastagens. Tais técnicas são bastante recomendadas por diversos estudiosos. Segundo Costa (2000), a baixa fertilidade do solo em diversos locais da região amazônica limita a longevidade do cultivo das pastagens, que só se torna viável mediante a aplicação das técnicas de manejo e recuperação do pasto e, também, com o controle das plantas invasoras.

A necessidade do uso de tecnologia na pecuária no Brasil centro-norte não foi percebida somente nos últimos anos. Avaliando-se o trabalho realizado no Brasil central e descrito por Mueller (1977), que utiliza simulações com modelos de programação linear, nota-se que dentre as alternativas consideradas para explicar a baixa produtividade da pecuária (falta de crédito, política de preços e falta de alternativas viáveis), a falta de assistência técnica é um fator bastante problemático. 
$\mathrm{O}$ autor ressalta a importância das pesquisas destinadas à melhoria das variedades de pastagens mais adaptadas - fato que foi conseguido nas duas últimas décadas com o advento da Brachiaria brizanta, mas que ainda necessita de aperfeiçoamento, pois esta variedade de capim foi desenvolvida para o cerrado. O trabalho demonstra também a necessidade de implantar sistemas de manejo das pastagens relativamente simples, que não exijam mudanças drásticas na infra-estrutura das fazendas. A pesquisa mostra ainda que a mera adoção do método de pastoreio rotativo era capaz de aumentar significativamente a receita líquida da atividade.

É provável que a utilização de tecnologia para o setor pecuário tenha sido prorrogada em mais de uma década devido a vários fatores, mas talvez a abundância do recurso terra tenha sido o principal deles. Segundo Homma (1999), "A abundância da terra levou a um processo de regressão tecnológica dos migrantes, com relação aos locais de origem". O excesso deste insumo pode ter provocado a diminuição da demanda por tecnologia, visto que o desempenho da pecuária extensiva depende de grandes áreas de pasto disponíveis.

No entanto, a obtenção de terras e a realização do processo de transformação da floresta em pasto são ações relativamente mais difíceis de serem concretizadas hoje do que nas décadas anteriores, devido aos motivos mencionados anteriormente. Aliada a esse fator, a necessidade de assegurar os investimentos realizados na propriedade em termos de infra-estrutura faz com que os pecuaristas procurem alternativas para melhorar as áreas que já possuem em detrimento da abertura de outras não exploradas.

Por esses motivos, o uso de novas tecnologias pode contribuir para a expansão da pecuária bovina na região, mas as etapas de escolha e adoção de tecnologia se tornam mais complexas à medida que o respeito às variáveis ambientais aumenta. Isso faz com que sejam incluídos, nas análises das políticas desenvolvimentistas, fatores exógenos àqueles que se baseiam apenas nos anseios econômicos e financeiros. 


\subsection{O processo de adoção de tecnologias}

Diversos trabalhos que analisaram o processo de adoção de tecnologias na agricultura estão presentes na literatura econômica. Santos (1984) faz uma revisão geral dessas pesquisas, apresentando desde os estudos clássicos, empregados na agricultura americana, até os realizados no início da década de 1980, que exploram os variados setores agropecuários das diferentes regiões do Brasil. Os resultados dessas avaliações permitem compreender a importância da adoção da tecnologia e de sua difusão.

Entretanto, as diversas obras que analisam o processo de incorporação de tecnologias apresentam diferentes interpretações. Segundo Fonseca (1991), esse conjunto de obras tem como base duas abordagens principais, uma de caráter sociopsicológico e outra decorrente da racionalidade, sendo que ambas são complementares.

Nesse caso, a adoção de tecnologia depende de algumas características pessoais dos produtores, como: idade, educação, sociabilidade, cosmopolitismo, adesão ao novo e capacidade para assumir riscos. Ao mesmo tempo, a adesão à tecnologia também está vinculada à racionalidade do uso e da combinação de fatores econômicos envolvidos no empreendimento agropecuário.

Para Pomeranz (1985), a racionalidade na aplicação dos recursos deve se dar através da conjugação mais adequada de meios para a obtenção de certos fins. Ou seja, é necessário, na atividade econômica, buscar o máximo resultado com um dado montante de recursos ou minimizar este montante tendo em vista um dado resultado, mas sabendo que isso não se apresenta em ambiente neutro, pois depende de uma configuração histórico-social determinada. O planejamento mostra-se, então, como uma medida analítica que antecipa o curso de uma ação e as análises, realizadas na perspectiva "exante", tendem a racionalizar a aplicação de recursos privados e públicos.

A racionalidade prezará por um determinado nível de retorno do investimento, seja ele capital, conhecimento e/ou trabalho, que terá maiores chances de ocorrer dependendo da acurácia do plano a ser executado. Dentre as distintas formas de planejamento, a análise de projetos constitui-se uma ferramenta bastante útil para tomada de decisão sobre o investimento. 
Segundo Noronha (1987), a importância da análise de projetos ultrapassa os limites da empresa rural, podendo se adequar a outros níveis, como a projetos de investimento de comunidades e a planos nacionais de desenvolvimento.

Mesmo que a decisão de investimento seja de uma única empresa, ela é fundamental para o funcionamento do sistema econômico, pois o comportamento de relevantes variáveis macroeconômicas depende da decisão individual de milhares de investidores, segundo Silva Neto (1999), acentuando-se, assim, a relevância das técnicas de análises de projetos.

\subsection{A avaliação de projetos}

A elaboração e a análise de projetos, geralmente, são realizadas sob uma perspectiva "ex-ante", ou seja, são processos, anteriores à implementação e efetivação dos projetos, que têm a função de gerar um conjunto de informações que subsidiem a tomada de decisões orientada sempre no sentido de maximizar o resultado desejado.

Sob a ótica econômica, o lucro, propriamente monetário, é posicionado como o principal objetivo a ser atingido de acordo com a teoria econômica da produção, pois é o principal fator que determina os níveis de utilidade do tomador de decisões. Entretanto, Ambrósio (1997), através de uma revisão literária, enfatiza que os tomadores de decisão buscam a otimização de múltiplos objetivos, fazendo com que o lucro deixe de ser o atributo supremo. Isso porque, se os critérios sócio-ambientais forem adicionados, a melhoria da qualidade de vida e a redução do desperdício podem passar a ser considerados como prioridades.

Esses critérios podem ser abordados em uma única unidade produtora e assumem um grau maior de relevância quando são associados com perspectiva mais globais. Entretanto, a transição do individual para o global não pode ser considerada @mo uma questão simples, conforme a idéia implícita na citação de Contador (1981): "na prática, os projetos são elaborados sem que estejam integrados em plano global, e, por sua vez, os planos globais não são suficientemente detalhados ao nível de projetos".

Outra questão inerente às técnicas voltadas à análise de projetos econômicos é a validade das avaliações frente às incertezas das projeções futuras. Segundo Neves 
(1984), as expectativas baseadas em critérios gerados nas condições de certeza raramente serão verificadas na prática, principalmente quando o horizonte de tempo do projeto é longo; neste caso, mais aleatórios se tornarão os juízos ou as previsões de preços ou produtividade.

Evidentemente, o projeto deve evitar ao máximo os erros nas etapas de elaboração e projeção, mas, por mais perfeita que seja a engenharia do projeto, é necessário reconhecer a incerteza intrínseca e, ao mesmo tempo, estimar o grau de incerteza e risco do investimento, conforme ressalta Buarque (1991). Por isso a introdução do risco nas análises econômicas permite contornar as deficiências do ambiente da certeza.

\subsection{A incorporação do risco em análises econômicas}

$\mathrm{Na}$ literatura econômica é possível notar que existem diferenças conceituais sobre as terminologias que denotam o risco e a incerteza. Segundo Knight (1972), o risco está associado a comportamentos aleatórios dos quais se tem conhecimento e que podem ser previsíveis dentro de uma margem de erro, enquanto que a incerteza está ligada a eventos imprevisíveis, sobre os quais não há informações suficientes para associá-las a uma estrutura comportamental.

Do ponto de vista pragmático, o tratamento de ambas as situações exige o uso da teoria de probabilidades e os conceitos passam a ser utilizados de forma indiferente ou complementar. Cruz (1984) reforça essa idéia de complementaridade ao lembrar que, na agricultura, a disponibilidade de dados não permite um tratamento assintótico de probabilidades. Assim, o conceito de risco não é consolidado; simultaneamente, os agentes têm uma idéia subjetiva do que seja mais provável, ou seja, a incerteza não é absoluta.

Martines Filho \& Peres (1998) comentam que existem três importantes formas de incorporar risco em análises econômicas: i) através da "análise de decisão", um instrumental estatístico bastante genérico que utiliza as árvores ou, de forma alternativa, os diagramas de decisão; ii) através do "enfoque da Média-Variância"; e iii) através da 
técnica de Simulação de Monte Carlo, que pode ser empregada em diversas situações de conhecimento imperfeito.

A análise de decisão mencionada no parágrafo anterior baseia-se na teoria de decisão de Bernoulli que agrega ao processo de tomada de decisões as condições de risco. Segundo Dillon ${ }^{2}$ (1971), citado por Cruz (1984), a teoria é normativa e fundamenta-se nas probabilidades subjetivas de um tomador de decisão a respeito de suas preferências pessoais tendo em vista a ocorrência de eventos incertos. Os axiomas envolvidos nessa teoria, descritos por Neumann e Morgenstern, apresentados em Dhumul (1977). Quando não-violados, permitem a existência de uma função de utilidade de um tomador que associa um único índice de utilidade a um evento incerto.

Cruz (1984) cita que o excessivo grau de generalidade do teorema fundamental da teoria da utilidade de Neumann e Morgenstain dificulta a sua aplicação empírica e diversas são as tentativas que buscam operacionalizar esse teorema.

Segundo Hillier (1980), as árvores de decisões são instrumentos poderosos para se determinar um curso ótimo de ação a ser seguido pelo tomador de decisão. Mas, para que isso seja consolidado, é necessário enumerar, de forma gráfica e cronológica, todos os cursos de ação disponíveis. Em muitos casos, a escolha associada apenas aos termos monetários não leva em consideração as consequiências de se realizar a ação escolhida. Por isso, o tomador deverá expressar sua utilidade e qualificar suas probabilidades subjetivas diante de cada ação. Para isso, utiliza-se a "escala de utilidade", sendo que os valores monetários são transformados numa escala apropriada que reflete as preferências e o grau de aversão ao risco do tomador de decisão.

O modelo de Média-Variância desenvolvido por Markowitz, Tobin e Feldstein a partir da teoria de Bernoulli (Contini, 1984), visa incorporar a um valor esperado a dimensão de variabilidade desse valor; presume-se, então, que o tomador de decisão escolha a alternativa que tenha a menor variância para uma mesma média ou a maior média para uma mesma variância.

\footnotetext{
${ }^{2}$ DILLON, J.L.; SCANDIZZO, P.L. Risk attitudes of subsistence farmers in North East Brazil: a sampling approach. American Journal of Agricultural Economic, v.60, n.3, p.425-435, Aug. 1978.
} 
Azevedo Filho (1988) apresenta o enfoque da Esperança-Variância como um critério de decisão bastante prático, mas que pode estar sujeito a contra-exemplos que induzem a interpretações errôneas.

Contini (1984) descreve o risco como algo subjetivo, inerente a cada tomador de decisão, fato que dificulta a obtenção das funções de utilidade de cada indivíduo, conforme exige o princípio de Bernoulli. Uma solução destinada a contornar tal problema advém das regras de dominância estocástica, levando-se em consideração toda a distribuição cumulativa de probabilidade dos retornos, ao invés simplesmente da média e da variância (Contini, 1984; Cruz, 1984).

Com relação à simulação de Monte Carlo, Martines Filho \& Peres (1998) a definem como um método eficaz que pode ser usado em vários tipos de problemas de decisão, em cenários de conhecimento imperfeito e em problemas complexos na qual a solução analítica é difícil ou impossível.

Segundo Noronha (1987), o método de Monte Carlo é o mais simples do ponto de vista prático, tendo em vista as discussões teóricas sobre as frmas de se agregar as probabilidades e as maneiras de se avaliar os resultados nas análises de risco. Os trabalhos mais aplicados são aqueles difundidos pelas publicações do Banco Mundial.

Uma dessas discussões, descrita por Reutlinger (1984), compara dois métodos. Um deles constrói as distribuições factuais das probabilidades dos indicadores de retorno (Taxa Interna de Retorno, Valor Presente Líquido) utilizando um grande número de repetidas amostras simuladas que respeitam as probabilidades estimadas de cada variável e as restrições de independência entre elas; o outro procura calcular a média e a variância dos indicadores de desempenho, mas interpreta os seus resultados em termos de uma distribuição normal aproximada. A análise desses métodos permite concluir que existem vantagens e desvantagens nos dois tipos de procedimentos e que o primeiro se assemelha com o próprio método de Monte Carlo e é preferível quando se pretende realizar uma avaliação completa de probabilidades.

Além dessas formas de incorporação de risco, existem outros modelos que auxiliam o processo de tomada de decisões, mas são mais apropriados para o planejamento de uma propriedade rural como um todo. Nesse contexto encaixam-se os 
modelos, derivados da ampliação do enfoque Média-Variância, que procuram minimizar o risco sujeito a um determinado lucro ou maximizar o lucro para um risco prédeterminado, utilizando-se para isso de variações na combinação das atividades que estão presentes numa propriedade rural. A utilização empírica do modelo proposto por Markowitz (1952) e por Hazell (1971) - Minimization of Total Absolute Deviation MOTAD - pode ser avaliada nos trabalhos de Peres (1984) e de Azevedo Filho \& Peres (1984), respectivamente. 


\section{MATERIAL E MÉTODOS}

Para buscar os objetivos relacionados à avaliação econômica, declarados anteriormente, foram utilizados os procedimentos empregados nas técnicas de análise de projetos, incluindo algumas análises relacionadas æ̀ condições de incerteza.

Neste estudo são avaliadas seis situações distintas: duas técnicas de recuperação direta e duas de recuperação indireta ${ }^{3}$, sendo que as quatro técnicas, discriminadas no subitem 3.3.2 constituíram quatro projetos independentes. Um quinto projeto, considerado testemunha, teve por objetivo mensurar a rentabilidade da propriedade caso nada seja feito, mantendo o sistema de produção sem alterações.

Cabe ainda ressaltar a importância de um sexto sistema de produção que, devido a sua relevância ambiental, também foi considerado como um projeto alternativo. Refere-se à opção que um produtor tem em utilizar o capital financeiro - montante dos recursos a serem despendidos no processo de recuperação de pastagens somado ao que está imobilizado em sua propriedade - para a compra de terras com áreas florestais nativas a fim de efetuar o desmatamento e abrir novas áreas de pastejo.

Para situar as ações que envolvem esse estudo, optou-se por apresentar a sistemática operacional da pesquisa através de um fluxo, apresentado na Figura 1, cujos procedimentos relativos à coleta de informações necessárias à pesquisa e os métodos que foram empregados na condução da avaliação econômica estão explicitados nos itens a seguir.

\footnotetext{
${ }^{3}$ Conceitualmente, o termo recuperação pode ser dividido em recuperação direta ou indireta e renovação direta ou indireta, como é apresentado por Aguiar (1998). Os processos diretos utilizam apenas operações mecânicas e/ou químicas e os indiretos vinculam essas operações ao consórcio com lavouras agrícolas. No caso da recuperação, a espécie forrageira é mantida, enquanto que, na renovação, há a substituição da antiga por outra.
} 


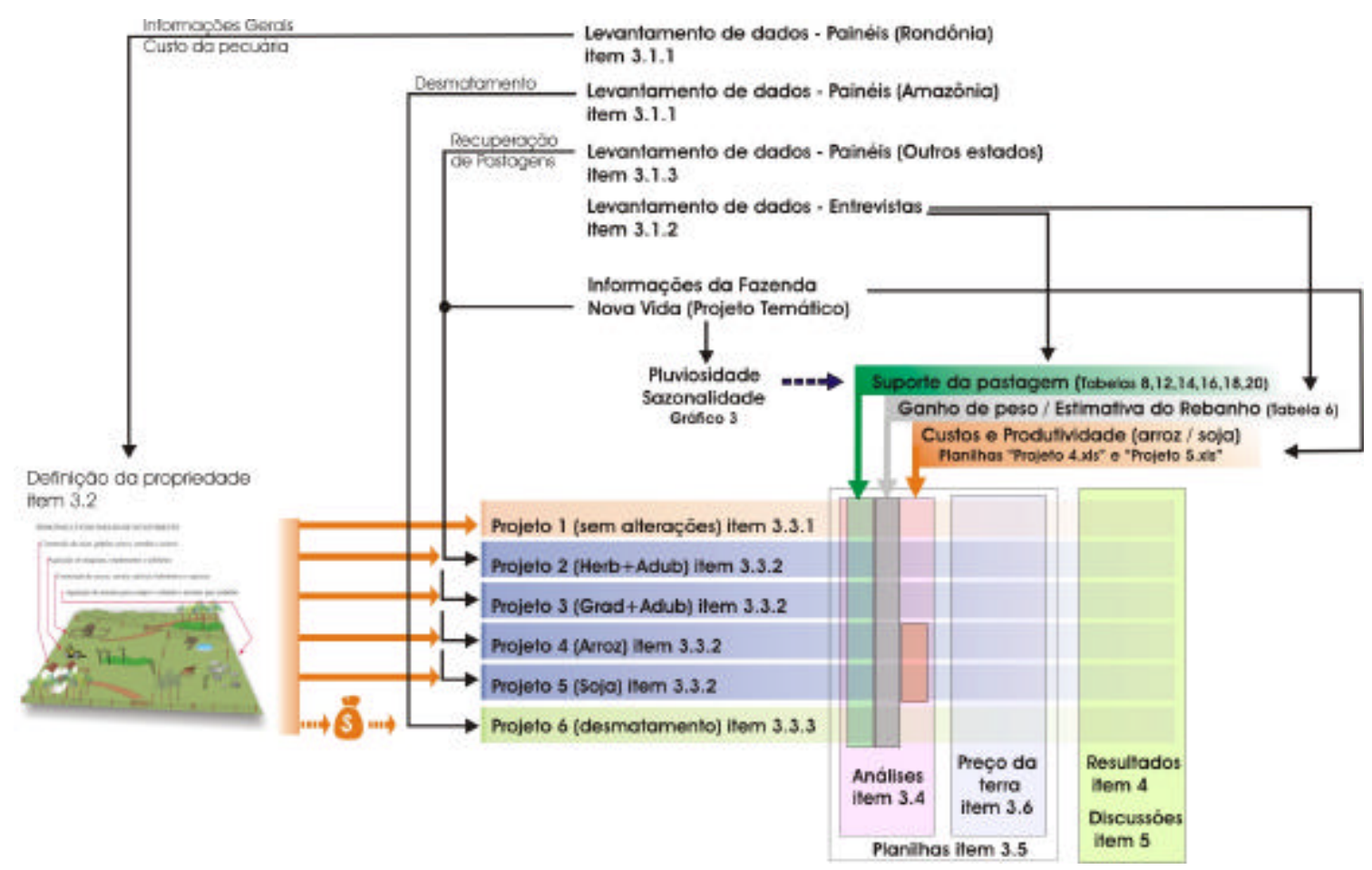

Figura 1 - Sistemática operacional da pesquisa.

\subsection{O levantamento de dados primários}

O estudo tem como enfoque principal a Fazenda Nova Vida - município de Ariquemes - onde as parcelas experimentais do projeto temático (apresentado com mais detalhes no Anexo C - compact $\operatorname{disc}^{4}$ ) foram desenvolvidas. Nesse contexto, ressalta-se o fato de que a obtenção precisa dos dados inerentes às variáveis ambientais e agronômicas demanda alto empenho tecnológico e, por esse motivo, as áreas utilizadas no experimento são bastante reduzidas em relação às reais destinadas à produção regional. Adicionando a esse aspecto a teoria da economia de escala, amplamente descrita na literatura econômica, denota-se que os custos e a produtividade das áreas experimentais diferem daqueles voltados exclusivamente à produção, devido à ineficiência da otimização de serviços e máquinas.

Para reduzir esse problema que diferencia os custos de pequenas áreas experimentais daquelas de proporções maiores e, na tentativa de aproximar o estudo à

\footnotetext{
${ }^{4}$ Todos os anexos citados estão no compact disc que acompanha este trabalho.
} 
realidade regional, foi necessário associar os dados experimentais às informações locais de propriedades envolvidas com a atividade pecuária. Para tanto, executou-se um conjunto de etapas para realizar o levantamento dos dados necessários às análises, explicitadas nos subitens a seguir.

\subsubsection{Levantamento de dados primários através de painéis}

Embora a caracterização ambiental e agronômica tenha sido realizada em Ariquemes, região centro-norte de Rondônia, a avaliação econômica desse trabalho visa fazer inferências para a região em geral. Infelizmente, o caráter de uma análise regional representativa com uma base censitária, tornaria a tarefa de obtenção precisa dos dados de diferentes propriedades e sistemas de produção bastante complexa e de certa forma, impraticável - frente as circunstâncias atuais e do ponto de vista dos custos envolvidos. Em razão da grande heterogeneidade gerada pela área física das propriedades, tamanho do rebanho, sistemas de produção, nível de tecnificação e formas de gerenciamento, o uso de amostras representativas também seria bastante dificultado e oneroso.

$\mathrm{Na}$ tentativa de mitigar essa questão e, ao mesmo tempo, aproximar esse estudo às peculiaridades locais, optou-se por utilizar a técnica de levantamento de dados primários denominada Painel, que possibilitou a formalização de uma propriedade que melhor representasse as existentes na região, dentro dos padrões modais do universo considerado.

\subsubsection{O Painel}

Esse método tem sido utilizado em diversos estudos que buscam a obtenção de dados primários, pode-se citar como exemplos: Coble et al. (1996) que analisaram o modelo de seguro agrícola nos EUA e, no Brasil, De Zen (2002), que estimou fronteiras de eficiência na agricultura.

O Painel é um procedimento de custo bastante baixo, quando comparado ao levantamento censitário de unidades de produção agrícolas; proporciona, também, maior agilidade e versatilidade sem comprometer a qualidade das informações, mas não permite realizar inferências estatísticas, devido ao reduzido tamanho amostral. 
A técnica é descrita como sendo uma reunião que agrega um grupo de pessoas, do qual tomam parte: um ou mais pesquisadores, um técnico regional e um grupo formado por 5 a 9 agricultores envolvidos com a atividade em questão.

As reuniões são marcadas com antecedência, utilizando-se de contatos com empresas privadas, associações e sindicatos regionais ou órgãos de fomento a pesquisa. Quando iniciada, os temas e os números que foram determinados previamente, em entrevistas com os técnicos locais, são debatidos com os produtores rurais. Para que todos os participantes interajam, utiliza-se um computador portátil e um aparelho destinado a projetar planilhas previamente elaboradas, destinadas a facilitar a inserção dos dados e a promoção de algumas análises imediatas - as planilhas foram desenvolvidas utilizando os recursos do aplicativo Microsoft - Excel 2000.

Cada coeficiente técnico, dose, quantidade, preço e frequiência de uso dos fatores presentes na planilha são apresentados e questionados. O debate gerado determina a coerência das informações através da concordância ou não dos produtores rurais.

Com isso, os números resultantes do painel (índices de produtividade, custos de implantação, astos operacionais) tendem a se aproximar da realidade regional, pois são gerados através das entrevistas com técnicos locais e validados ou ratificados por meio do consenso dos produtores presentes na reunião.

Entretanto, salienta-se que os índices e custos declarados por cada participante não foram relacionados com as suas respectivas propriedades, mas sim, com uma única, declarada no início de cada painel como aquela que representa melhor o tamanho e o sistema de produção da maioria das propriedades locais.

\subsubsection{Localização das regiões de coleta de informações}

A primeira fase de execução de um painel depende da definição do local onde será realizado. Geralmente, os locais escolhidos são aqueles onde o potencial da atividade a ser estudada é maior.

Através do levantamento de dados do Instituto Brasileiro de Geografia e Estatística - IBGE, demonstrado na Tabela 1 foi possível verificar como estão distribuídas, no estado de Rondônia, as produções de maior interesse para esta pesquisa 
- bovinocultura de corte, arroz e soja - conforme a descrição dos sistemas apresentados no subitem 3.3.2.

Tabela 1. Valores percentuais da produção de arroz, soja e do rebanho bovino por microrregiões.

\begin{tabular}{lcccc}
\hline Microrregião Geográfica & $\begin{array}{c}\text { Efetivo do } \\
\text { rebanho }\end{array}$ & $\begin{array}{c}\text { Produção de } \\
\text { Soja }^{2}\end{array}$ & $\begin{array}{c}\text { Produção de } \\
\text { Arroz }^{2}\end{array}$ & $\begin{array}{c}\text { Estado de Rondônia } \\
\text { Divisão por microrregiões (IBGE) }\end{array}$ \\
\hline 1- Ji-Paraná & $28,80 \%$ & & $15,14 \%$ \\
2- Cacoal & $22,77 \%$ & & $21,92 \%$ \\
3- Ariquemes & $11,45 \%$ & & $9,70 \%$ \\
4 Vilhena & $10,64 \%$ & $70,40 \%$ & $10,94 \%$ \\
5- Colorado do Oeste & $10,59 \%$ & $29,60 \%$ & $23,93 \%$ \\
6- Porto Velho & $7,51 \%$ & & $6,02 \%$ \\
7- Alvorada D'Oeste & $6,51 \%$ & & $9,75 \%$ \\
8- Guajará-Mirim & $1,73 \%$ & & $2,61 \%$ & \\
\hline
\end{tabular}

Fontes: ${ }_{2}^{1}$ IBGE (2001a)

Observando a Tabela 1 nota-se que a região central do estado concentra a maior parte da pecuária - as microrregiões de Ji-Paraná e Cacoal agregam a metade do rebanho do estado - e as regiões centro-sul e sudeste detêm a maior parcela das produções de arroz e soja; em especifico, a soja é produzida apenas nas regiões de Vilhena e Colorado do Oeste. Em vista dessas observações, o levantamento das informações relacionadas à pecuária foi desenvolvido no município de Ji-Paraná, agregando alguns pecuaristas de Cacoal, e no caso dos grãos (soja e arroz), os dados foram obtidos na região de Vilhena, por concentrar a maior parte da produção de soja e ter uma parcela da cultura do arroz.

\subsubsection{Levantamento de dados de outras áreas referentes à Região Amazônica}

Para buscar informações necessárias à compreensão da dinâmica do processo de interação da pecuária de corte com o desmatamento e a floresta, não apenas na região rondoniense, mas também em toda a região amazônica, foram realizados painéis (na mesma linha do procedimento descrito no item anterior) e pesquisas nas instituições locais presentes nos estados do Pará e do Mato Grosso. As regiões escolhidas nesses 
estados correspondem àquelas que possuem rebanhos bovinos bastante representativos e ao mesmo tempo estão situadas nas áreas da atual fronteira de desmatamento.

A Figura 2 e Figura 3 derivam da sobreposição das áreas de grande expressão para o setor pecuário com os mapas das áreas florestais obtidos através do Programa de Monitoramento de Queimadas e Prevenção e Controle de Incêndios Florestais no Arco do Desflorestamento na Amazônia do Instituto Nacional de Pesquisas Espaciais (PROARCO - INPE).

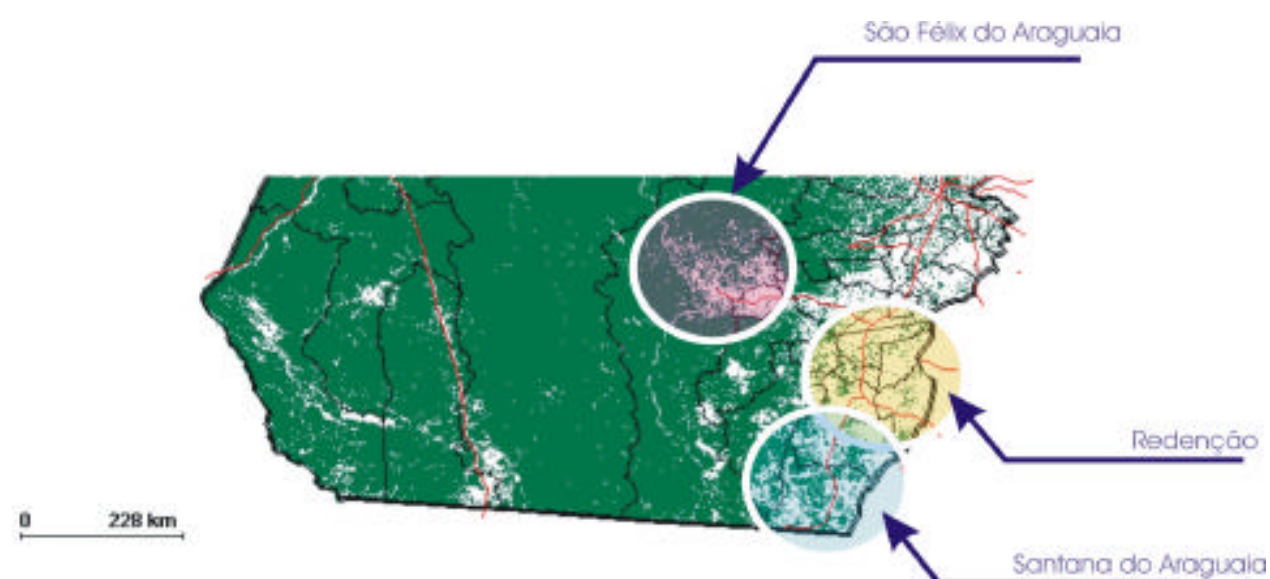

Figura 2 - Desflorestamento e áreas importantes para a pecuária: sul do Estado do Pará. Fonte: Adaptado de INPE (1999)

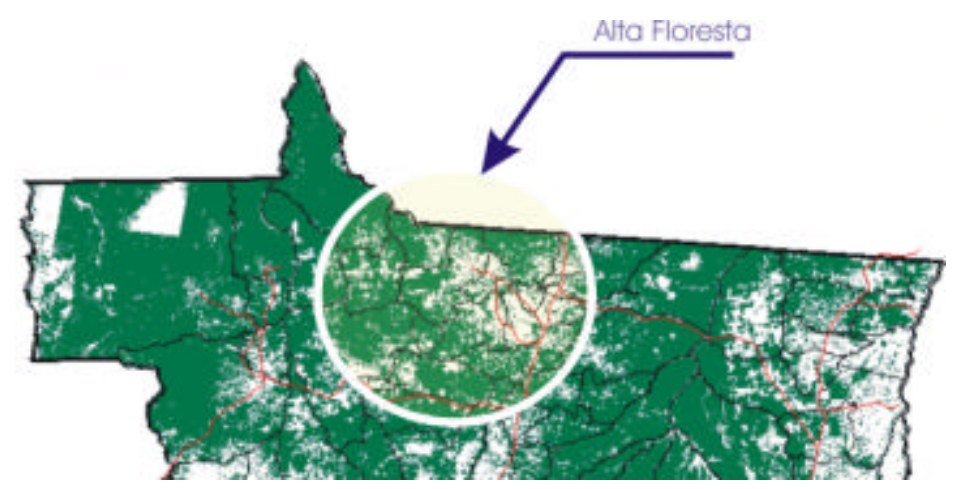

Figura 3 - Desflorestamento e áreas importantes para a pecuária: norte do Estado do Mato Grosso.

Fonte: Adaptado de INPE (1999)

No estado do Pará o levantamento de dados se deu nas regiões de Santana do Araguaia, Redenção e Paragominas, enquanto que no estado do Mato Grosso, as 
informações referem-se à região de Alta Floresta. Com exceção de Paragominas, todas as regiões estão dentro de áreas de fronteira, onde as ações de desmatamento ainda são intensas.

Os dados obtidos nessas regiões foram bastante úteis para a estruturação do sexto sistema, na qual o tomador de decisão optaria por se desfazer da propriedade e investiria em uma nova área com intuito de desmatá-la.

\subsubsection{Levantamento de dados primários através de entrevistas}

Algumas informações necessárias a essa pesquisa não puderam ser obtidas através do método anterior, pois no painel são captados os dados das atividades e operações que são normalmente realizadas pelos produtores e isso dificulta a obtenção de índices referentes a um novo sistema produtivo, cuja tecnologia seja recente para a região estudada. Muitas vezes, é possível reunir, isoladamente, um grupo de técnicos e produtores que adotam sistemas mais avançados, nestes casos existe a possibilidade de captar e avaliar os ganhos obtidos com o uso de novos pacotes tecnológicos.

Segundo as informações obtidas através dos painéis, m estado de Rondônia e na região norte do Mato Grosso, o uso das técnicas de recuperação de pastagens ainda não é um hábito frequiente, especialmente, no que diz respeito à integração lavoura e pastagem (ILP), por isso não foi possível organizar painéis específicos para esse assunto ${ }^{5}$; na região rondoniense. Apenas os painéis referentes à pecuária tradicional puderam ser efetivados. A complementação das informações foi obtida através de entrevistas com técnicos, pesquisadores e empresas voltados ao ramo agropecuário da região.

O Quadro 1 apresenta as fontes consultadas para a pesquisa, nos três estados da região amazônica, com o intuito de complementar as informações obtidas nos painéis e no experimento desenvolvido pelo projeto temático.

Desse tipo de pesquisa, derivaram os dados para a melhor compreensão dos sistemas de produção e os fatores que determinam a sua produtividade. A abordagem

\footnotetext{
5 Isso está associado ao fato de que as áreas pastoris são relativamente novas, ou seja, a colonização iniciou-se a pouco mais de três décadas, e a maioria das áreas de pastagens ainda não se apresentam em avançado grau de degradação, como pode ser observado em algumas regiões de GO e MS.
} 
das instituições locais visou também a itens como: o processo de colonização, o desenvolvimento tecnológico, a interação da pecuária com outras atividades, os fatores climáticos e edáficos e a comercialização de produtos agropecuários. Esses aspectos têm a finalidade de complementar o estudo facilitando o entendimento do sistema socioeconômico local.

\begin{tabular}{|cl|}
\hline Estado & \multicolumn{1}{c|}{ Fontes de informação } \\
\hline & Fundo Emergencial de Febre Aftosa do Estado de Rondônia (FEFA-RO) \\
& Instituto Nacional de Colonização e Reforma Agrária (INCRA) \\
Empresa Brasileira de Pesquisa Agropecuária Rondônia (EMBRAPA-RO) & $\begin{array}{l}\text { Lojas de comercialização de produtos agropecuários } \\
\text { Representantes de vendas de empresas de produtos agropecuários }\end{array}$ \\
& Sindicato Rural de Alta Floresta \\
\hline MT & EMBRAPA Amazônia Oriental \\
& Fundo de Desenvolvimento da Pecuária no Estado do Pará (Fundepec -PA) \\
& Sindicato Rural de Redenção \\
\hline
\end{tabular}

Quadro 1 - Fontes de informação - RO, MT, PA.

\subsubsection{Levantamento de dados de outras importantes regiões para a pecuária de corte}

Embora seja necessário, em muitas regiões da Amazônia Legal, a recuperação de pastagens ainda não é uma prática muito adotada. É bastante provável que essa característica decorra do fato de que as áreas de pastagem são, relativamente, novas. Em apenas dois dos seis painéis realizados na região amazônica, foi mencionada a necessidade da recuperação das pastagens degradadas ${ }^{6}$.

De forma a corroborar essa hipótese, apenas em Paragominas e Redenção (nordeste e sudeste do Pará, respectivamente), regiões onde a colonização iniciourse em

\footnotetext{
${ }^{6}$ Segundo Nascimento Junior (1994), a pastagem é considerada degradada quando há uma grande diferença negativa entre a produtividade que apresenta e a que lhe é potencial para as condições edafoclimáticas e bióticas a que está submetida. Frente a essa definição, é possível averiguar a importância das técnicas de recuperação de pastagens nas propriedades dedicadas à pecuária, quando o tempo de uso da pastagem, sem a reposição de nutrientes, permeia por muitos anos. Obviamente, fatores intrínsecos a uma propriedade, não a região como um todo, condicionados aos tipos de solos e as práticas de manejo incorreto da pastagem, podem determinar a adoção das práticas de reabilitação mais precocemente. Por isso é natural que em diversas regiões da Amazônia existam propriedades com este tipo de problema, independente da época de colonização.
} 
meados da década de 1960, foi notada a necessidade dos procedimentos de reabilitação da pastagem. Em locais de colonização mais recente como Ji-Paraná - RO e Alta Floresta - MT, essas práticas ainda não são muito comuns, conforme o que pôde ser observado na execução dos painéis.

De acordo com Arruda \& Sugai (1994), taxas geométricas elevadas de crescimento do rebanho bovino ocorreram a partir de 1975, na região Amazônica, enquanto que em outras regiões do país, o crescimento foi pouco expressivo ou negativo. Ainda segundo esses autores: "As áreas de mata e de cerrado nos estados do Pará, Rondônia e Acre, sofreram derrubadas com avanços nos sentidos: (a) Goiás, leste do Pará e Oeste do Maranhão, (b) Goiás, leste do Mato Grosso e sul do Pará; (c) Mato Grosso do Sul, Oeste do Mato Grosso, Rondônia Acre e sul do Amazonas". Com base nessa afirmação nota-se que os estados de Mato Grosso do Sul e Goiás foram as regiões por onde a pecuária inicialmente começou a se expandir no sentido amazônico, conforme a Figura 4.

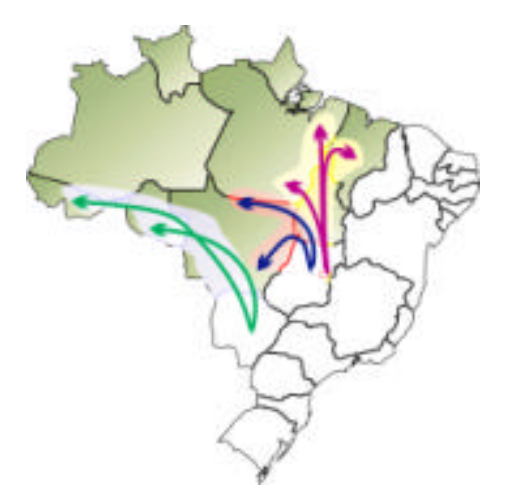

Figura 4 - Avanço da pecuária nas últimas décadas.

Fonte: Mapa adaptado segundo Arruda \& Sugai (1994)

Mesmo que este estudo não tenha foco nesses dois estados, é bastante válido o entendimento das questões que envolvem o desenvolvimento da pecuária de corte extensiva e da agricultura, na região centro-oeste, pois elas permitem auxiliar a compreensão da dinâmica do uso do solo. Nesses estados, de grande relevância para a pecuária no âmbito nacional ${ }^{7}$, nota-se que a adoção das técnicas de recuperação de

\footnotetext{
${ }^{7}$ Segundo os dados do IBGE (2001a) os estados de Mato Grosso do Sul e Goiás possuem o primeiro e o segundo maior rebanho efetivo do País, respectivamente.
} 
pastagens já são comumente empregadas e por isso, as informações extraídas dessas duas regiões trazem grande subsídio às análises dos projetos que contém os sistemas de reabilitação dos pastos. Em meio a essas justificativas também foram utilizados os resultados dos painéis realizados pelo Centro de Estudos Avançados em Economia Aplicada - Escola Superior de Agricultura Luiz de Queiroz / Universidade de São Paulo (Cepea - Esalq / USP) nos estados do Mato Grosso do Sul e de Goiás, a fim de formar um banco de dados necessário para embasar algumas análises sobre a pecuária extensiva e, conseqüentemente, o uso da pastagem.

Para formar esta base de dados foram utilizadas as informações de 12 municípios no Mato Grosso do Sul e seis em Goiás, onde foram realizados os painéis. Os critérios para a escolha dessas regiões levaram em consideração: a importância do município para a pecuária estadual, a diversidade das tecnologias empregadas e os sistemas de produção predominantes. Através do mapa da Figura 5 é possível localizar todos os municípios que foram envolvidos neste estudo.

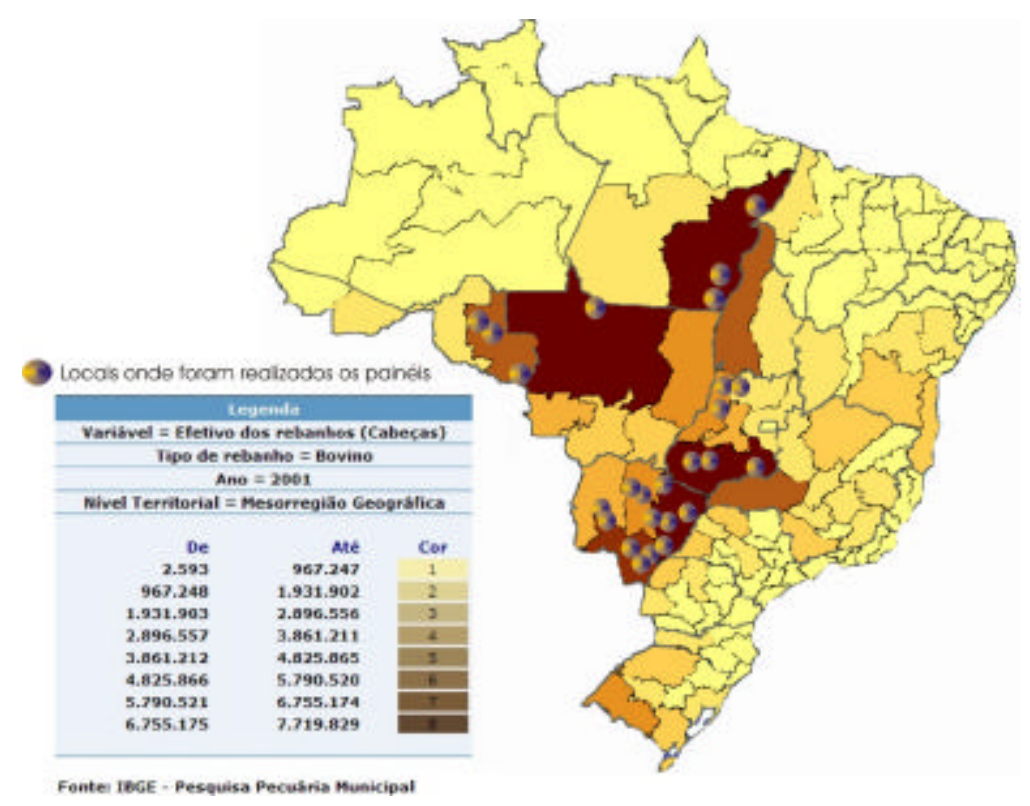

Figura 5 - Disposição dos municípios onde foram realizados os painéis.

Fonte: Adaptado de IBGE (2001a) 
Em todos os painéis mencionados, ros 5 estados, foram consultados ao todo 162 produtores rurais, voltados à atividade pecuária, em 24 painéis, com média de 7 integrantes por reunião. Além disso, cada reunião foi composta, além dos produtores, com o efetivo de no mínimo um técnico local e de dois pesquisadores.

O escopo de todos os painéis foi determinar os custos envolvidos na produção pecuária incluindo os gastos relativos às pastagens. Buscou-se determinar através do consenso do grupo a estrutura fundiária e a infra-estrutura das propriedades regionais; a densidade e o padrão racial de bovinos; os índices de produtividade zootécnica; o custo das operações empregadas na recuperação das pastagens; as dosagens, freqüências de compra e os preços de todos os insumos utilizados.

Os quadros presentes no Anexo A apresentam de forma bastante resumida as principais informações que descrevem os sistemas produtivos pecuários analisados em cada uma das regiões. É necessário lembrar que apenas os dados, referentes à propriedade representativa do painel de Ji-Paraná, foram usados nas análises deste trabalho. As informações das outras regiões foram utilizadas como suporte, de forma a embasar as variações de produtividade e produção decorrentes de cenários gerados pela implementação dos quatro sistemas de recuperação propostos, aos quais foi submetida a propriedade representativa.

Além das informações dos painéis dirigidos à bovinocultura, também foram obtidos e analisados os custos e produtividades dos cultivos de soja e arroz, realizados na região de Rondônia, e das parcelas experimentais desenvolvidas pelo projeto temático.

\subsection{A definição de uma propriedade típica}

Através do painel realizado na região de Ji-Paraná, pôde ser caracterizada uma propriedade típica na qual se desenvolve a pecuária tradicional. Esse estabelecimento foi utilizado como padrão para todos os seis projetos que envolvem esta pesquisa e tem como características principais os valores apresentados na Tabela 2 e Tabela 3. 
Tabela 2. Características gerais da propriedade representativa.

\begin{tabular}{ll}
\hline \multicolumn{1}{c}{ Característica } & \multicolumn{1}{c}{ Descrição } \\
\hline Área total & 1452 hectares \\
Área de pastagem & 726 hectares \\
Área utilizada por construções e benfeitorias + Reserva Legal & 726 hectares \\
Área para cultivos agrícolas & 0 hectare \\
Sistema de produção pecuário & Cria-recria-engorda \\
Quantidade de pastagem recuperada por ano & 0 hectare \\
Tipo de pastagem predominante & Brachiaria Brizantha \\
\hline
\end{tabular}

Fonte: Dados da pesquisa.

Tabela 3. Principais informações zootécnicas .

\begin{tabular}{ll}
\hline \multicolumn{1}{c}{ Informações } & \multicolumn{1}{c}{ Descrição } \\
\hline Taxa de lotação em UA/ha (média anual)* & 1,05 \\
Taxa de lotação em cabeças/ha (média anual) & 1,63 \\
Raça predominante & Nelore \\
Taxa anual mortalidade - animais jovens & $3,00 \%$ \\
Taxa anual mortalidade - animais adultos & $1,30 \%$ \\
Média anual de ganho de peso - animais jovens & $570 \mathrm{gr} / \mathrm{dia}$ \\
Média anual de ganho de peso - animais adultos & $480 \mathrm{gr} / \mathrm{dia}$ \\
Relação vaca/touro & 20 \\
Intervalo entre partos (IEP) & $16 \mathrm{meses}$ \\
Taxa de parição média & $75 \%$ \\
$\%$ vacas descarte & $25 \%$ \\
Peso ao nascimento & $30 \mathrm{Kg}$ \\
Peso bezerro (desmamado aos 8 meses) & $180 \mathrm{Kg}$ \\
Peso bezerra (desmamada aos 8 meses) & $160 \mathrm{Kg}$ \\
Peso boi acabado para o abate & $471 \mathrm{Kg}$ \\
\hline
\end{tabular}

Fonte: Dados da pesquisa.

* - UA: Unidade Animal de $450 \mathrm{Kg}$

A área determinada pelos produtores no painel, 1452 hectares, para definir uma propriedade representativa de pecuária extensiva, situa-se dentro do padrão médio das propriedades existentes no estado. De acordo com a estratificação definida pelo IBGE, existem quantidades de propriedades parecidas para os grupos de 100 até 5000 hectares, todos variando na faixa de 10 a $12 \%$ de freqüência, conforme o Gráfico 1 . Por isso os 
resultados simulados para esse estabelecimento poderão ser significativos para uma parcela das propriedades do estado.

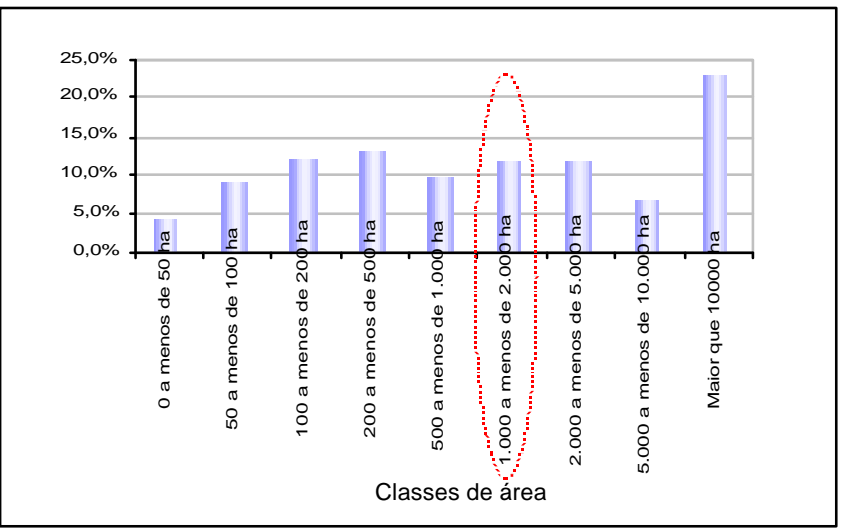

Gráfico 1 - Área dos estabelecimentos por grupo de atividade econômica (pecuária). Fonte: IBGE (1996)

Além das características apresentadas anteriormente, também foram orçados os itens necessários para a implementação da propriedade, de forma a estimar o capital imobilizado em construções, benfeitorias, máquinas, implementos, equipamentos e animais.

O patrimônio estimado total da propriedade, considerada como representativa, apresentou para o mês de julho de 2003 o valor de R\$ 1.850.000,00 distribuídos conforme o Gráfico 2.

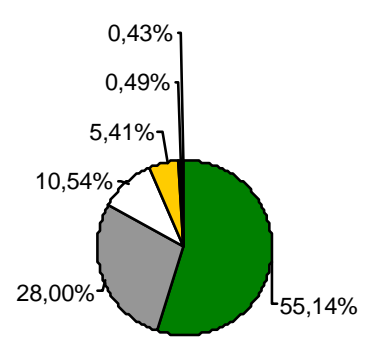

$\square$ Terra
$\square$ Rebanho Inicial

$\square$ Construções benfeitorias (casas, cercas, etc.)

पMaquinas (tratores, utilitários, etc.)

Implementos (grades, roçadeiras, etc.)

Equipamentos (ferramentas, bombas, etc.)

Gráfico 2 - Percentual do capital investido na propriedade representativa.

Fonte: Dados da pesquisa. 


\subsection{Descrição dos projetos envolvidos}

Nos subitens a seguir estão listadas as considerações acerca de cada projeto, mas antes é necessário esclarecer algumas colocações que foram utilizadas como base na formulação dos valores relacionados àquantidade de área a ser recuperada por ano e ao ganho de peso do gado de acordo com a sazonalidade das chuvas.

Para determinar a quantidade de pastagem que um produtor irá recuperar por ano, optou-se por utilizar todos os dados provenientes dos painéis realizados nos estados de MS, GO, PA, RO e MT. Essa medida foi necessária visto que este valor não pode ser obtido no painel de RO, pois a recuperação ainda não é praticada comumente. A Tabela 4 demonstra os percentuais de área de pastagem que são, normalmente, recuperados pelos produtores.

Tabela 4. Percentuais de área da pastagem recuperada por ano.

\begin{tabular}{|c|c|c|c|c|}
\hline $\begin{array}{l}\text { Local } \\
\text { Estado e Município } \\
\text { GOCatalão }\end{array}$ & $\begin{array}{c}\begin{array}{c}\text { Área Total } \\
\text { (ha) }\end{array} \\
400\end{array}$ & $\begin{array}{c}\begin{array}{c}\text { Área de } \\
\text { pastagem (ha) }\end{array} \\
300\end{array}$ & $\begin{array}{l}\text { Área pastagem } \\
\text { recuperacão (ha) } \\
30\end{array}$ & $\begin{array}{l}\begin{array}{l}\text { Porcentagem da área } \\
\text { recuperada porano }\end{array} \\
10 \%\end{array}$ \\
\hline GO Jataí & 600 & 480 & 48 & $10 \%$ \\
\hline GO Nova Crixás & 1500 & 1200 & 120 & $10 \%$ \\
\hline GO Porangatu & 1000 & 700 & 80 & $11 \%$ \\
\hline GO Rio Verde & 387 & 310 & 62 & $20 \%$ \\
\hline GO São Miguel do Araguaia & 1000 & 800 & 80 & $10 \%$ \\
\hline PA Paragominas & 15488 & 5711 & 484 & $8 \%$ \\
\hline PA Redenção & 4840 & 2904 & 145 & $5 \%$ \\
\hline PA Santana do Araguaia & 3194 & 2904 & & \\
\hline MS Amambaí & 726 & 580 & 29 & $5 \%$ \\
\hline MS Brasilândia & 1210 & 1210 & & \\
\hline MS Bonito & 1500 & 750 & & \\
\hline MS Camapuã & 500 & 350 & & \\
\hline MS Chapadão do Sul (2) & 1000 & 700 & & \\
\hline MS Dourados & 1000 & 900 & 90 & $10 \%$ \\
\hline MS Naviraí & 2000 & 1600 & 160 & $10 \%$ \\
\hline MS Nova Andradina & 1815 & 1452 & 73 & $5 \%$ \\
\hline MS Miranda & 2000 & 1400 & 70 & $5 \%$ \\
\hline MS Paranaíba & 484 & 484 & 24 & $5 \%$ \\
\hline MS Ribas do Rio Pardo & 1000 & 750 & 100 & $13 \%$ \\
\hline MS São Gabriel do Oeste & 500 & 350 & 70 & $20 \%$ \\
\hline MT Alta Floresta & 1210 & 605 & & \\
\hline RO Ji-Paraná & 1452 & 726 & & \\
\hline Média & & & & $9,89 \%$ \\
\hline
\end{tabular}

Fonte: CEPEA (2003) ${ }^{8}$

\footnotetext{
${ }^{8}$ Custos de produção da pecuária em elaboração.
} 
$\mathrm{Na}$ maioria das regiões, as recomendações de especialistas determinam que é necessário recuperar cerca de $25 \%$ da área útil de pastagem, mas devido a fatores como: insuficiência de capital disponível para realizar as operações e a compra de insumos e animais para povoar o pasto, o risco da falta de chuvas após o semeio, e a necessidade de conhecimento técnico; a maioria dos produtores opta por recuperar faixas menores, ficando em torno da média de $10 \%$.

Tendo como hipótese que os produtores de Rondônia também seguirão o mesmo padrão do que foi observado nas outras regiões, daqui a alguns anos, foi estipulada a área de 73 hectares, ao ano, para recuperar a terra, haja vista que a propriedade anteriormente definida tem 726 hectares de área útil de pastagem.

Essa definição também determinou que o horizonte do projeto fosse feito para 8 anos, empo necessário para recuperar toda a área de pastagem passível de mecanização, cerca de $80 \%$ da área de pasto. Segundo as observações feitas pelos produtores, nos painéis em geral, muitas fazendas possuem pastagens com $20 \%$ ou mais de áreas com várzeas, afloração rochosa ou revelo acidentado; nesses locais existe o pasto e por isso não são áreas improdutivas, mas é impossibilitada a entrada de máquinas.

No espaço temporal de 8 anos é possível inserir os resultados de ganhos estimados com os procedimentos de reabilitação da terra, por exemplo: o uso da gradagem associada a adubação, segundo os técnicos entrevistados nos painéis, pode produzir ganhos até o quinto ano após a realização da operação, obviamente, em taxas decrescentes, mas significativas. Além disso, facilita a discussão dos benefícios com a valorização da terra, pois quando toda a área é trabalhada o valor patrimonial da propriedade será maior devido a transformação de áreas de pasto com tocos "resquícios" da queima da floresta - em áreas agricultáveis, devido as operações de enleiramento e gradagem da terra, presentes em três dos cinco projetos avaliados. Para horizontes acima de 8 anos, a área recuperada no primeiro ano seria novamente recuperada no nono ano, determinando um processo repetitivo para os anos subseqüientes, mantendo a constância fluxo de caixa e também do valor patrimonial da terra após o oitavo ano. Por tais motivos, elegeu-se o tempo de 7 anos a partir do ano zero (total de 8 anos), sendo igual em todos os projetos. 
Quanto às estimativas sazonais do ganho de peso dos animais, os cálculos foram embasados nas entrevistas com assessorias técnicas e produtores locais e nos parâmetros de pluviosidade. As médias mensais de precipitação, ao longo dos último dez anos, foram obtidas através das anotações cedidas pela Fazenda Nova Vida - local onde está instalado o experimento do Projeto Temático (Gráfico 3).

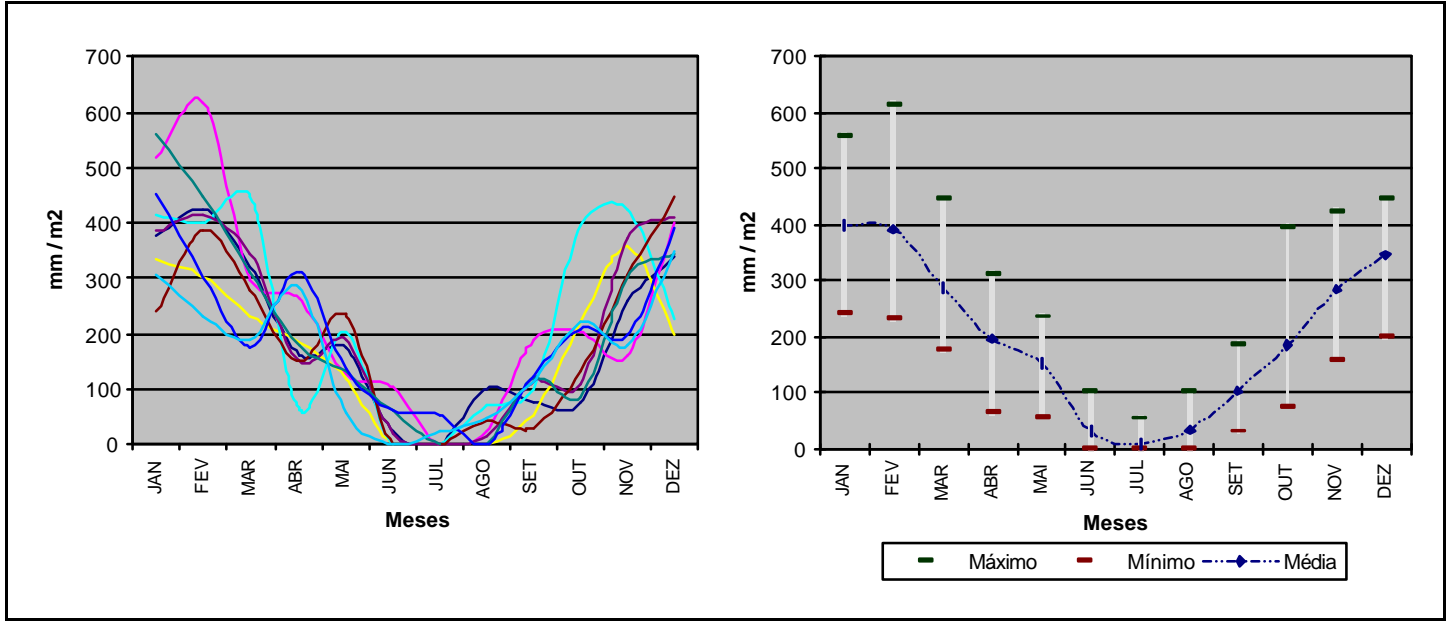

Gráfico 3 - Distribuição sazonal das chuvas: variações e médias mensais.

Fonte: Índices pluviométricos $(2003)^{9}$

Utilizando-se dessas informações, os ganhos de peso conforme as categorias animais definidas através da estratificação por classes de peso (intervalos de 60kg) estão apresentados no Quadro 2. Os resultados assumem que o sistema de produção é extensivo de cria-recria-engorda para a raça nelore e a forragem predominante é a Brachiaria brizantha, de acordo com as características da propriedade definida.

\footnotetext{
${ }^{9}$ Dados primários obtidos na Fazenda Nova Vida, Ariquemes - RO.
} 


\begin{tabular}{|c|c|c|c|c|c|c|c|c|c|c|c|c|c|c|}
\hline \multirow{2}{*}{ Liasses } & \multirow{2}{*}{$\begin{array}{c}\text { Intervaısos ae } \\
\text { Peso }\end{array}$} & \multicolumn{12}{|c|}{ Uıstrıbuıçao ao ganno ae peso ao ıongo ao ano em kg/aıa } & \multirow{2}{*}{$\begin{array}{l}\text { IVlealas } \\
\text { mensais }\end{array}$} \\
\hline & & Jan & tev & mar & abr & mal & jun & JuI & ago & Set & out & nov & aez & \\
\hline Bezerro1 & 30 a $90 \mathrm{Kg}$ & 0,90 & 0,90 & 0,80 & 0,70 & 0,55 & 0,40 & 0,20 & 0,10 & 0,30 & 0,80 & 0,80 & 0,90 & 0,61 \\
\hline Bezerro2 & 90 a $150 \mathrm{Kg}$ & 0,90 & 0,90 & 0,80 & 0,70 & 0,55 & 0,40 & 0,20 & 0,10 & 0,30 & 0,80 & 0,80 & 0,90 & 0,61 \\
\hline Bezerro3 & 150 a $210 \mathrm{Kg}$ & 0,80 & 0,70 & 0,70 & 0,55 & 0,40 & 0,30 & 0,15 & 0,00 & 0,20 & 0,60 & 0,70 & 0,80 & 0,49 \\
\hline Novilho1 & 210 a $270 \mathrm{Kg}$ & 0,70 & 0,70 & 0,70 & 0,50 & 0,40 & 0,25 & 0,15 & 0,00 & 0,20 & 0,50 & 0,60 & 0,70 & 0,45 \\
\hline Novilho2 & 270 a $330 \mathrm{Kg}$ & 0,70 & 0,70 & 0,70 & 0,50 & 0,40 & 0,25 & 0,15 & 0,00 & 0,20 & 0,50 & 0,60 & 0,70 & 0,45 \\
\hline Novilho3 & 330 a $390 \mathrm{Kg}$ & 0,70 & 0,70 & 0,70 & 0,50 & 0,40 & 0,25 & 0,15 & 0,00 & 0,20 & 0,50 & 0,60 & 0,70 & 0,45 \\
\hline Boi1 & 390 a $450 \mathrm{Kg}$ & 0,70 & 0,70 & 0,70 & 0,50 & 0,40 & 0,25 & 0,15 & 0,00 & 0,20 & 0,50 & 0,60 & 0,70 & 0,45 \\
\hline Boi2 & acima $450 \mathrm{Kg}$ & 0,70 & 0,70 & 0,70 & 0,50 & 0,40 & 0,25 & 0,15 & 0,00 & 0,20 & 0,50 & 0,60 & 0,70 & 0,45 \\
\hline Bezerra1 & 30 a $90 \mathrm{Kg}$ & 0,80 & 0,80 & 0,70 & 0,60 & 0,45 & 0,35 & 0,20 & 0,10 & 0,25 & 0,70 & 0,70 & 0,75 & 0,53 \\
\hline Bezerra2 & 90 a $150 \mathrm{Kg}$ & 0,80 & 0,80 & 0,70 & 0,60 & 0,45 & 0,35 & 0,20 & 0,10 & 0,25 & 0,70 & 0,70 & 0,75 & 0,53 \\
\hline Bezerra3 & 150 a $210 \mathrm{Kg}$ & 0,70 & 0,60 & 0,55 & 0,45 & 0,35 & 0,10 & 0,12 & 0,00 & 0,15 & 0,45 & 0,60 & 0,70 & 0,40 \\
\hline Novilha1 & 210 a $270 \mathrm{Kg}$ & 0,70 & 0,60 & 0,55 & 0,45 & 0,35 & 0,10 & 0,12 & 0,00 & 0,15 & 0,45 & 0,60 & 0,70 & 0,40 \\
\hline Novilha2 & 270 a $330 \mathrm{Kg}$ & 0,70 & 0,60 & 0,55 & 0,45 & 0,35 & 0,10 & 0,12 & 0,00 & 0,15 & 0,45 & 0,60 & 0,70 & 0,40 \\
\hline Novilha3 & 330 a $390 \mathrm{Kg}$ & 0,70 & 0,60 & 0,55 & 0,45 & 0,35 & 0,10 & 0,12 & 0,00 & 0,15 & 0,45 & 0,60 & 0,70 & 0,40 \\
\hline Vaca1 & 390 a $400 \mathrm{Kg}$ & 0,70 & 0,60 & 0,55 & 0,45 & 0,35 & 0,10 & 0,12 & 0,00 & $-0,1$ & 0,45 & 0,60 & 0,70 & 0,38 \\
\hline Vaca2 & acima $450 \mathrm{Kg}$ & 0,70 & 0,60 & 0,55 & 0,45 & 0,35 & 0,10 & 0,12 & 0,00 & $-0,1$ & 0,45 & 0,60 & 0,70 & 0,38 \\
\hline
\end{tabular}

Quadro 2 - Ganhos de peso conforme os meses e as categorias de animais.

Fonte: Dados da pesquisa.

Esses valores foram assumidos de forma igual em todos os projetos, dessa forma as diferenças de produtividade ficaram condicionadas penas à capacidade de suporte da pastagem de cada um dos sistemas analisados. Seqüiencialmente, os subitens relativos aos projetos apresentam de forma mais detalhada as práticas agronômicas adotadas nos seis projetos e as respectivas produtividades estimadas para a forragem (expressas na forma das taxas de lotação).

Mudanças no ganho de peso diário dos animais estariam mais associadas a modificações no manejo da suplementação alimentar e em investimentos em genética, mas esses itens não fazem parte do escopo desse trabalho. Em todos os projetos, não foi adotado nenhum tipo de suplementação alimentar a não ser o uso de sal mineral na dosagem de 80 gr. cabeça ${ }^{-1}$ dia $^{-1}$, índice determinado como o mais comum para uso na região. 


\subsection{1 "Projeto 1" (propriedade sem alterações)}

Falhas no planejamento e na condução das propriedades da região amazônica têm provocado a redução significativa do tempo de vida útil das pastagens. Muitas das áreas formadas há mais de duas décadas estão, hoje, em processo de degradação, enquanto que as pastagens constituídas na última década já contam com uma maior conscientização e empenho tecnológico destinados a evitar o desgaste excessivo do solo. A longevidade dos pastos considerados produtivos é muito variável e depende dos fatores administrativos, edáficos e climáticos.

Nesse projeto, assumiu-se a propriedade definida anteriormente, conforme os dados da Tabela 2 e da Tabela 3, sendo que as informações zootécnicas foram mantidas constantes ao longo dos anos. Não foi considerada a execução de nenhuma forma de procedimento visando à recuperação. Por isso, foi incluído o decréscimo linear da capacidade de suporte da pastagem, estimada em $5 \%$ ao ano ${ }^{10}$, haja vista que a propriedade padrão não preza por adotar nenhum tipo de tecnologia para aumentar o tempo de vida da pastagem, como por exemplo: o pastejo rotacionado. A Tabela 5 mostra o decréscimo da razão de unidades animais de $450 \mathrm{~kg}$ (UA) por hectares (ha) e a Tabela 6 mostra a média anual da taxa máxima de lotação, expressa em UA, para toda a propriedade. Esses números foram utilizados como limite máximo nos cálculos da evolução do rebanho.

Tabela 5. Taxas de lotação por ha - Projeto 1.

\begin{tabular}{ccc}
\hline Ano & UA/ha & \% de Redução \\
\hline Ano 0 & 1,05 & - \\
Ano 1 & 1,00 & $-5,00 \%$ \\
Ano 2 & 0,95 & $-5,00 \%$ \\
Ano 3 & 0,90 & $-5,00 \%$ \\
Ano 4 & 0,86 & $-5,00 \%$ \\
Ano 5 & 0,81 & $-5,00 \%$ \\
Ano 6 & 0,77 & $-5,00 \%$ \\
Ano 7 & 0,73 & $-5,00 \%$ \\
\hline
\end{tabular}

Fonte: Dados da pesquisa.

\footnotetext{
${ }^{10}$ A determinação da taxa de $5 \%$ foi estimada em vista das colocações feitas pelos produtores rurais durante os painéis.
} 
Tabela 6. Capacidade de suporte da propriedade - Projeto 1.

\begin{tabular}{ccc}
\hline Anos & $\begin{array}{c}\text { Capacidade em UA/Ha para toda a } \\
\text { propriedade }\end{array}$ & UA/ha \\
\hline Ano 0 & 762 & 1,05 \\
Ano 1 & 724 & 1,00 \\
Ano 2 & 688 & 0,95 \\
Ano 3 & 654 & 0,90 \\
Ano 4 & 621 & 0,86 \\
Ano 5 & 590 & 0,81 \\
Ano 6 & 560 & 0,77 \\
Ano 7 & 532 & 0,73 \\
\hline
\end{tabular}

Fonte: Dados da pesquisa.

\subsection{2 'Projetos 2, 3, 4 e 5’ (sistemas de recuperação de pastagens degradadas)}

Os projetos 2, 3, 4, e 5 correspondem aos mesmos tratamentos realizados no estudo temático Anexo $\mathrm{C}$, por isso as bases técnicas desenvolvidas nas áreas experimentais também foram utilizadas nas análises de viabilidade econômica. Dessa forma, as dosagens de defensivos e fertilizantes empregadas nas áreas experimentais também foram utilizadas nos cálculos dos custos operacionais dos procedimentos a serem usados em cada projeto, e as estimativas de ganho de produtividade foram definidas com base nos resultados preliminares do estudo temático e também com as observações dos técnicos dos órgãos de pesquisa regionais e de algumas empresas produtoras de fertilizantes.

Nos quatro projetos, os objetivos e custos de cada um dos sistemas de recuperação seguiram os parâmetros apresentados no Quadro 3 e no Quadro 4. 


\begin{tabular}{|c|c|c|}
\hline Técnicas de recuperação & Princípios/Objetivos & Práticas agronômicas \\
\hline $\begin{array}{l}\text { Projeto 2- Herbicida + } \\
\text { Adubação } \\
\text { - Controle químico de invasoras } \\
\text { + adubação com N, P, Ke } \\
\text { micronutrientes. } \\
\text { - Semeadura de } \text { B. brizantha. }\end{array}$ & $\begin{array}{l}\text { - Controle de plantas } \\
\text { invasoras com herbicida; } \\
\text { - Aumento de produtividade } \\
\text { pela melhoria da fertilidade } \\
\text { do solo. }\end{array}$ & $\begin{array}{l}\text { - Corte manual das plantas } \\
\text { invasoras. } \\
\text { - Aplicação única do herbicida } \\
\text { 2,4D } \\
\text { - Aplicação de fertilizantes (em } \\
\text { função da análise de solo) em } \\
\text { cobertura. } \\
\text { - Semeadura de B. brizantha. }\end{array}$ \\
\hline $\begin{array}{l}\text { Projeto 3- Gradagem + } \\
\text { Adubação } \\
\text { - Descompactação do solo } \\
\text { (enleiramento + gradagem } \\
\text { aradora + niveladora) } \\
\text { - Semeadura de } \text { B. brizantha, } \\
\text { adubação com N, P, K e } \\
\text { micronutrientes. }\end{array}$ & $\begin{array}{l}\text { - Controle de plantas } \\
\text { invasoras; incorporação de } \\
\text { biomassa vegetal. } \\
\text { - Aumento de produtividade } \\
\text { pela melhoria da fertilidade } \\
\text { do solo. }\end{array}$ & $\begin{array}{l}\text { - Aplicação de fertilizantes (em } \\
\text { função da análise de solo) em } \\
\text { cobertura. } \\
\text { - Gradagem no início da estação } \\
\text { chuvosa; } \\
\text { - Semeadura de B. brizantha. }\end{array}$ \\
\hline $\begin{array}{l}\text { Projeto 4- Sistema Arroz } \\
\text { - Preparo do solo (enleiramento + } \\
\text { gradagem aradora + } \\
\text { niveladora) } \\
\text { - Plantio de arroz + adubação } \\
\text { com N, P, K e micronutrientes. } \\
\text { - Colheita arroz. } \\
\text { - Plantio direto de B. Brizantha }\end{array}$ & $\begin{array}{l}\text { - Recuperação da pastagem } \\
\text { através do preparo do solo e } \\
\text { aproveitamento da adubação } \\
\text { residual fornecida para o } \\
\text { arroz } \\
\text { - Redução dos custos com a } \\
\text { venda dos grãos da cultura } \\
\text { de arroz. }\end{array}$ & $\begin{array}{l}\text { - Preparo do solo } \\
\text { - Semeadura de arroz e } \\
\text { adubação com N, P, K e } \\
\text { micronutrientes recomendada } \\
\text { para o arroz. } \\
\text { - Colheita arroz } \\
\text { - Plantio direto de B. Brizantha. }\end{array}$ \\
\hline $\begin{array}{l}\text { Projeto 5- Sistema Soja } \\
\text { - Preparo do solo (enleiramento + } \\
\text { gradagem aradora + } \\
\text { niveladora) } \\
\text { - Plantio convencional de soja } \\
\text { tardia (inoculada com } \\
\text { Rhizobium) + adubação com } \\
\text { P, K e micronutrientes. } \\
\text { - Colheita soja. } \\
\text { - Plantio direto de B. brizantha. }\end{array}$ & $\begin{array}{l}\text { - Recuperação da pastagem } \\
\text { através do preparo do solo e } \\
\text { aproveitamento da adubação } \\
\text { residual fornecida para a } \\
\text { soja } \\
\text { - Adição de nitrogênio ao solo } \\
\text { através da fixação biológica } \\
\text { - Redução dos custos da } \\
\text { reabilitação com a venda de } \\
\text { grãos de soja. }\end{array}$ & $\begin{array}{l}\text { - Preparo do solo } \\
\text { - Plantio convencional de soja } \\
\text { tardia (inoculada com } \\
\text { Rhizobium) + adubação com P, } \\
\text { K e micronutrientes. } \\
\text { - Colheita soja } \\
\text { - Plantio direto de B. Brizantha. }\end{array}$ \\
\hline
\end{tabular}

Quadro 3 - Descrição dos sistemas de recuperação de pastagens a serem estudados. Fonte: CENA (2003) ${ }^{11}$

\footnotetext{
${ }^{11}$ Projeto temático: avaliação de sistemas de recuperação de pastagens degradadas na Amazônia em elaboração.
} 


\begin{tabular}{|c|c|}
\hline Projetos & Aplicações \\
\hline $\begin{array}{l}\text { Projeto } 2 \\
\text { Herbicida }\end{array}$ & $\begin{array}{l}\text { aplicação de herbicida seletivo 2,4 D } \\
\text { fertilização com } 42 \mathrm{~kg} \mathrm{~N} \mathrm{ha}^{-1}, 27 \mathrm{~kg} \mathrm{~K} \mathrm{ha}^{-1} \mathrm{e} 48 \mathrm{kgP} \mathrm{ha}^{-1} \text {; }\end{array}$ \\
\hline $\begin{array}{l}\text { Projeto } 3 \\
\text { Gradagem }\end{array}$ & $\begin{array}{l}\text { replantio da Brachiaria brizantha } \\
\text { fertilização de base com } 76 \mathrm{~kg} \mathrm{P} \mathrm{ha}^{-1} \\
\text { cobertura com } 42 \mathrm{~kg} \mathrm{~N} \mathrm{ha}^{-1}, 27 \mathrm{~kg} \mathrm{~K} \mathrm{ha}^{-1}, 204 \mathrm{~kg} \mathrm{Ca} \mathrm{ha}^{-1}, 72 \mathrm{~kg} \mathrm{Mg} \mathrm{ha}^{-1}, 89 \\
\mathrm{~kg} \mathrm{~S} \mathrm{ha}^{-1} \text { e } 30 \mathrm{~kg} \text { micronutrientes ha }\end{array}$ \\
\hline $\begin{array}{l}\text { Projeto } 4 \\
\text { Arroz }\end{array}$ & $\begin{array}{l}\text { aplicação seqüencial de Glifosato } \\
\text { aplicação de herbicida seletivo 2,4 D } \\
\text { aplicação de herbicida Paraquat } \\
\text { aplicação de inseticidas Finopril e Dodecacloro } \\
\text { plantio de arroz - variedade "primavera" } \\
\text { fertilizado com } 39 \mathrm{~kg} \mathrm{P} \mathrm{ha}^{-1} \text { de base } \\
\text { cobertura com } 33 \mathrm{~kg} \mathrm{~N} \mathrm{ha}^{-1}, 61 \mathrm{~kg} \mathrm{~K} \mathrm{ha}^{-1}, 106 \mathrm{~kg} \mathrm{Ca} \mathrm{ha}^{-1}, 37 \mathrm{~kg} \mathrm{Mg} \mathrm{ha}^{-1}, 60 \\
\mathrm{~kg} \mathrm{~S} \mathrm{ha}^{-1} \text { e } 30 \mathrm{~kg} \text { micronutrientes ha }^{-1}\end{array}$ \\
\hline $\begin{array}{l}\text { Projeto } 5 \\
\text { Soja }\end{array}$ & $\begin{array}{l}\text { aplicação seqüencial Glifosato } \\
\text { aplicação de herbicida seletivo 2,4 D } \\
\text { aplicação de herbicida Paraquat } \\
\text { aplicação de herbicida Betazon } \\
\text { aplicação de inseticidas Finopril e Dodecacloı } \\
\text { aplicação de inseticidas Endosulfan e Clorpirifós } \\
\text { plantio da soja - variedade "conquista" } \\
\text { fertilizado com } 39 \mathrm{~kg} \mathrm{P} \mathrm{ha}^{-1} \\
\text { cobertura com } 71 \mathrm{~kg} \mathrm{~K} \mathrm{ha}^{-1}, 106 \mathrm{~kg} \mathrm{Ca} \mathrm{ha}^{-1}, 37 \mathrm{~kg} \mathrm{Mg} \mathrm{ha}^{-1}, 22{\mathrm{~kg} \mathrm{~S} h{ }^{-1} \text { e } 30}_{\mathrm{kg} \text { micronutrientes ha'. }}\end{array}$ \\
\hline
\end{tabular}

Quadro 4 - Especificacão da aplicação de defensivos, sementes e fertilizantes. Fonte: CENA (2003) ${ }^{12}$

A quantidade do rebanho suportada após o tratamento das pastagens foi estimada para cada tratamento, conforme a eficiência residual da aplicação dos fertilizantes. Os cálculos da taxa de lotação, nos anos subseqüentes à realização das operações, derivaram dos dados empíricos relatados por agentes de revenda de fertilizantes, pesquisadores e de produtores rurais, não apenas da região de Rondônia, mas também de outras regiões onde foram elaborados os painéis (MS, GO, PA, MT) que pudessem se assemelhar à condições definidas para a propriedade padrão.

\footnotetext{
12 Projeto temático: avaliação de sistemas de recuperação de pastagens degradadas na Amazônia em elaboração.
} 
Os resultados das estimativas da taxa de lotação para o projeto 2 - recuperação através do uso de herbicidas e adubação - estão apresentados na Tabela 7 e no Quadro 5. Os valores apresentados no Quadro 5 correspondem, em unidades animais, a capacidade suportada ao longo dos anos. Para efeito dos cálculos foi adotado que os ganhos decorrentes desse tipo de recuperação ocorram até o quarto ano, a partir cessa data as perdas seguem o ritmo constante de 5\% a.a., conforme as perdas assumidas para o projeto 1 (sem alteração). Além disso, entre o ano 0 e o ano 1, foi considerado que o processo de aplicação de herbicidas e vedação do pasto tenha durado 3 meses. Nesse período a respectiva área em tratamento não foi considerada, sendo subtraída no cálculo da taxa média anual de lotação no ano 0 .

Tabela 7. Taxa de lotação por ha - Projeto 2. Herbicida e adubação.

\begin{tabular}{ccc}
\hline Ano & UA/ha & \% de Redução \\
\hline Ano 0 & 0,88 & - \\
Ano 1 & 1,83 & - \\
Ano 2 & 1,50 & $-25,00 \%$ \\
Ano 3 & 1,25 & $-17,00 \%$ \\
Ano 4 & 1,11 & $-11,00 \%$ \\
Ano 5 & 1,05 & $-5,00 \%$ \\
Ano 6 & 1,00 & $-5,00 \%$ \\
Ano 7 & 0,95 & $-5,00 \%$ \\
\hline
\end{tabular}

Fonte: Dados da pesquisa.

Na Tabela 7 o ano 0 corresponde ao ano em que será adotada a prática de recuperação. Lembrando que a taxa de lotação média é de 1,05 UA/ha, a taxa do ano 0 se torna inferior, pois a área de pastagem que está sendo recuperada é vedada e não pode ser considerada, em decorrência desse fator a média em UA/ha do ano 0 é inferior aquela observada no mesmo ano na Tabela 5 (no projeto 1 - sem alteração - onde a média do ano zero permanece em 1,05 ua/ha). Ou seja, nesse projeto (projeto 2) o pasto fica vedado durante 3 meses (novembro do ano 0 a janeiro do ano 1), por isso a taxa média anual de 1,05 sofre desconto em dois meses ficando em 0,875 .

No ano seguinte a taxa aumenta, mas também leva em consideração o tempo em que o pasto ainda está vedado. Nesse exemplo, a taxa de lotação após a recuperação gira em torno de 2,0 UA/Ha, mas como o pasto ficará inutilizado no mês de janeiro a taxa cai 
para 1,83 UA/Ha. Nos anos seguintes a taxa decresce de forma acentuada e depois de forma linear acompanhando a queda de $5 \%$ ao ano.

\begin{tabular}{|c|c|c|c|c|c|c|c|c|c|c|c|}
\hline & $\begin{array}{c}\text { Área não } \\
\text { recuperada } \\
(20 \%)\end{array}$ & $\begin{array}{c}\text { Área } \\
\text { recuperada } \\
\text { no ano } 0\end{array}$ & $\begin{array}{c}\text { Área } \\
\text { recuperada } \\
\text { no ano } 1\end{array}$ & $\begin{array}{c}\text { Área } \\
\text { recuperada } \\
\text { no ano } 2\end{array}$ & $\begin{array}{c}\text { Área } \\
\text { recuperada } \\
\text { no ano } 3\end{array}$ & $\begin{array}{c}\text { Área } \\
\text { recuperada } \\
\text { no ano } 4\end{array}$ & $\begin{array}{c}\text { Área } \\
\text { recuperada } \\
\text { no ano } 5\end{array}$ & $\begin{array}{c}\text { Área } \\
\text { recuperada } \\
\text { no ano } 6\end{array}$ & $\begin{array}{c}\text { Área } \\
\text { recuperada } \\
\text { no ano } 7\end{array}$ & \multicolumn{2}{|c|}{ Área total de pastagem } \\
\hline Hectares & $142 \mathrm{Ha}$ & $73 \mathrm{Ha}$ & $73 \mathrm{Ha}$ & $73 \mathrm{Ha}$ & $73 \mathrm{Ha}$ & $73 \mathrm{Ha}$ & $73 \mathrm{Ha}$ & $73 \mathrm{Ha}$ & $73 \mathrm{Ha}$ & \multicolumn{2}{|c|}{$726 \mathrm{Ha}$} \\
\hline Anos & $\begin{array}{c}\text { Suporte da } \\
\text { área não } \\
\text { recuperada } \\
(20 \%)\end{array}$ & $\begin{array}{l}\text { Suporte da } \\
\text { área } \\
\text { recuperada } \\
\text { no ano } 0\end{array}$ & $\begin{array}{l}\text { Suporte da } \\
\text { área } \\
\text { recuperada } \\
\text { no ano } 1\end{array}$ & $\begin{array}{l}\text { Suporte da } \\
\text { área } \\
\text { recuperada } \\
\text { no ano } 2\end{array}$ & $\begin{array}{c}\text { Suporte da } \\
\text { área } \\
\text { recuperada } \\
\text { no ano } 3\end{array}$ & $\begin{array}{l}\text { Suporte da } \\
\text { área } \\
\text { recuperada } \\
\text { no ano } 4\end{array}$ & $\begin{array}{l}\text { Suporte da } \\
\text { área } \\
\text { recuperada } \\
\text { no ano } 5\end{array}$ & $\begin{array}{l}\text { Suporte da } \\
\text { área } \\
\text { recuperada } \\
\text { no ano } 6\end{array}$ & $\begin{array}{l}\text { Suporte da } \\
\text { área } \\
\text { recuperada } \\
\text { no ano } 7\end{array}$ & $\begin{array}{l}\text { Suporte da } \\
\text { área total da } \\
\text { propriedade }\end{array}$ & $\begin{array}{c}\text { Média em } \\
\text { Ua/ha }\end{array}$ \\
\hline Ano 0 & $149 \mathrm{Ua}$ & $64 \mathrm{Ua}$ & $77 \mathrm{Ua}$ & $77 \mathrm{Ua}$ & $77 \mathrm{Ua}$ & $77 \mathrm{Ua}$ & $77 \mathrm{Ua}$ & $77 \mathrm{Ua}$ & $77 \mathrm{Ua}$ & $750 \mathrm{Ua}$ & 1,032 \\
\hline Ano 1 & $142 \mathrm{Ua}$ & $134 \mathrm{Ua}$ & $61 \mathrm{Ua}$ & $73 \mathrm{Ua}$ & $73 \mathrm{Ua}$ & $73 \mathrm{Ua}$ & $73 \mathrm{Ua}$ & $73 \mathrm{Ua}$ & $73 \mathrm{Ua}$ & $773 \mathrm{Ua}$ & 1,065 \\
\hline Ano 2 & $135 \mathrm{Ua}$ & $110 \mathrm{Ua}$ & $134 \mathrm{Ua}$ & $58 \mathrm{Ua}$ & $69 \mathrm{Ua}$ & $69 \mathrm{Ua}$ & $69 \mathrm{Ua}$ & $69 \mathrm{Ua}$ & $69 \mathrm{Ua}$ & $781 \mathrm{Ua}$ & 1,076 \\
\hline Ano 3 & $128 \mathrm{Ua}$ & $91 \mathrm{Ua}$ & $110 \mathrm{Ua}$ & $134 \mathrm{Ua}$ & $55 \mathrm{Ua}$ & $66 \mathrm{Ua}$ & $66 \mathrm{Ua}$ & $66 \mathrm{Ua}$ & $66 \mathrm{Ua}$ & $780 \mathrm{Ua}$ & 1,074 \\
\hline Ano 4 & $121 \mathrm{Ua}$ & $81 \mathrm{Ua}$ & $91 \mathrm{Ua}$ & $110 \mathrm{Ua}$ & $134 \mathrm{Ua}$ & $52 \mathrm{Ua}$ & $62 \mathrm{Ua}$ & $62 \mathrm{Ua}$ & $62 \mathrm{Ua}$ & $776 \mathrm{Ua}$ & 1,069 \\
\hline Ano 5 & $115 \mathrm{Ua}$ & $77 \mathrm{Ua}$ & $81 \mathrm{Ua}$ & $91 \mathrm{Ua}$ & $110 \mathrm{Ua}$ & $134 \mathrm{Ua}$ & $49 \mathrm{Ua}$ & $59 \mathrm{Ua}$ & $59 \mathrm{Ua}$ & $775 \mathrm{Ua}$ & 1,068 \\
\hline Ano 6 & $110 \mathrm{Ua}$ & $73 \mathrm{Ua}$ & $77 \mathrm{Ua}$ & $81 \mathrm{Ua}$ & $91 \mathrm{Ua}$ & $110 \mathrm{Ua}$ & $134 \mathrm{Ua}$ & $47 \mathrm{Ua}$ & $56 \mathrm{Ua}$ & $778 \mathrm{Ua}$ & 1,071 \\
\hline Ano 7 & $104 \mathrm{Ua}$ & $69 \mathrm{Ua}$ & $73 \mathrm{Ua}$ & $77 \mathrm{Ua}$ & $81 \mathrm{Ua}$ & $91 \mathrm{Ua}$ & $110 \mathrm{Ua}$ & $134 \mathrm{Ua}$ & $45 \mathrm{Ua}$ & $783 \mathrm{Ua}$ & 1,079 \\
\hline
\end{tabular}

Quadro 5 - Capacidade de suporte da propriedade - Projeto 2. Herbicida e adubação.

Fonte: Dados da pesquisa.

A coluna "Cap.Total" (capacidade total de suporte da pastagem), no Quadro 5, determina quantas unidades animais podem ser colocadas na propriedade ao longo dos anos. Para isso o cálculo é conduzido da seguinte forma:

i) a propriedade de 726 ha foi dividida em oito piquetes de 73 hectares $(10 \%$ da área) e um piquete maior (142 ha ou 20\% da área) onde as técnicas de recuperação não serão empregadas.

ii) a cada ano um pique te de 73 ha será recuperado, por isso a coluna "Área recuperada ano 0" indica a quantidade de UA que o piquete que foi recuperado irá suportar no ano 0 e nos anos conseguintes. As estimativas levam em consideração a Tabela 7 e a área de 73 ha.

iii) o segundo piquete (coluna “Área recuperada ano 1") será recuperado no ano 1, o terceiro no ano 2 e assim sucessivamente todos os piquetes passarão pelo procedimento em oito anos (ano 0 até o ano 7). Entretanto, até que a pastagem dos piquetes sejam recuperadas ocorrerá a redução de 5\% ao ano (mesmo valor que aquele empregado no projeto 1- sem alterações).

Tendo por exemplo o piquete que será recuperado no ano 5 (coluna “Área recuperada ano 5"). Até o ano 4 é possível notar que há uma redução de 5\% na taxa de 
lotação da pastagem (iniciada em 77 UA/ha e reduzida para 62 UA/ha no ano 4). No ano 5 seria esperado o valor de $59 \mathrm{UA} / \mathrm{ha}$, mas a queda é maior, pois foi considerada a vedação, dada a operação da recuperação da pastagem, que incidiu sobre esse piquete no quinto ano. A partir do sexto ano o piquete aumenta capacidade, mas nos anos seguintes novamente as taxas voltam a cair na mesma proporção que a tabela anterior.

Para todos os outros projetos a mesma linha de raciocínio foi seguida, por isso as duas tabelas são encontradas na descrição de todos os projetos avaliados neste estudo.

Portanto, seguindo o mesmo raciocínio do projeto 2, os resultados das estimativas da taxa de lotação para o projeto 3 - recuperação através do uso de gradagem e adubação - estão apresentados na Tabela 8 e no Quadro 6. Para efeito dos cálculos foi adotado que os ganhos decorrentes desse procedimento ocorram até o quinto ano, depois seguem o ritmo constante de perda de $5 \%$ a.a. Entre o ano 0 e o ano 1, foi considerado que o processo de gradagem, adubação, semeio e crescimento da forragem tenha durado 4 meses. Nesse período a respectiva área não foi considerada como área de pasto, sendo subtraída no cálculo da taxa média anual de lotação nos anos 0 e 1.

Tabela 8. Taxa de lotação por ha - Projeto 3. Gradagem e adubação.

\begin{tabular}{ccc}
\hline Ano & UA/ha & \% de Redução \\
\hline Ano 0 & 0,79 & - \\
Ano 1 & 2,75 & - \\
Ano 2 & 2,10 & $-30,00 \%$ \\
Ano 3 & 1,58 & $-25,00 \%$ \\
Ano 4 & 1,28 & $-19,00 \%$ \\
Ano 5 & 1,11 & $-13,00 \%$ \\
Ano 6 & 1,05 & $-5,00 \%$ \\
Ano 7 & 1,00 & $-5,00 \%$ \\
\hline
\end{tabular}

Fonte: Dados da pesquisa. 


\begin{tabular}{|c|c|c|c|c|c|c|c|c|c|c|c|}
\hline & $\begin{array}{c}\text { Área não } \\
\text { recuperada } \\
(20 \%)\end{array}$ & $\begin{array}{c}\text { Área } \\
\text { recuperada } \\
\text { no ano } 0\end{array}$ & $\begin{array}{c}\text { Área } \\
\text { recuperada } \\
\text { no ano } 1\end{array}$ & $\begin{array}{c}\text { Área } \\
\text { recuperada } \\
\text { no ano } 2\end{array}$ & $\begin{array}{c}\text { Área } \\
\text { recuperada } \\
\text { no ano } 3\end{array}$ & $\begin{array}{c}\text { Área } \\
\text { recuperada } \\
\text { no ano } 4\end{array}$ & $\begin{array}{c}\text { Área } \\
\text { recuperada } \\
\text { no ano } 5\end{array}$ & $\begin{array}{c}\text { Área } \\
\text { recuperada } \\
\text { no ano } 6\end{array}$ & $\begin{array}{c}\text { Área } \\
\text { recuperada } \\
\text { no ano } 7\end{array}$ & \multicolumn{2}{|c|}{ Área total de pastagem } \\
\hline Hectares & $142 \mathrm{Ha}$ & $73 \mathrm{Ha}$ & $73 \mathrm{Ha}$ & $73 \mathrm{Ha}$ & $73 \mathrm{Ha}$ & $73 \mathrm{Ha}$ & $73 \mathrm{Ha}$ & $73 \mathrm{Ha}$ & $73 \mathrm{Ha}$ & \multicolumn{2}{|c|}{$726 \mathrm{Ha}$} \\
\hline Anos & $\begin{array}{c}\text { Suporte da } \\
\text { área não } \\
\text { recuperada } \\
(20 \%)\end{array}$ & $\begin{array}{l}\text { Suporte da } \\
\text { área } \\
\text { recuperada } \\
\text { no ano } 0\end{array}$ & $\begin{array}{l}\text { Suporte da } \\
\text { área } \\
\text { recuperada } \\
\text { no ano } 1\end{array}$ & $\begin{array}{l}\text { Suporte da } \\
\text { área } \\
\text { recuperada } \\
\text { no ano } 2\end{array}$ & $\begin{array}{l}\text { Suporte da } \\
\text { área } \\
\text { recuperada } \\
\text { no ano } 3\end{array}$ & $\begin{array}{l}\text { Suporte da } \\
\text { área } \\
\text { recuperada } \\
\text { no ano } 4\end{array}$ & $\begin{array}{l}\text { Suporte da } \\
\text { área } \\
\text { recuperada } \\
\text { no ano } 5\end{array}$ & $\begin{array}{l}\text { Suporte da } \\
\text { área } \\
\text { recuperada } \\
\text { no ano } 6\end{array}$ & $\begin{array}{l}\text { Suporte da } \\
\text { área } \\
\text { recuperada } \\
\text { no ano } 7\end{array}$ & $\begin{array}{l}\text { Suporte da } \\
\text { área total da } \\
\text { propriedade }\end{array}$ & $\begin{array}{c}\text { Média em } \\
\text { Ua/ha }\end{array}$ \\
\hline Ano 0 & $149 \mathrm{Ua}$ & $57 \mathrm{Ua}$ & $77 \mathrm{Ua}$ & $77 \mathrm{Ua}$ & $77 \mathrm{Ua}$ & $77 \mathrm{Ua}$ & $77 \mathrm{Ua}$ & $77 \mathrm{Ua}$ & $77 \mathrm{Ua}$ & $743 \mathrm{Ua}$ & 1,024 \\
\hline Ano 1 & $142 \mathrm{Ua}$ & $201 \mathrm{Ua}$ & $55 \mathrm{Ua}$ & $73 \mathrm{Ua}$ & $73 \mathrm{Ua}$ & $73 \mathrm{Ua}$ & $73 \mathrm{Ua}$ & $73 \mathrm{Ua}$ & $73 \mathrm{Ua}$ & $834 \mathrm{Ua}$ & 1,149 \\
\hline Ano 2 & $135 \mathrm{Ua}$ & $153 \mathrm{Ua}$ & $201 \mathrm{Ua}$ & $52 \mathrm{Ua}$ & $69 \mathrm{Ua}$ & $69 \mathrm{Ua}$ & $69 \mathrm{Ua}$ & $69 \mathrm{Ua}$ & $69 \mathrm{Ua}$ & $886 \mathrm{Ua}$ & 1,221 \\
\hline Ano 3 & $128 \mathrm{Ua}$ & $115 \mathrm{Ua}$ & $153 \mathrm{Ua}$ & $201 \mathrm{Ua}$ & $49 \mathrm{Ua}$ & $66 \mathrm{Ua}$ & $66 \mathrm{Ua}$ & $66 \mathrm{Ua}$ & $66 \mathrm{Ua}$ & $909 \mathrm{Ua}$ & 1,252 \\
\hline Ano 4 & $121 \mathrm{Ua}$ & $93 \mathrm{Ua}$ & $115 \mathrm{Ua}$ & $153 \mathrm{Ua}$ & $201 \mathrm{Ua}$ & $47 \mathrm{Ua}$ & $62 \mathrm{Ua}$ & $62 \mathrm{Ua}$ & $62 \mathrm{Ua}$ & $918 \mathrm{Ua}$ & 1,264 \\
\hline Ano 5 & $115 \mathrm{Ua}$ & $81 \mathrm{Ua}$ & $93 \mathrm{Ua}$ & $115 \mathrm{Ua}$ & $153 \mathrm{Ua}$ & $201 \mathrm{Ua}$ & $44 \mathrm{Ua}$ & $59 \mathrm{Ua}$ & $59 \mathrm{Ua}$ & $922 \mathrm{Ua}$ & 1,269 \\
\hline Ano 6 & $110 \mathrm{Ua}$ & $77 \mathrm{Ua}$ & $81 \mathrm{Ua}$ & $93 \mathrm{Ua}$ & $115 \mathrm{Ua}$ & $153 \mathrm{Ua}$ & $201 \mathrm{Ua}$ & $42 \mathrm{Ua}$ & $56 \mathrm{Ua}$ & $928 \mathrm{Ua}$ & 1,279 \\
\hline Ano 7 & $104 \mathrm{Ua}$ & $73 \mathrm{Ua}$ & $77 \mathrm{Ua}$ & $81 \mathrm{Ua}$ & $93 \mathrm{Ua}$ & $115 \mathrm{Ua}$ & $153 \mathrm{Ua}$ & $201 \mathrm{Ua}$ & $40 \mathrm{Ua}$ & $938 \mathrm{Ua}$ & 1,291 \\
\hline
\end{tabular}

Quadro 6 - Capacidade de suporte da propriedade - Projeto 3. Gradagem e adubação. Fonte: Dados da pesquisa.

As estimativas da taxa de lotação para o projeto 4 - recuperação através dos ganhos residuais da cultura de arroz - estão apresentados na Tabela 9 e no Quadro 7. Para efeito dos cálculos foi adotado que os ganhos residuais da adubação utilizada no cultivo agrícola ocorram até o quarto ano, depois seguem o ritmo constante de perda de $5 \%$ a.a. Entre o ano 0 e o ano 1, foi considerado que o todo o processo do cultivo do arroz e posterior crescimento da forragem tenha durado de 6 a 7 meses. Portanto, a respectiva área em uso agrícola não foi considerada no cálculo da taxa média anual de lotação nos últimos meses do ano 0 e nos primeiros do ano 1 .

Tabela 9. Taxa de lotação por ha - Projeto 4. Cultivo do arroz.

\begin{tabular}{ccc}
\hline Ano & UA/ha & \% de Redução \\
\hline Ano 0 & 0,79 & - \\
Ano 1 & 1,27 & - \\
Ano 2 & 1,52 & $-20,00 \%$ \\
Ano 3 & 1,29 & $-15,00 \%$ \\
Ano 4 & 1,14 & $-12,00 \%$ \\
Ano 5 & 1,08 & $-5,00 \%$ \\
Ano 6 & 1,03 & $-5,00 \%$ \\
Ano 7 & 0,97 & $-5,00 \%$ \\
\hline
\end{tabular}

Fonte: Dados da pesquisa. 


\begin{tabular}{|c|c|c|c|c|c|c|c|c|c|c|c|}
\hline & $\begin{array}{c}\text { Área não } \\
\text { recuperada } \\
(20 \%)\end{array}$ & $\begin{array}{c}\text { Área } \\
\text { recuperada } \\
\text { no ano } 0\end{array}$ & $\begin{array}{c}\text { Área } \\
\text { recuperada } \\
\text { no ano } 1\end{array}$ & $\begin{array}{c}\text { Área } \\
\text { recuperada } \\
\text { no ano } 2\end{array}$ & $\begin{array}{c}\text { Área } \\
\text { recuperada } \\
\text { no ano } 3\end{array}$ & $\begin{array}{c}\text { Área } \\
\text { recuperada } \\
\text { no ano } 4\end{array}$ & $\begin{array}{c}\text { Área } \\
\text { recuperada } \\
\text { no ano } 5\end{array}$ & $\begin{array}{c}\text { Área } \\
\text { recuperada } \\
\text { no ano } 6\end{array}$ & $\begin{array}{c}\text { Área } \\
\text { recuperada } \\
\text { no ano } 7\end{array}$ & \multicolumn{2}{|c|}{ Área total de pastagem } \\
\hline Hectares & $142 \mathrm{Ha}$ & $73 \mathrm{Ha}$ & $73 \mathrm{Ha}$ & $73 \mathrm{Ha}$ & $73 \mathrm{Ha}$ & $73 \mathrm{Ha}$ & $73 \mathrm{Ha}$ & $73 \mathrm{Ha}$ & $73 \mathrm{Ha}$ & \multicolumn{2}{|c|}{$726 \mathrm{Ha}$} \\
\hline Anos & $\begin{array}{l}\text { Suporte da } \\
\text { área não } \\
\text { recuperada } \\
(20 \%)\end{array}$ & $\begin{array}{l}\text { Suporte da } \\
\text { área } \\
\text { recuperada } \\
\text { no ano } 0\end{array}$ & $\begin{array}{l}\text { Suporte da } \\
\text { área } \\
\text { recuperada } \\
\text { no ano } 1\end{array}$ & $\begin{array}{l}\text { Suporte da } \\
\text { área } \\
\text { recuperada } \\
\text { no ano } 2\end{array}$ & $\begin{array}{c}\text { Suporte da } \\
\text { área } \\
\text { recuperada } \\
\text { no ano } 3\end{array}$ & $\begin{array}{l}\text { Suporte da } \\
\text { área } \\
\text { recuperada } \\
\text { no ano } 4\end{array}$ & $\begin{array}{l}\text { Suporte da } \\
\text { área } \\
\text { recuperada } \\
\text { no ano } 5\end{array}$ & $\begin{array}{l}\text { Suporte da } \\
\text { área } \\
\text { recuperada } \\
\text { no ano } 6\end{array}$ & $\begin{array}{l}\text { Suporte da } \\
\text { área } \\
\text { recuperada } \\
\text { no ano } 7\end{array}$ & $\begin{array}{l}\text { Suporte da } \\
\text { área total da } \\
\text { propriedade }\end{array}$ & $\begin{array}{c}\text { Média em } \\
\text { Ua/ha }\end{array}$ \\
\hline Ano 0 & $149 \mathrm{Ua}$ & $57 \mathrm{Ua}$ & $77 \mathrm{Ua}$ & $77 \mathrm{Ua}$ & $77 \mathrm{Ua}$ & $77 \mathrm{Ua}$ & $77 \mathrm{Ua}$ & $77 \mathrm{Ua}$ & $77 \mathrm{Ua}$ & $743 \mathrm{Ua}$ & 1,024 \\
\hline Ano 1 & $142 \mathrm{Ua}$ & $92 \mathrm{Ua}$ & $55 \mathrm{Ua}$ & $73 \mathrm{Ua}$ & $73 \mathrm{Ua}$ & $73 \mathrm{Ua}$ & $73 \mathrm{Ua}$ & $73 \mathrm{Ua}$ & $73 \mathrm{Ua}$ & $726 \mathrm{Ua}$ & 0,999 \\
\hline Ano 2 & $135 \mathrm{Ua}$ & $111 \mathrm{Ua}$ & $92 \mathrm{Ua}$ & $52 \mathrm{Ua}$ & $69 \mathrm{Ua}$ & $69 \mathrm{Ua}$ & $69 \mathrm{Ua}$ & $69 \mathrm{Ua}$ & $69 \mathrm{Ua}$ & $736 \mathrm{Ua}$ & 1,013 \\
\hline Ano 3 & $128 \mathrm{Ua}$ & $94 \mathrm{Ua}$ & $111 \mathrm{Ua}$ & $92 \mathrm{Ua}$ & $49 \mathrm{Ua}$ & $66 \mathrm{Ua}$ & $66 \mathrm{Ua}$ & $66 \mathrm{Ua}$ & $66 \mathrm{Ua}$ & $738 \mathrm{Ua}$ & 1,016 \\
\hline Ano 4 & $121 \mathrm{Ua}$ & $83 \mathrm{Ua}$ & $94 \mathrm{Ua}$ & $111 \mathrm{Ua}$ & $92 \mathrm{Ua}$ & $47 \mathrm{Ua}$ & $62 \mathrm{Ua}$ & $62 \mathrm{Ua}$ & $62 \mathrm{Ua}$ & $736 \mathrm{Ua}$ & 1,014 \\
\hline Ano 5 & $115 \mathrm{Ua}$ & $79 \mathrm{Ua}$ & $83 \mathrm{Ua}$ & $94 \mathrm{Ua}$ & $111 \mathrm{Ua}$ & $92 \mathrm{Ua}$ & $44 \mathrm{Ua}$ & $59 \mathrm{Ua}$ & $59 \mathrm{Ua}$ & $738 \mathrm{Ua}$ & 1,017 \\
\hline Ano 6 & $110 \mathrm{Ua}$ & $75 \mathrm{Ua}$ & $79 \mathrm{Ua}$ & $83 \mathrm{Ua}$ & $94 \mathrm{Ua}$ & $111 \mathrm{Ua}$ & $92 \mathrm{Ua}$ & $42 \mathrm{Ua}$ & $56 \mathrm{Ua}$ & $743 \mathrm{Ua}$ & 1,023 \\
\hline Ano 7 & $104 \mathrm{Ua}$ & $71 \mathrm{Ua}$ & $75 \mathrm{Ua}$ & $79 \mathrm{Ua}$ & $83 \mathrm{Ua}$ & $94 \mathrm{Ua}$ & $111 \mathrm{Ua}$ & $92 \mathrm{Ua}$ & $40 \mathrm{Ua}$ & $750 \mathrm{Ua}$ & 1,033 \\
\hline
\end{tabular}

Quadro 7 - Capacidade de suporte da propriedade - Projeto 4. Cultivo do arroz. Fonte: Dados da pesquisa.

As estimativas da taxa de lotação para o projeto 5 - recuperação através dos ganhos residuais da cultura de soja - estão apresentados na Tabela 10 e no Quadro 8. Para efeito dos cálculos foi adotado que os ganhos residuais da adubação utilizada no cultivo agrícola e da fixação do nitrogênio natural ocorram até o quarto ano, depois seguem o ritmo constante de perda de $5 \%$ a.a. Entre o ano 0 e o ano 1, foi considerado que o uso do solo para o cultivo da soja e posterior plantio e crescimento da forragem tenha durado de 7 a 8 meses, período em que a área em uso agrícola não foi considerada no cálculo da taxa média anual de lotação nos meses correspondentes do ano 0 e 1 .

Tabela 10. Taxa de lotação por ha - Projeto 5. Cultivo da soja.

\begin{tabular}{ccc}
\hline Ano & UA/ha & \% de Redução \\
\hline Ano 0 & 0,79 & - \\
Ano 1 & 1,46 & - \\
Ano 2 & 1,85 & $-26,00 \%$ \\
Ano 3 & 1,44 & $-22,00 \%$ \\
Ano 4 & 1,20 & $-17,00 \%$ \\
Ano 5 & 1,10 & $-8,00 \%$ \\
Ano 6 & 1,05 & $-5,00 \%$ \\
Ano 7 & 0,99 & $-5,00 \%$ \\
\hline
\end{tabular}

Fonte: Dados da pesquisa. 


\begin{tabular}{|c|c|c|c|c|c|c|c|c|c|c|c|}
\hline & $\begin{array}{c}\text { Área não } \\
\text { recuperada } \\
(20 \%)\end{array}$ & $\begin{array}{c}\text { Área } \\
\text { recuperada } \\
\text { no ano } 0\end{array}$ & $\begin{array}{c}\text { Área } \\
\text { recuperada } \\
\text { no ano } 1\end{array}$ & $\begin{array}{c}\text { Área } \\
\text { recuperada } \\
\text { no ano } 2\end{array}$ & $\begin{array}{c}\text { Área } \\
\text { recuperada } \\
\text { no ano } 3\end{array}$ & $\begin{array}{c}\text { Área } \\
\text { recuperada } \\
\text { no ano } 4\end{array}$ & $\begin{array}{c}\text { Área } \\
\text { recuperada } \\
\text { no ano } 5\end{array}$ & $\begin{array}{c}\text { Área } \\
\text { recuperada } \\
\text { no ano } 6\end{array}$ & $\begin{array}{c}\text { Área } \\
\text { recuperada } \\
\text { no ano } 7\end{array}$ & \multicolumn{2}{|c|}{ Área total de pastagem } \\
\hline \multicolumn{12}{|l|}{ Hectares } \\
\hline Anos & $\begin{array}{c}\text { Suporte da } \\
\text { área não } \\
\text { recuperada } \\
(20 \%)\end{array}$ & $\begin{array}{l}\text { Suporte da } \\
\text { área } \\
\text { recuperada } \\
\text { no ano } 0\end{array}$ & $\begin{array}{l}\text { Suporte da } \\
\text { área } \\
\text { recuperada } \\
\text { no ano } 1\end{array}$ & $\begin{array}{l}\text { Suporte da } \\
\text { área } \\
\text { recuperada } \\
\text { no ano } 2\end{array}$ & $\begin{array}{l}\text { Suporte da } \\
\text { área } \\
\text { recuperada } \\
\text { no ano } 3\end{array}$ & $\begin{array}{l}\text { Suporte da } \\
\text { área } \\
\text { recuperada } \\
\text { no ano } 4\end{array}$ & $\begin{array}{l}\text { Suporte da } \\
\text { área } \\
\text { recuperada } \\
\text { no ano } 5\end{array}$ & $\begin{array}{l}\text { Suporte da } \\
\text { área } \\
\text { recuperada } \\
\text { no ano } 6\end{array}$ & $\begin{array}{l}\text { Suporte da } \\
\text { área } \\
\text { recuperada } \\
\text { no ano } 7\end{array}$ & $\begin{array}{l}\text { Suporte da } \\
\text { área total da } \\
\text { propriedade }\end{array}$ & $\begin{array}{c}\text { Média em } \\
\text { Ua/ha }\end{array}$ \\
\hline Ano 0 & $149 \mathrm{Ua}$ & $57 \mathrm{Ua}$ & $77 \mathrm{Ua}$ & $77 \mathrm{Ua}$ & $77 \mathrm{Ua}$ & $77 \mathrm{Ua}$ & $77 \mathrm{Ua}$ & $77 \mathrm{Ua}$ & $77 \mathrm{Ua}$ & $743 \mathrm{Ua}$ & 1,024 \\
\hline Ano 1 & $142 \mathrm{Ua}$ & $106 \mathrm{Ua}$ & $55 \mathrm{Ua}$ & $73 \mathrm{Ua}$ & $73 \mathrm{Ua}$ & $73 \mathrm{Ua}$ & $73 \mathrm{Ua}$ & $73 \mathrm{Ua}$ & $73 \mathrm{Ua}$ & $740 \mathrm{Ua}$ & 1,019 \\
\hline Ano 2 & $135 \mathrm{Ua}$ & $135 \mathrm{Ua}$ & $106 \mathrm{Ua}$ & $52 \mathrm{Ua}$ & $69 \mathrm{Ua}$ & $69 \mathrm{Ua}$ & $69 \mathrm{Ua}$ & $69 \mathrm{Ua}$ & $69 \mathrm{Ua}$ & $774 \mathrm{Ua}$ & 1,066 \\
\hline Ano 3 & $128 \mathrm{Ua}$ & $105 \mathrm{Ua}$ & $135 \mathrm{Ua}$ & $106 \mathrm{Ua}$ & $49 \mathrm{Ua}$ & $66 \mathrm{Ua}$ & $66 \mathrm{Ua}$ & $66 \mathrm{Ua}$ & $66 \mathrm{Ua}$ & $787 \mathrm{Ua}$ & 1,084 \\
\hline Ano 4 & $121 \mathrm{Ua}$ & $87 \mathrm{Ua}$ & $105 \mathrm{Ua}$ & $135 \mathrm{Ua}$ & $106 \mathrm{Ua}$ & $47 \mathrm{Ua}$ & $62 \mathrm{Ua}$ & $62 \mathrm{Ua}$ & $62 \mathrm{Ua}$ & $790 \mathrm{Ua}$ & 1,088 \\
\hline Ano 5 & $115 \mathrm{Ua}$ & $80 \mathrm{Ua}$ & $87 \mathrm{Ua}$ & $105 \mathrm{Ua}$ & $135 \mathrm{Ua}$ & $106 \mathrm{Ua}$ & $44 \mathrm{Ua}$ & $59 \mathrm{Ua}$ & $59 \mathrm{Ua}$ & $793 \mathrm{Ua}$ & 1,093 \\
\hline Ano 6 & $110 \mathrm{Ua}$ & $76 \mathrm{Ua}$ & $80 \mathrm{Ua}$ & $87 \mathrm{Ua}$ & $105 \mathrm{Ua}$ & $135 \mathrm{Ua}$ & $106 \mathrm{Ua}$ & $42 \mathrm{Ua}$ & $56 \mathrm{Ua}$ & $799 \mathrm{Ua}$ & 1,101 \\
\hline Ano 7 & $104 \mathrm{Ua}$ & $73 \mathrm{Ua}$ & $76 \mathrm{Ua}$ & $80 \mathrm{Ua}$ & $87 \mathrm{Ua}$ & $105 \mathrm{Ua}$ & $135 \mathrm{Ua}$ & $106 \mathrm{Ua}$ & $40 \mathrm{Ua}$ & $808 \mathrm{Ua}$ & 1,113 \\
\hline
\end{tabular}

Quadro 8 - Capacidade de suporte da propriedade - Projeto 5. Cultivo da soja. Fonte: Dados da pesquisa.

Foram incluídos nos processos indiretos de recuperação e também no sistema direto por meio da gradagem, os custos da implantação da atividade agrícola, devido à necessidade do tratamento do solo, por meio de máquinas pesadas para efetivar a limpeza das áreas. Isso é decorrente do fato de que, a vegetação nativa anterior a pastagem, correspondia a floresta equatorial e por isso, nesmo após a derrubada e a queima da mata, os grandes troncos permanecem no local e seu processo de apodrecimento é lento, as toras permanecem durante anos implicando aumento do custo da recuperação, que só se torna só possível com o auxilio de máquinas de esteira para enleirar todo o material remanescente, e posterior uso de gradagens pesadas para triturar raízes e plantas indesejáveis.

Em muitas regiões do estado de Rondônia e, também, da Amazônia Legal, o solo é formado por rochas sedimentares com muitas áreas de arenito, isso determina a baixa fertilidade e faz-se necessária à descompactação do solo e o provimento de fosfato. A calagem não é muito utilizada, pois a gramínea predominante na maior parte da região é a Brachiaria brizantha - altamente resistente aos baixos níveis de $\mathrm{pH}$ do solo.

No caso dos projetos 3,4 e 5 a calagem não foi necessária, pois o fosfato disponibilizado advém do termofosfato, cuja composição também agrega $20 \%$ de cálcio puro. Assim, unindo essa informação com a do parágrafo anterior, é possível explicar o porquê da não utilização de uma operação específica para a calagem. 
Com relação aos benefícios, nos projetos 3 e 4 foram inseridos nos fluxos de caixa os ganhos, além dos provenientes do rebanho bovino, também aqueles oriundos da produção agrícola de soja e arroz. As produtividades foram condicionadas as médias obtidas nas parcelas experimentais desenvolvidas na Fazenda Nova Vida que correspondem a 35 sacas de $60 \mathrm{~kg} \mathrm{ha}^{-1}$ para o arroz e 39 sacas de $60 \mathrm{~kg} \mathrm{ha}^{-1}$ para a soja.

\subsection{3 "Projeto 6" venda da propriedade e instalação de uma nova através do desmatamento}

Esse projeto parte da hipótese de que o produtor vende a propriedade e toda a infra-estrutura nela contida, incluindo o rebanho, e o capital gerado na transação $\mathrm{R} \$ 1.850 .000,00$ - é totalmente utilizado na compra de uma nova área de terra contendo apenas a mata nativa da região amazônica.

O processo de formação de uma fazenda desde a compra da terra, passando pelas etapas de formação da pastagem, instalação e construção das benfeitorias até a estabilização do rebanho, constituiu, junto com a formação da pastagem, os custos de investimento do projeto. Este projeto foi formalizado nos mesmos moldes que os anteriores e tem a função de avaliar se a substituição de áreas degradadas por áreas brutas para execução do desmatamento é mais rentável que os procedimentos de recuperação.

O montante do capital disponível permitiu que esse projeto pudesse ser elaborado em uma área de 2662 hectares. Considerando o valor de R \$248,00 por hectare (para junho de 2003) o valor da propriedade hipoteticamente adquirida foi de aproximadamente $\mathrm{R} \$ 660.000,00$. Entretanto, para fins dessa pesquisa, levou-se em conta a possibilidade da utilização de $20 \%$ da área, devido a necessidade legal imposta pelo Governo Federal ${ }^{13}$ de manter a área de reserva com o mínimo de $80 \%$ da área total. Dessa forma, a área passível de utilização corresponde a hectares que foram transformados em três anos, ou seja, a cada ano 177,5 hectares de mata foram derrubados, sendo que no terceiro ano o processo foi finalizado. Essa medida foi

\footnotetext{
${ }^{13}$ Atualmente, a taxa de $80 \%$ destinada à área de preservação foi determinada pelo Poder Executivo, e não pelo Legislativo, que utilizou a força de lei da Medida Provisória para alterar a redação do Código Florestal.
} 
instituída devido a restrição do capital disponível, que não permitiria ao produtor desmatar e instalar a infra-estrutura necessária, além de comprar animais para povoar toda a área, em um único ano.

Para o entendimento e a determinação do processo de desmatamento e também da produtividade da pastagem recém formada, foram utilizadas as informações das pesquisas concebidas em Rondônia e nos painéis realizados no Pará e no Mato Grosso, além da revisão de literatura descrita pr Peixoto (1986), Costa (2000) e Aguiar (1998). A Figura 6 procura apresentar, sucintamente, como ocorre o processo de transformação da mata em pastagem.

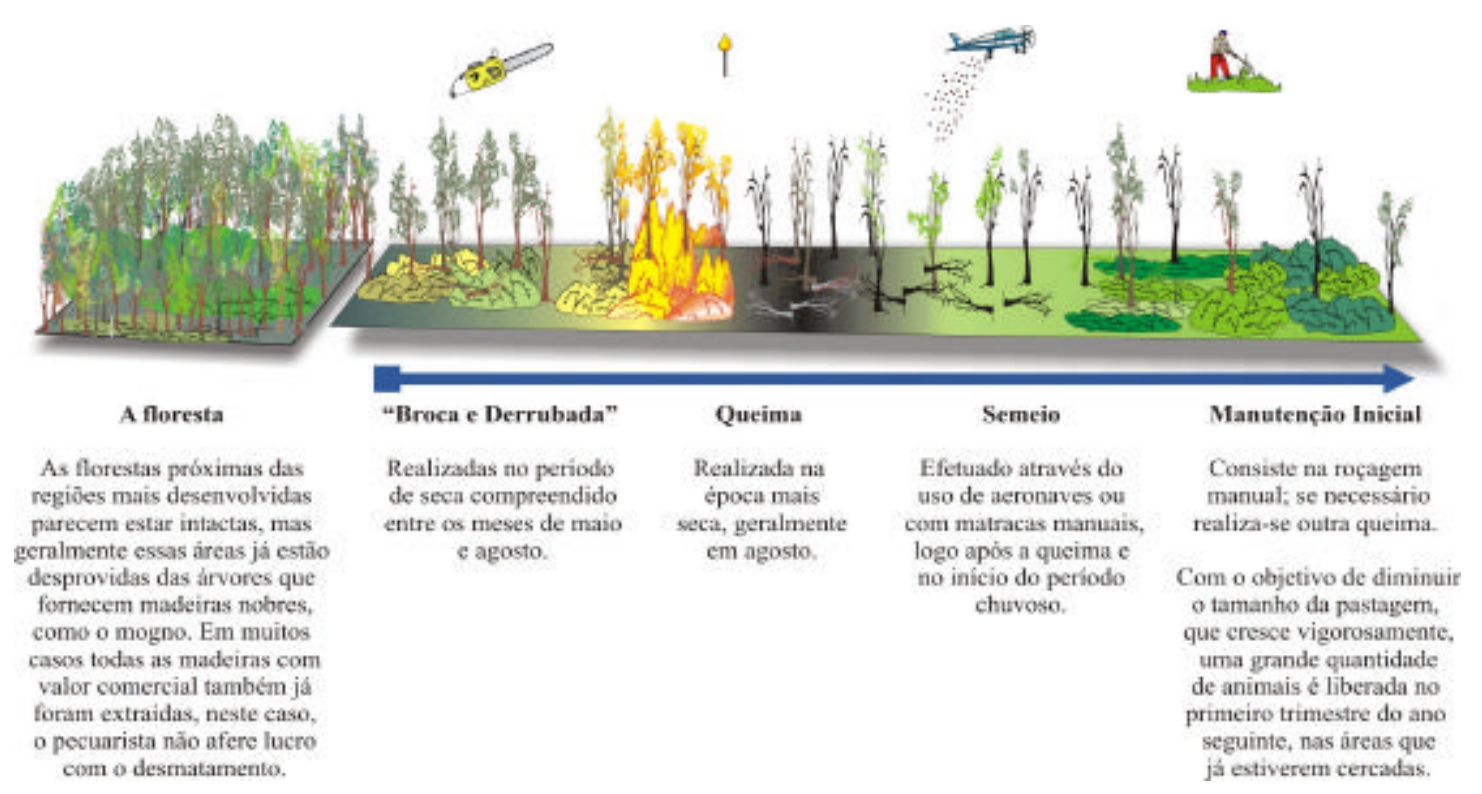

Figura 6 - O processo de formação das pastagens .

\subsubsection{O processo de formação das pastagens}

Inicialmente as áreas florestais são desmatadas através dos processos denominados "broca e derrubada"

\footnotetext{
14 "Broca" termo que denomina aconstrução de estradas e acessos, possibilitando a entrada das equipes com equipamentos para a retirada da madeira que possuir valor comercial. "Derrubada" corresponde ao corte das árvores menores, de cipós e de folhagens que ficam no local e que após secarem servirão de combustível para a realização da queimada.
} 
A queima é realizada no auge da estação de seca de cada região. Em seguida, o semeio distribui sementes da forragem Brachiaria brizanta. Em algumas regiões, utilizam-se $80 \%$ de sementes da braquiária e $20 \%$ do capim tanzânia. O uso dessa mistura visa aproveitar a alta fertilidade das cinzas agregadas ao solo com o capim tanzânia, que é mais produtivo, porém exige maior quantidade de nutrientes. O pasto de tanzânia prevalece por, aproximadamente, um ano, enquanto a fertilidade do solo ainda é alta; com a redução da quantidade de nutrientes disponíveis, a braquiária se impõe como a forrageira dominante. Nesse período inicial, a taxa de lotação, ou seja, a quantidade de animais por hectare é muito alta e permanece em níveis bastante satisfatórios até oito anos após a abertura da mata.

Alguns produtores relataram que nas fases iniciais, a pastagem recém formada pode suportar até 10 cabeças por hectare (cerca de 6,5 UA/ha). Entretanto, os relatos obtidos durante os painéis descreveram números inferiores, por isso os valores utilizados nesta pesquisa iniciam com a média anual de 4 UA/ha com tendência negativa decrescente conforme a Tabela 11 .

Tabela 11. Taxa de lotação por ha - Projeto 6. Estimativa não linear da perda da taxa de lotação por ano.

\begin{tabular}{ccc}
\hline Ano & UA/ha & \% de Redução \\
\hline Ano 0 & - & - \\
Ano 1 & 4,00 & - \\
Ano 2 & 3,20 & $-25,00 \%$ \\
Ano 3 & 2,70 & $-18,52 \%$ \\
Ano 4 & 2,40 & $-12,50 \%$ \\
Ano 5 & 2,15 & $-11,63 \%$ \\
Ano 6 & 2,00 & $-7,50 \%$ \\
Ano 7 & 1,85 & $-8,11 \%$ \\
\hline
\end{tabular}

Fonte: Dados da pesquisa.

Com base na Tabela 11 e sabendo que o processo de formação da pastagem inicia-se em maio e dura cerca de oito meses, a capacidade total de suporte da pastagem constituída nos primeiros oito anos é apresentada no Quadro 9. 


\begin{tabular}{|c|c|c|c|c|c|}
\hline & $\begin{array}{l}\text { Area formada } \\
\text { no ano } 1\end{array}$ & $\begin{array}{l}\text { Area formada } \\
\text { no ano } 2\end{array}$ & $\begin{array}{c}\text { Area formada } \\
\text { no ano } 3\end{array}$ & \multicolumn{2}{|c|}{ Area total de pastagem } \\
\hline Hectares & $177,5 \mathrm{Ha}$ & $177,5 \mathrm{Ha}$ & $177,5 \mathrm{Ha}$ & \multicolumn{2}{|c|}{$726 \mathrm{Ha}$} \\
\hline Anos & $\begin{array}{l}\text { Suporte da } \\
\text { área formada } \\
\text { no ano } 1\end{array}$ & $\begin{array}{c}\text { Suporte da } \\
\text { área formada } \\
\text { no ano } 2\end{array}$ & $\begin{array}{c}\text { Suporte da } \\
\text { área formada } \\
\text { no ano } 3\end{array}$ & $\begin{array}{l}\text { Suporte da } \\
\text { área total da } \\
\text { propriedade }\end{array}$ & $\begin{array}{l}\text { Media em } \\
\text { UA/ha }\end{array}$ \\
\hline $\begin{array}{l}\text { Ano } 0 \\
\text { Ano } 1\end{array}$ & $\begin{array}{c}0 \cup A \\
712 \cup A\end{array}$ & $\begin{array}{l}0 \cup A \\
0 \cup A\end{array}$ & $\begin{array}{l}0 \cup \mathrm{UA} \\
0 \cup A\end{array}$ & $\begin{array}{c}0 \text { UA } \\
712 \text { UA }\end{array}$ & $\begin{array}{l}0,000 \\
1338\end{array}$ \\
\hline Ano 2 & $570 \cup A$ & 708 UA & $0 \cup A$ & 1278 UA & 2,402 \\
\hline Ano 3 & 481 UA & 566 UA & 708 UA & 1755 UA & 3,299 \\
\hline Ano 4 & 427 UA & 478 UA & 566 UA & 1472 UA & 2,766 \\
\hline Ano 5 & 383 UA & $425 \cup A$ & $478 \cup A$ & 1285 UA & 2,416 \\
\hline Ano 6 & 356 UA & 381 UA & 425 UA & 1161 UA & 2,183 \\
\hline Ano 7 & 329 UA & 354 UA & 381 UA & 1064 UA & 2,000 \\
\hline
\end{tabular}

Quadro 9 - Capacidade de suporte da propriedade - Projeto 6. Desmatamento. Fonte: Dados da pesquisa.

As possibilidades de obtenção de ganhos durante a etapa da formação da pastagem não foram consideradas, devido às controvérsias que cercam os assuntos referentes aos ganhos oriundos da extração ilegal de madeiras, o aproveitamento do carvão resultante da queimada e o possível uso da alta fertilidade do solo para cultivo não-mecanizado de produtos agrícolas, como a banana e o arroz, logo após a queima.

As áreas de mata, geralmente estão mais afastadas das áreas desenvolvidas e são vizinhas a outras áreas com a floresta nativa. Isso implica maiores perdas ocasionadas pelo aumento de cerca e $30 \%$ nas taxas de mortalidade do rebanho, devido ao ataque de animais selvagens (grandes felinos e animais peçonhentos). As taxas consideradas nesse projeto foram, portanto, modificadas para 4,0\% (para os animais jovens) e 1,7\% (para os adultos).

As dificuldades de acesso a regiões remotas determinaram o aumento dos gastos relacionados a alguns itens como a construção de pontes e estradas e o uso de combustíveis para a locomoção até os pólos urbanos. 


\subsubsection{Considerações sobre a mão-de-obra}

Os projetos que envolvem os sistemas extensivos de pecuária são bastante sensíveis aos custos depositados na mão-de-obra. Segundo a média resultante dos painéis nos cinco estados pesquisados, os gastos com esse item correspondem, em média, a 28,45\% dos custos de produção efetivos, ou seja, sem incluir as depreciações e a remuneração do capital. Por isso foi necessário buscar meios de se avaliar quais os ganhos de escala envolvidos com a produção animal em relação à otimização da mãode-obra. Para tanto, e seguindo a mesma linha de raciocínio de uso dos resultados dos painéis, o Quadro 10 tem a função de apresentar o uso da mão-de-obra nas propriedades definidas para cada local analisado. É possível verificar no Quadro 10, a quantidade média de unidades animais necessária para justificar a existência de uma unidade de trabalho, tendo como base que uma unidade de trabalho corresponde ao piso salarial mínimo de um trabalhador fixo mensal (vaqueiro ou peão), com acréscimo de $42 \%$, que inclui: o salário, os encargos sociais, férias, $13^{\circ}$ salário, impostos e contribuições. 


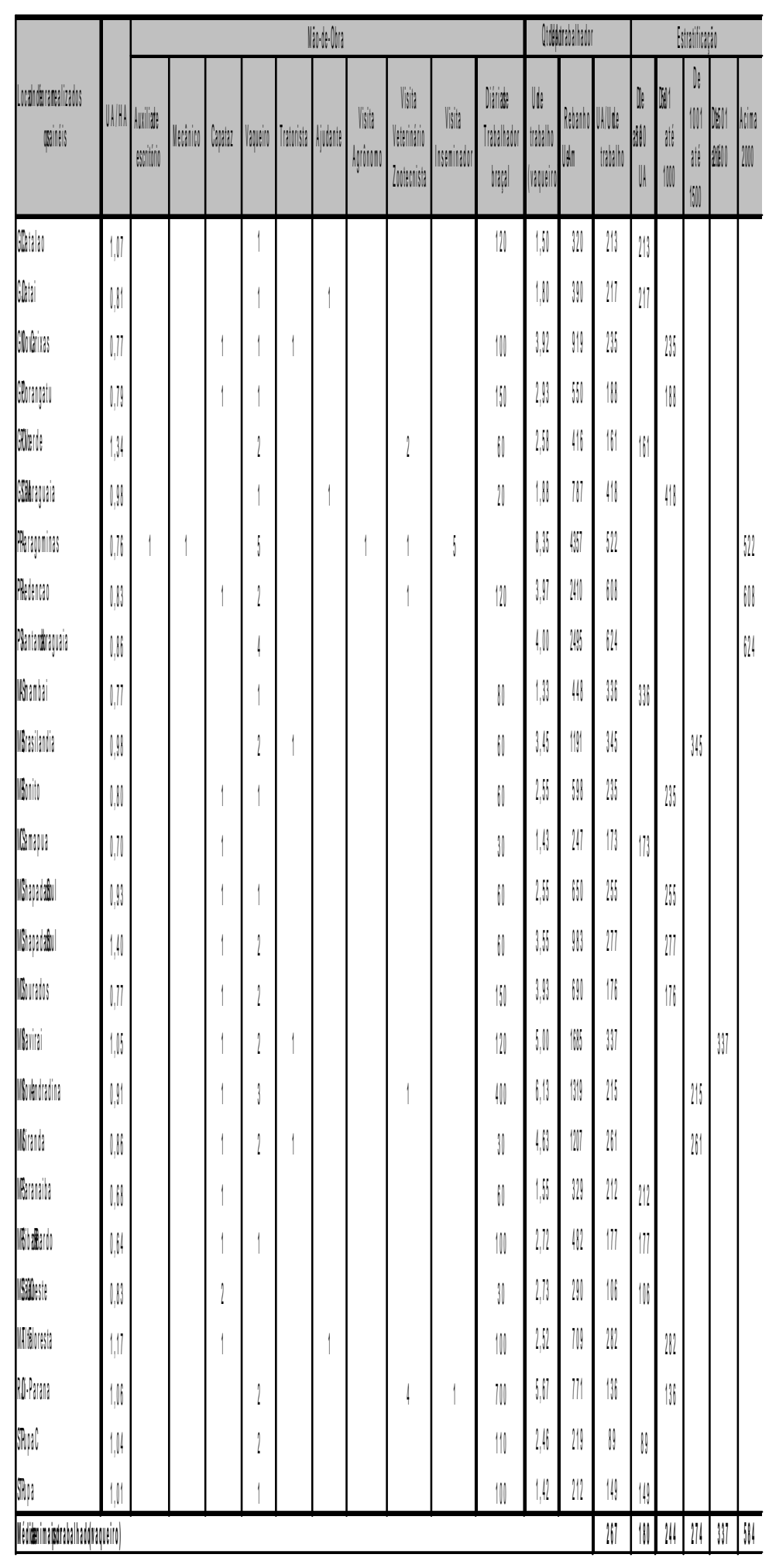

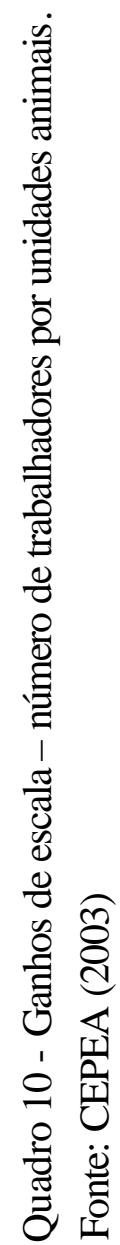


Para transformar os diferentes tipos de cargos em uma única unidade de trabalho foi criada uma medida de ponderação com base no salário referente a cada cargo em relação ao salário de um vaqueiro. As ponderações são explicitadas na Tabela 12, assim tomando como exemplo: o salário de um tratorista é $20 \%$ maior que o de um vaqueiro por isso sua ponderação é dada por 1,2 unidades de trabalho.

Tabela 12. Valores para conversão em unidades de trabalho.

\begin{tabular}{lc}
\hline \multicolumn{1}{c}{ Profissão } & $\begin{array}{c}\text { Unidade de trabalho } \\
\text { para ponderação }\end{array}$ \\
\hline Auxiliar de escritório & 1,200 \\
Mecânico & 1,400 \\
Capataz & 1,300 \\
Tratorista & 1,200 \\
Ajudante & 0,800 \\
Visita Agrônomo & 0,167 \\
Visita Veterinário Zootecnista & 0,167 \\
Visita Inseminador & 0,083 \\
Diárias de Trabalhador braçal & 0,004 \\
Vaqueiro & 1,000 \\
\hline
\end{tabular}

Fonte: Dados da pesquisa.

Na última linha do Quadro 10 é possível averiguar que, em média, para cada 267 unidades animais é necessário uma unidade de trabalho, mas quando as observações são agrupadas é possível notar que a cada 500 unidades as proporções æ̃o alteradas, como esperado de acordo com as economias de escala. Em cada um dos seis projetos, as quantidades de mão-de-obra foram recalculadas conforme os valores dos grupos estratificados nas colunas à direita do Quadro 10 e a quantidade de animais resultantes dos cálculos da evolução do rebanho.

Entretanto, as propriedades listadas no Quadro 10 não refletem o uso dos sistemas agrícolas, com exceção de PA Paragominas, pois são propriedades definidas exclusivamente para a atividade pecuária. Assim, nos projetos 3 e 4 foram incluídos gastos a mais, com assessoria agronômica, devido à necessidade que um pecuarista terá, nos primeiros anos, para efetivar as práticas agrícolas incluídas no seu sistema produtivo. 


\subsubsection{Considerações sobre os cálculos dos custos fixos (depreciações e custo de oportunidade)}

Os valores lançados no fluxo de caixa, que serve de base para os cálculos dos indicadores do desempenho econômico, correspondem à receita gerada pela venda dos produtos e aos custos efetivos - custos efetivamente desembolsados nas atividades.

Os valores de depreciação foram considerados apenas para efeito dos cálculos relativos aos valores residuais de construções, benfeitorias, máquinas, implementos e equipamentos. Segundo Noronha (1987), a idéia do uso da depreciação é útil sob a ótica de dois aspectos principais: no cálculo dos custos de produção para fins de previsões orçamentárias e na análise de projetos quando é necessário determinar o lucro tributável e os valores residuais quando o projeto é encerrado.

Nos fluxos de caixa referentes a todos os projetos, não é considerada a incidência do imposto de renda, por isso não foi necessário determinar o lucro tributável. A maioria dos valores residuais não foi calculada por meio das formulações utilizadas para cálculo da depreciação. Tais valores, assim como os valores dos bens no início dos projetos, foram obtidos por meio dos painéis. Nos demais casos, utilizou-se a fórmula da depreciação linear a fim de estimar os valores residuais.

Quanto aos custos de oportunidade, o capital referente à terra e a todos os bens (construções, máquinas, implementos e equipamentos) foram considerados como custos de investimento e por isso não foi necessário estimar o custo de oportunidade desses subitens .

\subsubsection{Considerações sobre os cálculos de horas trabalhadas por máquinas}

Em alguns projetos, foi considerado, nos custos das operações destinadas a recuperar a pastagem, o valor da hora máquina. Para isso, a fórmula empregada levou em consideração apenas o consumo do óleo diesel, visto que a depreciação não foi considerada nos custos operacionais, conforme o disposto no subitem anterior, e, também, porque o valor destinado àmanutenção de máquinas e implementos foi lançado a parte, conforme o subitem 2.1.5 do Anexo B. 
A fórmula para cálculo da hora máquina é dada por:

$V H M=(H P * 0,12) * P D$

Sendo:

$V H M$ - valor hora máquina

$H P$ - quantidade de cavalos vapor

$P D$ - preço do diesel

0,12 - coeficiente para conversão para determinar o consumo de combustível através da potência.

\subsection{Análises}

A avaliação econômica utilizada baseia-se nos métodos bastante difundidos da análise de projetos. Cita-se como exemplo a literatura produzida por Contador (1981), Pomeranz (1985), Noronha (1987) e Buarque (1991). Tais autores ressaltam a importância de se realizar cálculos de indicadores da viabilidade econômica dos pojetos em ambiente determinista e de risco.

$\mathrm{Na}$ análise determinista, os valores utilizados no cálculo do fluxo de caixa são fixos, o que facilita a análise, mas condiciona o estudo a pressuposições muito fortes com relação à constância dos preços de insumos e produtos e à produtividade ao longo do tempo. Sabe-se, no entanto, que as unidades de produção agropecuárias, na maioria dos casos, estão sujeitas a adversidades econômicas e climáticas. Por isso, o conhecimento das variáveis que afetam o processo produtivo e a comercialização é incerto. Como proposta para amenizar esse problema, a análise em condições de risco, utiliza métodos que possibilitam a incorporação das incertezas, tornando as avaliações mais realistas.

\subsubsection{Avaliação econômica determinista}

Através das informações obtidas na etapa anterior, foi constituída uma propriedade agrícola representativa, na qual se desenvolveram os programas de intensificação propostos. Cada tratamento foi avaliado como um projeto de investimento, sendo calculados os fluxos de despesas e receitas ao longo de um espaço temporal de oito anos. 
O fluxo de caixa obtido em cada um dos seis projetos serviu de base para os cálculos dos principais indicadores de análise de desempenho econômico.

A seguir, são demonstrados as expressões matemáticas e os problemas vinculados aos indicadores utilizados nas análises. Para descrever as vantagens e desvantagens dos critérios de análise escolhidos, utilizou-se como base os trabalhos realizados por Buarque (1991), Noronha (1987) e Azevedo Filho (1988).

\subsubsection{Valor Presente Líquido (VPL)}

Corresponde à soma algébrica dos valores do fluxo de caixa do projeto, atualizados a uma determinada taxa de juros.

Apresentação matemática:

$$
V P L=\sum_{i=0}^{n} \frac{\left(B_{i}-C_{i}\right)}{(1+j)^{i}}
$$

Sendo:

$B_{i}$ - fluxo de benefícios em unidade monetária no ano i.

$C_{i}$ - fluxo de custos em unidade monetária no ano i.

$j$ - taxa de juros.

$n$ - vida útil do projeto

O projeto é considerado viável se o VPL for positivo. Em condições deterministas, este indicador é o mais consistente, pois tem menor número de limitações. No entanto, pode haver dificuldades para determinar o valor exato da taxa de juros a ser utilizada, sendo esse o principal problema quanto ao uso do VPL. Para tanto, utiliza-se o custo de oportunidade do capital investido, ou seja, qual a taxa de rentabilidade que o capital pode ter na melhor alternativa de utilização, além do projeto.

O VPL considera a escala do projeto, mas nada pode ser aferido quanto à duração do projeto. Por isso, a interpretação desse critério deve ser cautelosa de forma a avaliar os resultados dos outros indicadores. 


\subsubsection{Taxa Interna de Retorno (TIR)}

É a taxa de juros que iguala a zero o valor presente líquido do projeto

Apresentação matemática:

$$
\sum_{i=0}^{n} \frac{\left(B_{i}-C_{i}\right)}{(1+j)^{i}}=0
$$

Sendo:

$B_{i}$ - fluxo de benefícios em unidade monetária no ano i.

$C_{i}$ - fluxo de custos em unidade monetária no ano i.

$n$ - vida útil do projeto

$j-$ TIR

O projeto é considerado viável se a TIR for igual ou superior ao custo de oportunidade dos recursos de sua implantação. A priori, o valor da TIR corresponde diretamente ao custo de oportunidade do projeto, mas está sujeito a resultados controversos e soluções múltiplas nos casos em que o fluxo de caixa não segue o padrão do "tipo convencional". O convencional é representado por valores líquidos negativos na fase inicial e apenas valores positivos são verificados nas fases posteriores, ou seja, a mudança de sinal é verificada apenas uma vez. Caso ocorra mais de uma mudança de sinal, a aplicabilidade da TIR deverá ser cautelosa, devido às limitações impostas pela expressão matemática. Outro fator limitante decorre do fato de que a TIR pode ser utilizada em situações pouco realistas, nas quais os projetos devam ser mutuamente exclusivos, além do que as grandes diferenças entre os valores de investimento também não são contempladas.

\subsubsection{Relação Benefício Custo (RBC)}

É a razão da soma algébrica dos benefícios em relação à dos custos, atualizados a uma determinada taxa de juros. 
Apresentação matemática:

$$
R B C=\frac{\left(\sum_{i=0}^{n} \frac{B_{i}}{(1+j)^{i}}\right)}{\left(\sum_{i=0}^{n} \frac{C_{i}}{(1+j)^{i}}\right)}
$$

Sendo:

$B_{i}$ - fluxo de benefícios em unidade monetária no ano i.

$C_{i}$ - fluxo de custos em unidade monetária no ano i.

$j$ - taxa de juros.

$n$ - vida útil do projeto

O projeto é considerado viável se a RBC for superior ao valor 1. Essa é a grande vantagem desse indicador: a interpretação relativamente fácil.

No ambiente de decisão, o projeto é descartado imediatamente, caso seja verificado a condição: $\mathrm{RBC}<1$ (caso em que os custos superam os benefícios). Assim como no VPL, a RBC é bastante sensível à taxa de juros e insensível à duração do projeto, bem como à escala do projeto.

\subsubsection{Prazo para a recuperação do capital ou "Pay Back"}

Determina o tempo necessário para tornar nula ou positiva a soma algébrica do fluxo de caixa, podendo ou não atualizar o fluxo a uma determinada taxa de juros.

Apresentação matemática:

Período de recuperação do capital não atualizado (PRC)

$$
\begin{aligned}
& F_{i}=B_{i}-C_{i} \\
& \text { PRC }=k \\
& \text { tal que } \sum_{i=0}^{k} F_{i} \geq 0 \text { e } \sum_{i=0}^{k-1} F_{i}<0
\end{aligned}
$$


Período de recuperação do capital atualizado (PRCA)

$$
\begin{aligned}
& F_{i}^{\prime}=\frac{\left(B_{i}-C_{i}\right)}{(1+j)^{i}} \\
& P R C A=k a \\
& \text { tal que } \sum_{i=0}^{k a} F_{i}^{\prime} \geq 0 \text { e } \sum_{i=0}^{k a-1} F_{i}^{\prime}<0
\end{aligned}
$$

Sendo:

$B_{i}$ - fluxo de benefícios em unidade monetária no ano i.

$C_{i}$ - fluxo de custos em unidade monetária no ano i.

$F_{i}$ - fluxo líquido não atualizado

$F^{\prime}{ }_{i}$ - fluxo líquido atualizado

$j$ - taxa de juros.

O projeto é considerado viável se a PRC ou PRCA forem menores que o tempo estimado de duração do projeto (n). É um indicador auxiliar que determina o tempo necessário para a recuperação do capital investido Sua interpretação pode ser errônea quando houver múltiplas mudanças de sinal no fluxo de caixa líquido, assim como observado na TIR. No caso do PRCA, o resultado também expressa grande sensibilidade ao valor que caracteriza a taxa de juros.

\subsubsection{A utilização conjunta dos indicadores}

Devido às características complementares que um indicador tem em relação ao outro, os resultados dos cálculos de cada um dos critérios em cada projeto foram posicionados apresentados em quadros e gráficos comparativos para facilitar a discussão.

Diante das observações feitas para cada indicador de análise econômica, pode-se concluir que as restrições, declaradas anteriormente, não impedirão o uso de expressões algébricas anteriormente descritas, pois foram assumidos os seguintes métodos e proposições:

i) o horizonte de tempo foi igual para todos os projetos;

ii) os projetos foram considerados, em primeira análise, mutuamente exclusivos; 
iii) foram analisados os fluxos de caixa e as informações exógenas aos cálculos referentes ao projeto, em todos os projetos procurourse manter um padrão único para entradas e saídas de capital;

iv) as quantias de investimento destinadas aos diferentes projetos não foram totalmente equivalentes, nos projetos 1 e 2 (sem alterações e com a aplicação de adubo e herbicidas, respectivamente) as quantias de investimento foram menores que os níveis de capital disponível para os projetos 3, 4, 5 e 6, que se equivaleram. Entretanto os valores que diferenciaram os projetos não ultrapassaram o limite de $10 \%$ do valor total da propriedade definida como padrão.

Em etapa posterior aos cálculos dos indicadores apresentados até aqui, foi realizada a análise de sensibilidade, a fim de determinar o impacto que um erro ou modificação de cada uma das variáveis teria nos resultados finais do projeto, no ambiente determinista.

A análise de sensibilidade observou a variação que ocorre na rentabilidade do projeto em função de uma mudança em cada uma de suas variáveis, mantendo-se as outras constantes, isso permitiu conhecer a importância econômica de cada insumo ou produto sobre o desempenho da empresa rural.

Conforme descrito por Buarque (1991), a análise é dada pela seguinte formulação:

$$
r=\frac{R-C}{I}
$$

Sendo:

$$
\begin{aligned}
& R=p_{1} \cdot q_{1}+p_{2} \cdot q_{2}+\ldots+p_{n} \cdot q_{n} \\
& C=C_{1}+C_{2}+\ldots+C_{m} \\
& r=\text { rentabilidade do investimento } \\
& R=\text { soma dos benefícios; } \\
& C=\text { soma dos custos; } \\
& I=\text { valor total do investimento; } \\
& p_{n}=\text { preço do fator } n ; \\
& q_{n}=\text { quantidade do fator } n ; \\
& C_{n}=\text { custo do insumo } m ;
\end{aligned}
$$


Para uma variação de $p_{n}, q_{n}$ ou $C_{m}$, mantendo-se constante as outras variáveis, teve-se $r^{\prime}$ e a diferença $\left(\Delta r=r-r^{\prime}\right)$ ordenou a importância da variável modificada.

\subsubsection{Avaliação econômica sob condições de risco}

Os elementos que afetaram significativamente os resultados de cada projeto, diagnosticados na análise anterior, foram estudados com maior profundidade através a avaliação de suas séries históricas e foram considerados como aqueles que têm maior influência sob o risco ao qual estão inseridos os projetos.

Para vincular as análises às condições de risco, muitos métodos colocam como necessária a determinação de distribuições de probabilidades, que estariam associadas a cada um dos itens definidos anteriormente. Quando inseridas nos cálculos matemáticos, as distribuições tendem a associar o comportamento real de cada variável ao problema e, como resultado, novas distribuições, referentes aos próprios indicadores de viabilidade dos projetos, seriam obtidas e subsidiariam o processo de escolha dos projetos mais adequados.

Para viabilizar esse processo, novas séries de preços seriam criadas através da geração de números aleatórios, estando, porém condicionadas às distribuições prédefinidas. Isso permitiria promover um número bastante grande de simulações que representariam diversos cenários, criados a partir das variações dos preços de insumos e produtos.

\subsubsection{O método de Simulação de Monte Carlo}

O procedimento, anteriormente descrito, é a base do método quantitativo de simulação denominado Método de Monte Carlo, cuja técnica tem como objetivo a determinação de situações econômicas alternativas através da projeção de valores ao acaso, mas dentro dos limites impostos pelas distribuições das variáveis relevantes, segundo Noronha (1987) e Azevedo Filho (1988) que citam o que foi proposto por Hertz $(1964)^{15}$.

\footnotetext{
${ }^{15}$ HERTZ, O.B. Risk analysis in capital investiment. Havard Business Review, v.42, n.1, p.95-106, Jan./Feb. 1964.
} 
Essa técnica de simulação consiste na seguinte sequiência de cálculos:

i) identificar as variáveis relevantes do fluxo de caixa do projeto e associálas a distribuições de probabilidade, conforme as análises de sensibilidade descritas anteriormente;

ii) determinar aleatoriamente o valor de cada variável, respeitando as suas distribuições;

iii) calcular o valor dos indicadores de desempenho para cada número aleatório obtido na etapa anterior;

iv) repetir o processo até que se obtenha uma confirmação adequada da distribuição de frequiência do indicador de desempenho.

A observação dessa rotina permite inferir que, dentre os métodos que utilizam a probabilidade na análise de risco, o Método de Monte Carlo é o mais simples e pode ser realizado com noções introdutórias de estatística. Devido ao uso dos serviços proporcionados pela computação, esse método se tornou bastante difundido e utilizado em diversos trabalhos que visaram àincorporação de riscos.

Embora a operacionalização do método seja simples, dois problemas devem ser destacados. O primeiro refere-se à etapa da definição das distribuições de probabilidade. Em muitos casos é difícil determinar algebricamente as funções das distribuições dos preços dos produtos de maior relevância.

Para contornar esse tipo de problema muitos trabalhos assumem como proxy das distribuições de preços: a distribuição normal - tendo como base o teorema dos grandes números - ou as distribuições triangulares.

As distribuições triangulares facilitam os cálculos, devido à necessidade de definição de funções lineares condicionada a apenas três valores: o mínimo, o máximo e o valor modal da série histórica em estudo.

As alternativas anteriores pressupõem hipóteses bastante fortes, condicionando os cálculos a possíveis erros nas análises subseqüentes. Segundo Azevedo Filho (1988), o cuidado com o processo de obtenção das distribuições é uma etapa fundamental nas análises de incerteza, pois delas derivarão todos os resultados. 
O segundo ponto a ser discutido é a obtenção de valores ao acaso, mesmo que esses números sejam criados de forma randômica respeitando os limites de distribuições pré-determinadas corretamente, uma complexidade maior seria encontrada nas relações de interdependência entre as variáveis, ou seja, a covariância entre alguns insumos não é nula. Cita-se o exemplo da relação entre o sal mineral para suplementação alimentar bovina e dos fertilizantes, que possuem o fosfato em suas composições, ambos, embora sejam utilizados para fins distintos, têm correlação de preços devido a sua associação com o ácido fosfórico necessário na tecnologia de produção dos dois produtos. Nesse caso a distribuição dos preços desses insumos não podem ser consideradas isoladamente.

Dessa forma, nota-se que o uso do método da simulação de Monte Carlo, neste estudo, torna-se bastante complexo. Além disso, outro aspecto relevante nessa análise é o motivo de existirem muitas variáveis a serem estudadas, pois derivam de seis projetos, acarretando na necessidade de busca de várias séries de preços históricos, das quais algumas não são efetivamente longas a ponto de possibilitar a consolidação de distribuições contínuas de probabilidade.

\subsubsection{A forma alternativa de simulação}

Diante dessas questões o método de Monte Carlo foi descartado para os cálculos de avaliação dos projetos em condições de risco. A forma alternativa utilizada neste estudo, que aparentemente visa tratar dos problemas anteriores, baseou-se na realização de simulações em cenários que realmente ocorreram nos últimos cinco anos. Foram criados diversos cenários sendo que, em cada um, obtiveram-se as informações através de análises deterministas.

Para isso, foram calculados todos os índices para os seis projetos em todos os meses, correspondendo a 66 observações que agregaram a variação simultânea de 32 itens compostos por insumos, produtos, terra e trabalho, conforme o Quadro 11.

As séries históricas de preços são provenientes das instituições: Centro de Pesquisas Avançadas em Economia Aplicada - Esalq / USP - Cepea, Fundação Getúlio Vargas - FGV, Instituto de Economia Agrícola - SP - IEA e Instituto de Pesquisa Econômica Aplicada - IPEA. 


\begin{tabular}{|c|c|c|}
\hline $\mathbf{N}$ & Item & Instituicão \\
\hline 1 & Terra Pasto_RO & FGV \\
\hline 2 & Terra Lavoura_RO & FGV \\
\hline 3 & Terra Mata_RO- & FGV \\
\hline 4 & Boi Gordo_RO & Cepea \\
\hline 5 & Bezerro_RO & Cepea \\
\hline 6 & Vaca Gorda_RO & Cepea \\
\hline 7 & Vacina Febre Aftosa & Cepea/IEA \\
\hline 8 & Sal mineral & Cepea/IEA \\
\hline 9 & Trabalho capataz_RO & FGV \\
\hline 10 & Trav Eventual_RO & FGV \\
\hline 11 & Oleo diesel & Cepea/IEA \\
\hline 12 & Soja - MT & FGV \\
\hline 13 & Arroz Casca-RO & FGV \\
\hline 14 & Termofosfato & IEA \\
\hline 15 & DAP & Cepea \\
\hline 16 & Sulfado de Amonio & Cepea/IEA \\
\hline 17 & Super Simples & Cepea/IEA \\
\hline 18 & Semente de Soja & IEA \\
\hline 19 & Semente de Arroz & IEA \\
\hline 20 & Fertilizante 20_05_20 & IEA \\
\hline 21 & Fertilizante 4-14-08 & IEA \\
\hline 22 & Ivomec & Cepea/IEA \\
\hline 23 & Tordon 2.4 D & IEA \\
\hline 24 & Triatox & IEA \\
\hline 25 & Ripercol injetavel & IEA \\
\hline 26 & Round Up & IEA \\
\hline 27 & Scepter & IEA \\
\hline 28 & Ambush $500 \mathrm{CE}$ & IEA \\
\hline 29 & Agrovet & IEA \\
\hline 30 & Vacina contra carbunculo sintomatico & Cepea/IEA \\
\hline 31 & Arame Ovalado & Cepea \\
\hline 32 & Arame Farpado & Cepea \\
\hline 33 & Burro Domado & IPEA \\
\hline
\end{tabular}

Quadro 11 - Séries utilizadas nas simulações. Fonte: Dados da pesquisa.

No Quadro 11, cada item está relacionado com sua fonte, para os itens que são compostos por duas instituições, foi extraída a média das variações. Nos casos das séries de terra e trabalho da FGV a variação dos valores deu-se de forma semestral, em virtude a frequiência da série histórica.

Todos as séries foram deflacionadas a valores reais pelo IGP-FGV (utilizando junho de 2003, como o último mês de referência). Para todas as séries, foram criados índices de variação mensal, também, com a base fixada no mês de Junho de 2003, e os índices foram então multiplicados pelos preços observados no estado Rondônia.

Com a utilização desse método, espera-se não ter ignorado as correlações existentes entre os preços de insumos e produtos, possibilitando a criação de distribuições discretas da freqüência dos indicadores calculados. Entretanto, o número de simulações ficou restrito ao número de observações, essa é a principal falha desse 
tipo de análise, fato que seria suprido caso fossem realizadas as simulações de Monte Carlo.

Espera-se que as distribuições dos indicadores da viabilidade de econômica dos projetos, formadas através das análises deterministas, aprimorem os resultados do estudo, em vista dos cenários reais às quais as análises estariam submetidas nos últimos 66 meses.

\subsection{Instrumental utilizado para formação dos fluxos de caixa e da promoção das análises}

Para obtenção dos fluxos de caixa dos projetos avaliados neste estudo, foi necessária a construção de uma planilha eletrônica utilizando os recursos do aplicativo Microsoft Excel 2002, em conjunto com o editor de programação Visual Basic for Aplications - Microsoft.

Um único tipo de planilha foi utilizado na elaboração de todos os projetos, a cópia da planilha está disponibilizada no CD-ROM que acompanha este trabalho e todas as instruções de uso necessárias para sua compreensão estão apresentadas no Anexo B.

Os valores referentes à manutenção de benfeitorias, máquinas, implementos, pastagem, rebanho e os demais custos operacionais foram classificados e dispostos mensalmente para o horizonte temporal de análise. Os dados de entradas e saídas de capital (preços e quantidades determinantes dos custos, receitas residuais adotados no fim do projeto), que foram posicionados no fluxo de caixa mensal, podem ser consultados nas planilhas respectivas a cada um dos seis projetos existentes no interior da pasta "Projetos" contida no CD-ROM anexo. Para uso das planilhas é necessário consultar o Anexo B.

Para ajustar a estrutura de composição do rebanho bovino, para cada projeto, condicionando aos índices zootécnicos (Tabela 2 e Tabela 3) e as restrições determinadas pelo limite máximo da pastagem (Tabela 6, Quadro 5, Quadro 6, Quadro 7, Quadro 8 e Quadro 9), foi criada uma rotina de programação para cálculo da evolução do rebanho, que é apresentada no subitem a seguir. 


\subsection{A rotina de programação para cálculo da evolução do rebanho}

Para compreender como foram realizados os cálculos da evolução do rebanho foi criada uma série de figuras apresentadas de forma seqüencial. A Figura 7 apresenta a simbologia utilizada na construção dos fluxogramas - conjunto de operações ordenadas para efetivar os cálculos necessários. As figuras conseguintes apresentam propriamente, os fluxogramas, sendo que o fluxo da Figura 8 é o principal e os fluxos das Figura 9 e Figura 11 são sub-rotinas do fluxograma principal. As Figura 10 e Figura 12 por sua vez correspondem a sub-rotinas iniciadas nos fluxos das Figura 9 e Figura 11, respectivamente.

Os fluxos, entretanto, são úteis apenas para visualização de como os cálculos foram conduzidos. Para saber onde os dados, que alimentam as rotinas da programação, devem ser inseridos é necessário utilizar as instruções do Anexo B, a partir do subitem 2.6.

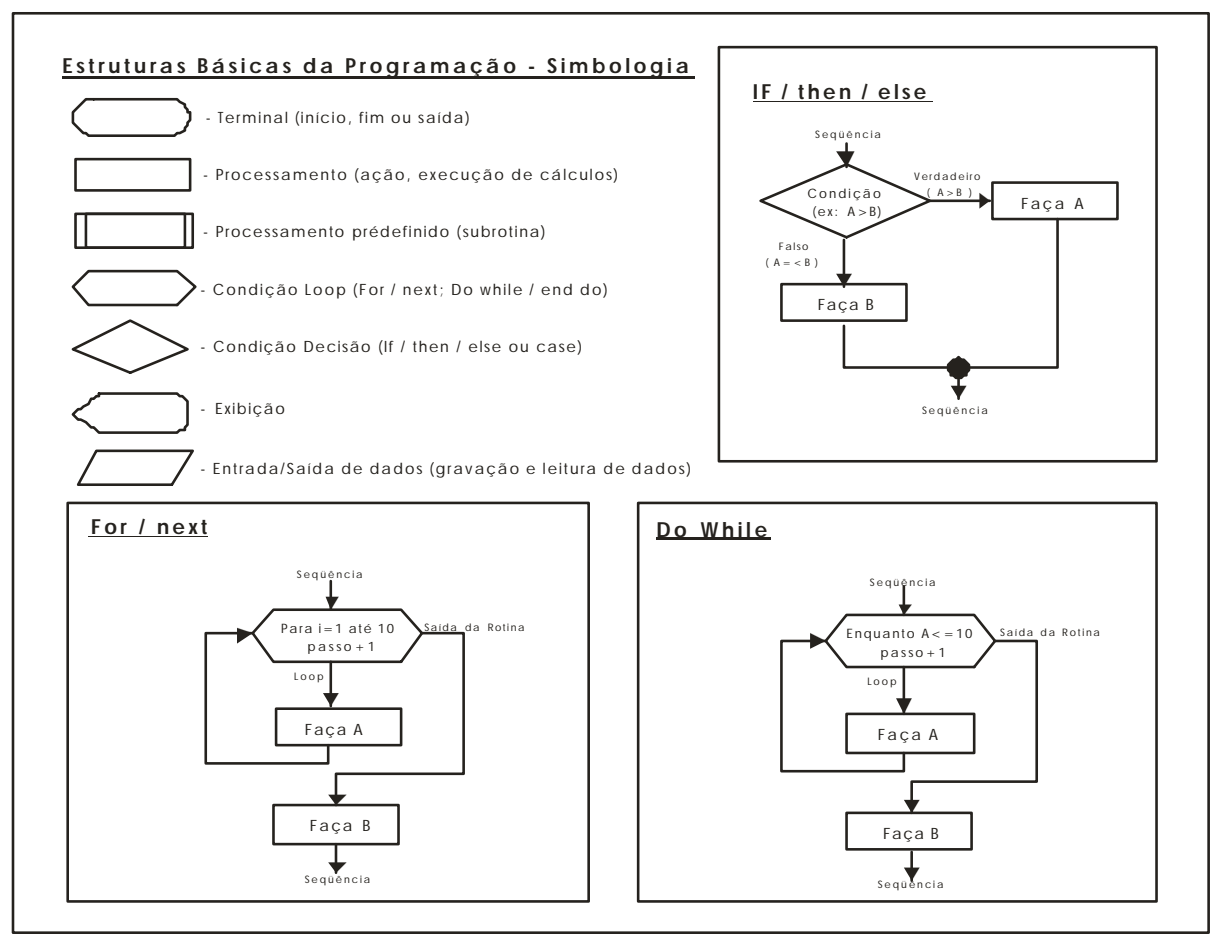

Figura 7 - Simbologia da programação. 
Os fluxogramas a seguir não contêm todas as operações utilizadas para a efetivação dos cálculos, apenas as passagens mais importantes foram apresentadas. Não foram declaradas as rotinas específicas destinadas a viabilizar as operações nos comandos delimitados pelas planilhas do Excel e comandos do VBA - Microsoft.

O fluxograma principal (Figura 8) demonstra a busca dos lotes, previamente inseridos pelo usuário conforme o item 2.1.6.2 do Anexo B. Cada lote pode ser composto por um ou mais animais. Os lotes devem ser formados por animais de mesmo sexo, dentro de uma mesma faixa de peso, adquiridos em um determinado mês dentro do horizonte de tempo pré-determinado. Se o lote já existir na propriedade, então o valor correspondente aos animais será incluído no fluxo de caixa como patrimônio inicial, caso os animais sejam adquiridos, o valor da compra do lote é lançado no fluxo de caixa como custo de acordo com o preço do bezerro, bezerra, novilho, novilha, arroba de vaca ou boi.

No caso das fêmeas segue-se a sub-rotina "Evolução F" e dos machos a subrotina "Evolução M", entretanto, esse mecanismo não aborda os lotes de touros utilizados para a reprodução. Para esses animais são adotados cálculos separados junto com os cálculos dos animais de trabalho, por isso a descrição dos lotes desses animais é realizada conforme o subitem 2.1.6.3 do Anexo B.

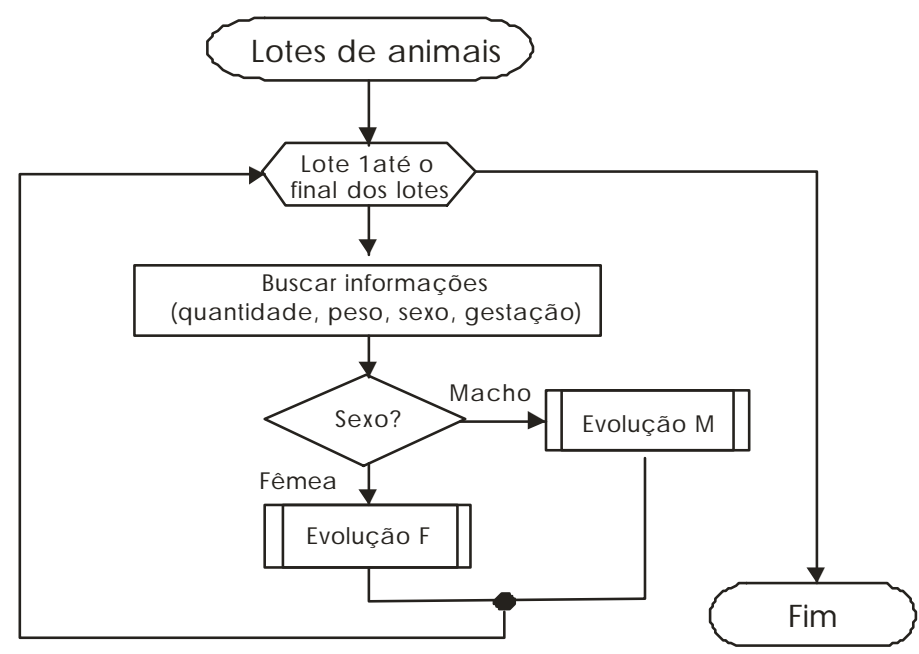

Figura 8 - Fluxograma principal 
Na Figura 9, os dois comandos de Loop iniciais têm como função fazer com que todas as ações posteriores sejam executadas mês a mês, para todos os anos restantes.

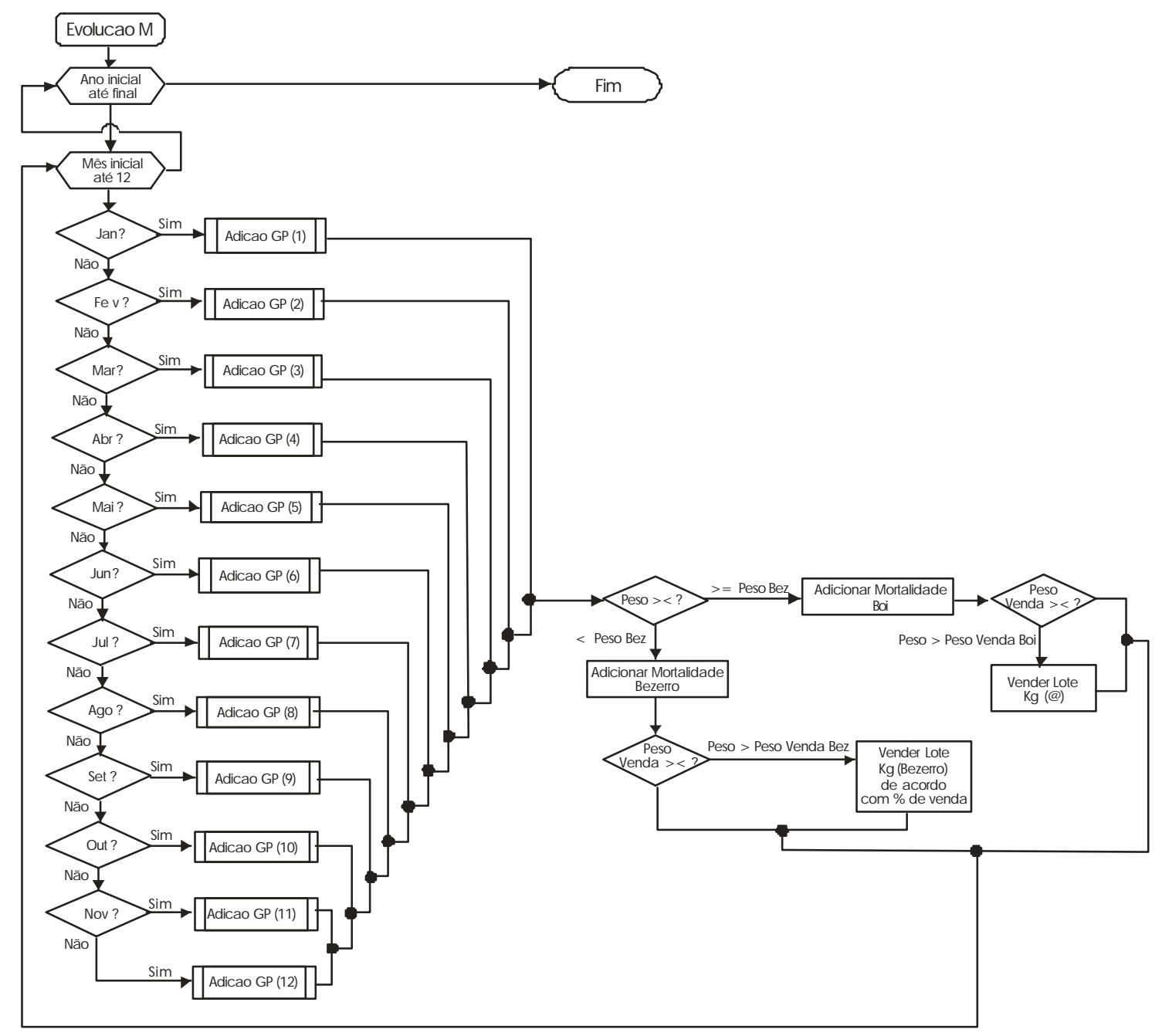

Figura 9 - Sub-rotina "Evolução M".

A cada mês os animais ganham peso de acordo com a sazonalidade e a categoria ao qual o lote pertence. A sub-rotina "AdiçãoGP" (Figura 11) utiliza os dados inseridos (segundo o que é descrito no Grupo de dados 3 do subitem 2.1.6.1, no Anexo B) para adicionar peso aos animais do lote. A seguir, voltando para a Figura 9, extrai-se do número de total de animais do lote a quantidade de animais mortos por mês conforme a taxa de mortalidade (Grupo de dados 1 do subitem 2.1.6.1, no Anexo B). Depois, é 
executada a venda automática do lote caso o peso exceda o peso mínimo para a venda, tanto para o caso dos bezerros (respeitando a proporcionalidade das vendas, também determinada no Grupo de dados 1) como no caso dos bois.

Nessa rotina optourse por deixar que a venda seja consolidada de forma automática, entretanto é importante destacar que em situações reais o produtor poderia ter a opção de vender os animais antes ou depois da data em que os animais atinjam o peso de venda, conforme a sua estratégia de vendas diante das épocas de entressafra.

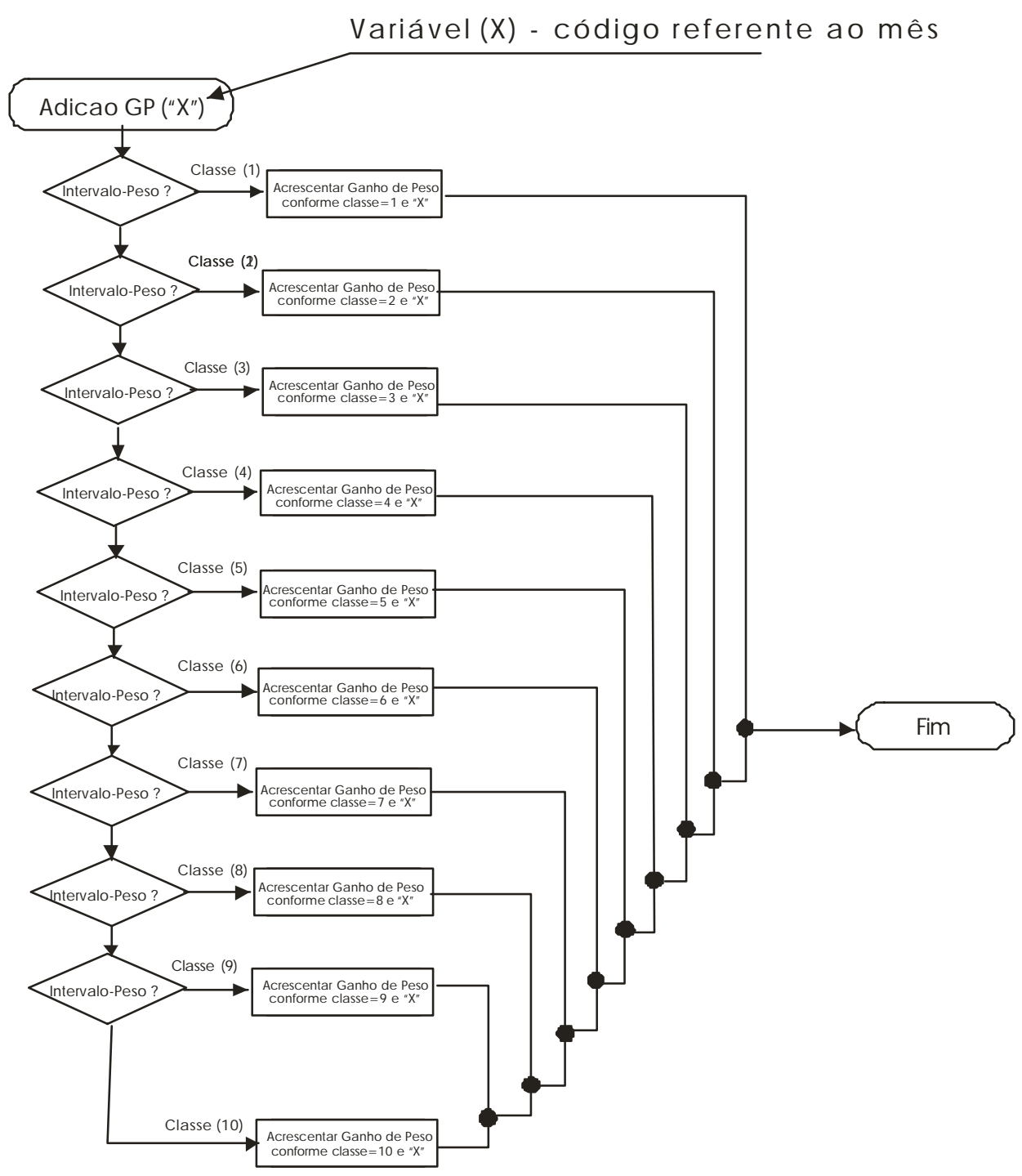

Figura 10 - Sub -rotina "Adição GP". 
A sub-rotina "Evolução F' compreende as mesmas etapas da sub-rotina "Evolução M" utilizando-se da "Adição GPF" (Figura 12) ao invés da "Adição GP". Entretanto, comparando as Figura 9 e Figura 11, nota-se que existem ações adicionais no fluxograma da "Evolução $F$ " que correspondem à etapas reprodutivas e a projeção de nascimentos de bezerros e bezerras. A parição por parte dos lotes de fêmeas é determinada pela variável "G" que têm como limite de meses máximo o vlor dado pelo Intervalo Entre Partos (IEP - determinado no Grupo de dados 1, subitem 2.1.6.1. Anexo B). Para as fêmeas que não atingiram o peso de cobertura, a variável " $G$ ” é sempre nula. Quando o peso médio dos lotes de fêmeas superam o peso de cobertura o valor de "G" é acrescido de uma unidade a cada mês. Ao atingir o peso de cobertura, presume-se que a concepção é realizada, iniciando-se a gestação. Exemplificando, se um lote de fêmeas atingiu o peso de cobertura em janeiro do ano 1 , em março, o valor de "G" para esse lote será 2.

Quando "G" for igual a 9 (nono mês de gestação) a parição é efetuada respeitando o índice da taxa de parição. Assim dois lotes novos são criados automaticamente $\mathbf{e}$ acordo com as percentagens de nascimento de machos e de fêmeas, sendo que esses lotes também seguirão as rotinas da programação. Nos meses seguintes após a parição, o valor de "G" continua a ser acrescido em uma unidade por mês. Se "G" for igual a "MD" (Mês de descarte no ciclo) um percentual das vacas do lote será descartado através da venda pelo peso por arroba de vaca. Quando " $G$ ” atinge o valor do IEP o ciclo é terminado e o valor de "G" volta a ser zero. 


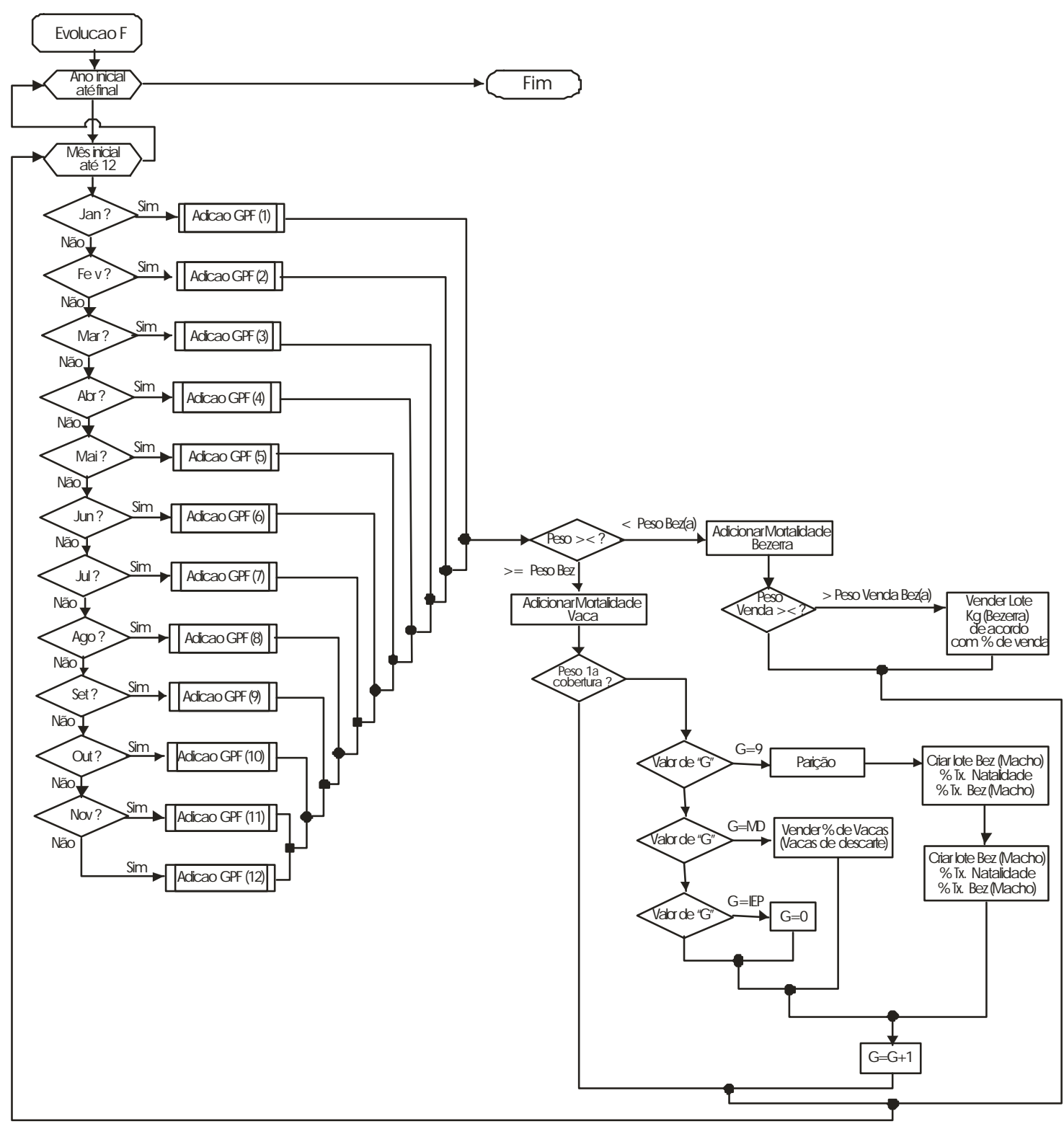

Figura 11 - Sub-rotina "Evolução F".

Todas as taxas (parição, descarte de vacas, percentagem de nascimento de machos e fêmeas) e os valores de IEP, MD, arroba da vaca devem ser determinados conforme apresentado no Grupo de dados 1, subitem 2.1.6.1. do Anexo B. 


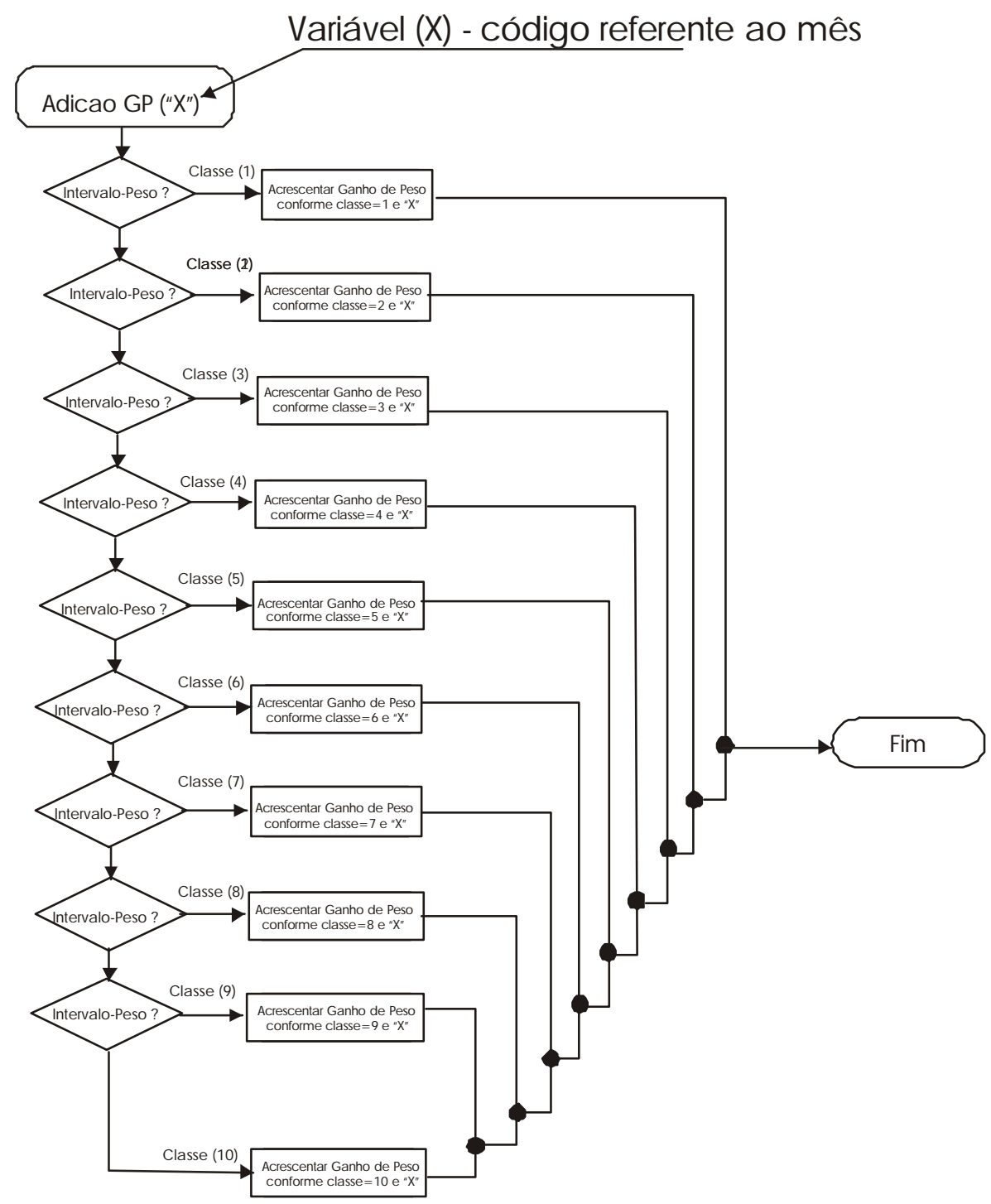

Figura 12 - Sub-rotina "Adição GPF".

\subsection{A questão do preço da terra nas análises de viabilidade econômica dos projetos}

O sistema de produção da pecuária extensiva tem como característica principal, como já é definido pelo próprio nome, o uso de grandes porções de terra. Por isso, o valor do imóvel é uma variável determinante nas expectativas da rentabilidade do tomador de decisões capitalista. 
Entretanto, a valoração de uma propriedade está ligada a fatores intrínsecos, específicos de cada uma. Quando análises são elaboradas com intuito de gerar conclusões que vão além dos limites de uma única unidade de produção, a escolha das informações que alimentam os modelos deve ser cautelosa. Tendo em vista a importância do valor da terra e a necessidade de fazer inferências sobre uma propriedade padrão, dentro de suas características regionais, foi necessário estabelecer alguns cenários para ampliar o leque de resultados e permitir o destaque daquilo que se mostrou mais relevante. Para explicitar melhor o que foi utilizado para a construção desses diferentes cenários, alguns conceitos são descritos no decorrer desse texto.

Existem três valores principais que tentam caracterizar o valor da terra no ambiente rural, o valor da terra bruta (corresponde à áreas de mata nativa), o valor da terra de pastagem (corresponde à terra que possui pasto e que muitas vezes não permite a mecanização da área) e o valor da terra de lavoura (corresponde a terra com índices de fertilidade melhores e que geralmente pode ser utilizada para cultivos mecanizados). Embora existam esses três tipos distintos de terra numa mesma região, uma área de terra pode ser transformada em outra através de mudanças promovidas por investimentos ou devido a fatores condicionados ao desenvolvimento local.

O primeiro caso pode ser exemplificado através do próprio desmatamento, o agente que compra terras brutas tem que depositar investimentos para promover o desmate, submetendo-se a condições de maior risco tanto para a sua integridade física como de sua produção, devido às adversidades encontradas em regiões afastadas dos pólos desenvolvidos. Por isso o preço desse trabalho, algumas vezes insalubre, é refletido na valorização de sua terra.

Para ilustrar o segundo caso, cita-se os exemplos de algumas regiões do interior baiano e do cerrado goiano que, mesmo sem o advento de investimentos diretos sobre a terra, elas foram indiretamente valorizadas pelo desenvolvimento local da tecnologia de irrigação e do plantio da soja em terra mista (argila-areia).

Nos dois casos, o aumento do preço da terra pode ser observado por ângulos bastante diferentes, pois o primeiro caso estaria associado ao fator de agregação de valor 
a terra e o segundo, associado ao fator especulativo dos ganhos esperados sobre a terra, em vista do desenvolvimento.

Sob essa ótica, foram definidas cinco análises que associam ou não os ganhos vinculados à agregação de valor da terra, conforme a Figura 13.

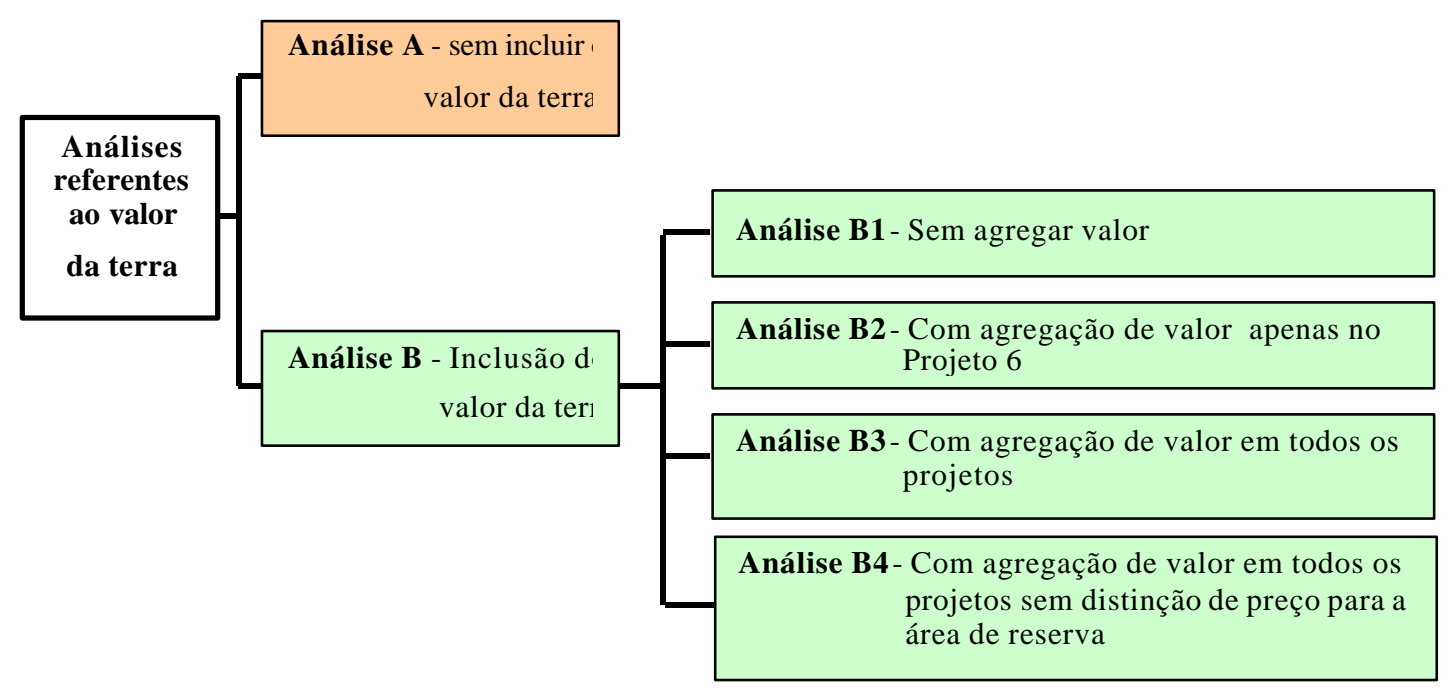

Figura 13 - Seqüência de análises relativas à precificação da terra no encerramento dos projetos.

Na primeira análise "A", optourse por retirar o valor da terra em todos os projetos, de forma a isolar os efeitos condicionados ao capital necessário para compra e do valor a ser recebido no final do período pela venda da terra.

Nas análises nomeadas pela letra "B", o valor da terra foi incluído de diferentes formas, conforme as análises "B1" a "B4". Para facilitar o entendimento do que foi proposto em cada análise é necessário lembrar que os projetos de 1 a 5 possuem inicialmente áreas com 1452 hectares, sendo 726 destinados à pastagem e 726 a reserva legal (50\%). No fim dos projetos 1 e 2 (sem alteração e herbicida com adubação), a distribuição de terras é a mesma, entretanto, nos projetos 3,4 e 5, devido às práticas agronômicas adotadas, as terras são distribuídas em 581 hectares de área agricultável 80 da área de pastagem ou $40 \%$ da área total), 145 hectares de área de pasto (onde não foi possível a mecanização) e 726 hectares (50\%) de reserva legal. 
No projeto 6 a área inicial corresponde a 2662 hectares de terra bruta e o desmatamento foi efetivado em $20 \%$ da área ( 532 hectares) ao longo dos anos.

Considerando:

$$
\begin{aligned}
& P_{T B}=\text { Preço da Terra Bruta } \\
& P_{T P}=\text { Preço da Terra Pasto } \\
& P_{T L}=\text { Preço da Terra Lavoura }
\end{aligned}
$$

- Análise "B1"- o montante gasto para a compra da terra no início do projeto é o mesmo a ser recebido no encerramento, nestes casos o preço da terra é único para a propriedade, sem distinção do preço da área de reserva. Portanto, constrói-se um cenário em que o produtor não tem expectativa de receber qualquer tipo de ganho devido às ações que possa realizar sobre a terra.

Para os projetos 1, 2, 3, 4 e 5 utilizourse:

Valor da terra no início do projeto: $P_{T B} * 600$

Valor da terra no encerramento do projeto: $P_{T B} * 600$

Para o projeto 6 utilizourse:

Valor da terra no início do projeto: $P_{T B} * 1100$

Valor da terra no encerramento do projeto: $P_{T B} * 1100$

- Análise "B2"- o montante gasto para a compra da terra no início do projeto é o mesmo a ser recebido no encerramento, apenas o projeto 6 tem distinção do valor da área de reserva. Nesse caso, o cenário difere do anterior, pois se parte da hipótese de que não existem ganhos em se alterar as áreas de pastagem, apenas os investimentos introduzidos nas áreas de terra bruta serão considerados. Essa situação pode ser real se a propriedade estiver numa região exclusiva para a pecuária e sem perspectivas do avanço da fronteira agrícola.

Para os projetos 1, 2, 3, 4 e 5 utilizourse:

Valor da terra no início do projeto: $P_{T B} * 600$

Valor da terra no encerramento do projeto: $P_{T B} * 600$

Para o projeto 6 utilizourse:

Valor da terra no início do projeto: $P_{T B} * 1100$

Valor da terra no encerramento do projeto: $P_{T B} * 880+P_{T P} * 220$ 
- Análise "B3"- em todos os projetos, os valores de encerramento agregam as ações que foram realizadas na terra, de forma proporcional, com distinção da área de reserva. $\mathrm{O}$ valor da propriedade depende diretamente da proporção dos tipos de terra que possui, por isso cada porção de terra terá um valor diferente, de forma a agregar o capital investido nas ações realizadas.

Para os projetos 1 e 2 utilizou-se:

Valor da terra no início do projeto: $P_{T B} * 300+P_{T P} * 300$

Valor da terra no encerramento do projeto: $P_{T B} * 300+P_{T P} * 300$

No fim do período, não há agregação de valor porque, no projeto 1 , o pasto não sofreu qualquer tipo de alteração, e no projeto 2 , as alterações decorrentes da aplicação de herbicidas e da adubação foram, em sua maioria, consumidas pelo aumento da taxa de lotação ao longo dos anos.

Para os projetos 3, 4 e 5 utilizourse:

Valor da terra no início do projeto: $P_{T B} * 300+P_{T P} * 300$

Valor da terra no encerramento do projeto: $P_{T B} * 300+P_{T P} * 240+P_{T L} * 60$

Nos três projetos os gastos assumidos pelo produtor para enleirar e destocar as áreas possibilitarão o uso posterior da terra pela agricultura. Ou seja, os maiores gastos assumidos pelo produtor para contratar máquinas de esteira e para comprar máquinas e implementos pesados (devido às operações de gradagem) serão recompensados pela agregação de valor a terra, que ficará situada no patamar de terra de lavoura ao fim do projeto, dado que toda a área de pasto passível de mecanização foi recuperada.

Para o projeto 6 utilizourse:

Valor da terra no início do projeto: $P_{T B} * 1100$

Valor da terra no encerramento do projeto: $P_{T B} * 880+P_{T P} * 220$

Esse projeto corresponde ao desmatamento e a explicação já foi enunciada no exemplo citado anteriormente.

- Análise "B4"- em todos os projetos, os valores de encerramento agregam as ações que foram realizadas na terra, de forma geral para a propriedade sem 
distinção da área de reserva, inclusive no projeto 6. Nesse cenário, o valor da propriedade é dado como um todo independente da proporção dos tipos de terra, valendo-se o preço do tipo de terra útil predominante. Em termos gerais, considera-se que o produtor não pode comercializar parcelas de terra de forma desagregada, ou seja, para cada hectare de terra de pasto ou lavoura, deve estar anexada a reserva legal correspondente.

Para os projetos 1 e 2 utilizou-se:

Valor da terra no início do projeto: $P_{T P} * 600$

Valor da terra no encerramento do projeto: $P_{T P} * 600$

Para os projetos 3, 4 e 5 utilizourse:

Valor da terra no início do projeto: $P_{T P} * 600$

Valor da terra no encerramento do projeto: $P_{T L} * 600$

Para o projeto 6 utilizou-se:

Valor da terra no início do projeto: $P_{T B} * 1100$

Valor da terra no encerramento do projeto: $P_{T P} * 1100$

Nas cinco análises anteriores, nota-se que não há considerações sobre opotencial especulativo do valor da terra, todos os valores finais estão vinculados apenas às condições de agregação de valor. Isso porque a questão da especulação imobiliária é muito mais complexa, e também por haver uma certa estabilização dos preços dos três tipos de terras utilizados nas análises, nos últimos anos. Através dos dados da Fundação Getúlio Vargas, o preço da terra em Rondônia não sofreu drásticas variações nos últimos seis anos conforme o Gráfico 4. 


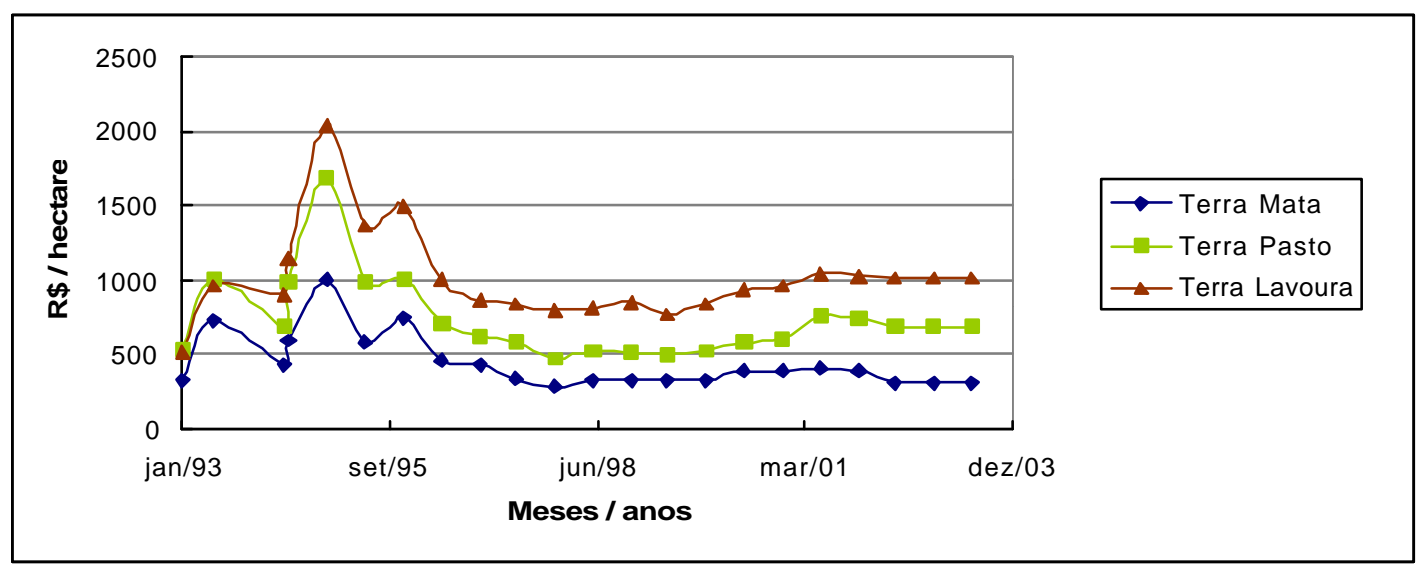

Gráfico 4 - Disposição dos preços reais da terra em RO, no último 10 anos. Fonte: FGV (2003a)

Nesse mesmo período, é possível averiguar que as linhas dos preços das terras de pasto e lavoura tiveram uma inclinação maior que as linhas dos preços das terras de mata. Várias causas podem estar associadas a essa sensível diferença e muitas outras poderão afetar a tendência dessas séries. $\mathrm{O}$ preço de terra de lavoura pode, primordialmente, depender da expansão da fronteira agrícola das microrregiões de Vilhena e Colorado do Oeste - regiões onde a agricultura já é desenvolvida (Tabela 1, pág 18) - mas esse fato está diretamente relacionado com as perspectivas futuras para o mercado interno e externo da soja, do arroz e do milho, além do progresso das vias de escoamento.

O preço da terra de pasto poderá ser influenciado futuramente pela queda de barreiras sanitárias que definem o estado de Rondônia como área de zona tampão para a febre aftosa; pelo fortalecimento da imposição da meta do "Desmatamento zero" do Governo Federal (que também influenciaria o preço da terra bruta); ou por diversos outros fatores.

Devido a esses exemplos e a noção de que existem inúmeros outros motivos que poderiam alterar, positiva ou negativamente, as taxas de ganhos especulativos, optou-se por não incluir nas análises as variações de rentabilidade decorrentes da especulação imobiliária. 


\section{RESULTADOS E DISCUSSÃO}

Os resultados foram divididos de forma seqüencial nos próximos subitens, e a discussão, em conjunto com outras análises, é apresentada a partir do subitem 4.3.

\subsection{Resultados da estimativa de evolução do rebanho}

Respeitando as limitações impostas pela capacidade de suporte das pastagens para cada sistema, foram estimados os rebanhos ao longo dos oito anos do período da análise. A demonstração desses resultados é importante, pois eles influenciaram diretamente os fluxos de caixa - devido à compra e venda dos animais - a quantidade de insumos correspondente ao tamanho do rebanho e a necessidade de contratação ou não de mão-de-obra. Por isso, os gráficos resultantes das rotinas de programação foram apresentados de forma a se ter clareza das condições às quais cada projeto foi submetido.

Em todos os casos foi determinada a venda automática dos animais que atingem o peso ideal tanto para abate como também para o comércio de bezerros. Por esse motivo, as vendas se concentraram nos meses de fevereiro a junho, sendo influenciadas pelos dados da sazonalidade do ganho de peso, conforme o Quadro 2 (página 30). As simulações visaram à obtenção máxima de uso da pastagem utilizando-se, para \$so, a compra e venda de animais. Entretanto, não se buscou maximizar a receita do produtor através de estratégias de comercialização de acordo com a sazonalidade dos preços. Essa maximização não foi assumida, pelo fato de que determinaria efeitos distintos nos fluxos de caixa que não seriam ocasionados apenas pelo acréscimo de receita gerada pelos possíveis ganhos com as técnicas de recuperação, mas também com diferenças de cunho administrativo que fogem ao escopo deste estudo. 
Nos gráficos (Gráfico 5, Gráfico 6, Gráfico 7, Gráfico 8, Gráfico 9 e Gráfico 10), as áreas correspondem à capacidade de suporte de cada projeto ${ }^{16}$, determinadas na Tabela 6 e nos quadros: Quadro 5, Quadro 6, Quadro 7, Quadro 8 e Quadro 9, respectivamente. As colunas correspondem ao total em unidades animais existentes no rebanho a cada mês.

No projeto 1 (Gráfico 5), a redução da capacidade de suporte da pastagem foi acompanhada pela taxa de descarte de matrizes superior à taxa de reposição, de forma a deprimir a quantidade de rebanho com o decorrer dos anos.

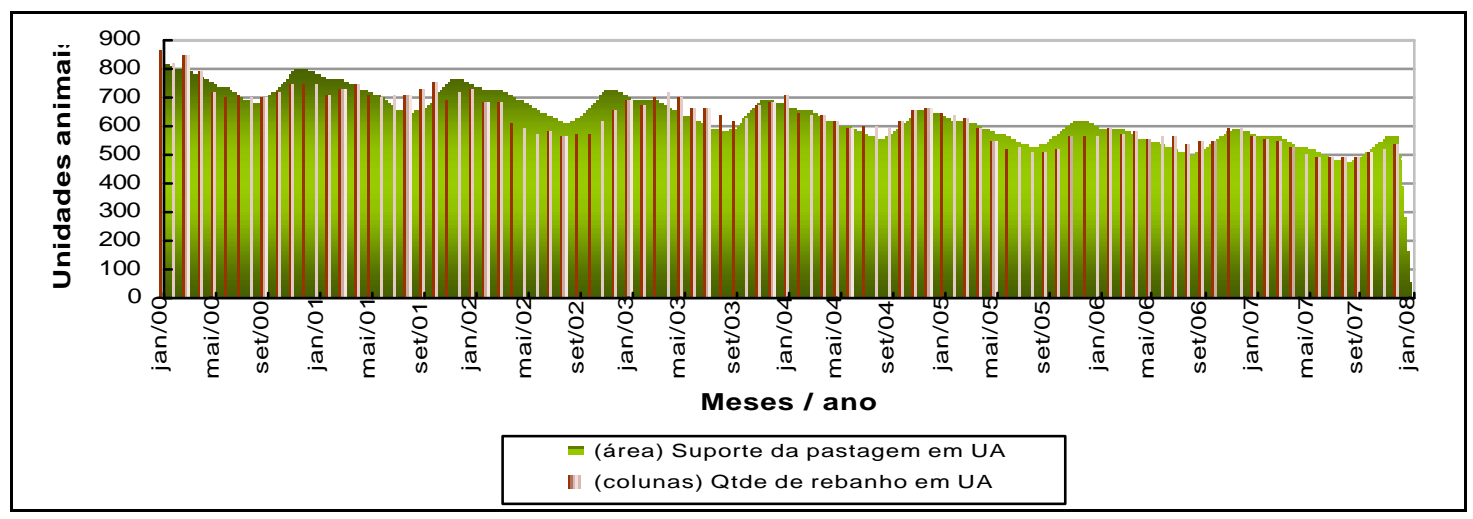

Gráfico 5 - Capacidade de suporte da pastagem e total de UA por mês - Projeto 1.

Fonte: Dados da pesquisa.

No projeto 2 Gráfico 6) as taxas de descarte de matrizes e as de reposição se mantiveram parecidas para que os níveis de UA por hectare permanecessem constantes ao longo dos anos; para o melhor aproveitamento do excedente da pastagem nos meses de verão, foi considerada a compra de animais para engorda.

\footnotetext{
${ }^{16}$ A capacidade de suporte está condicionada as médias anuais de capacidade de supo rte da propriedade e a sazonalidade das chuvas do Gráfico 3 - Distribuição sazonal das chuvas: variações e médias mensais .
} 


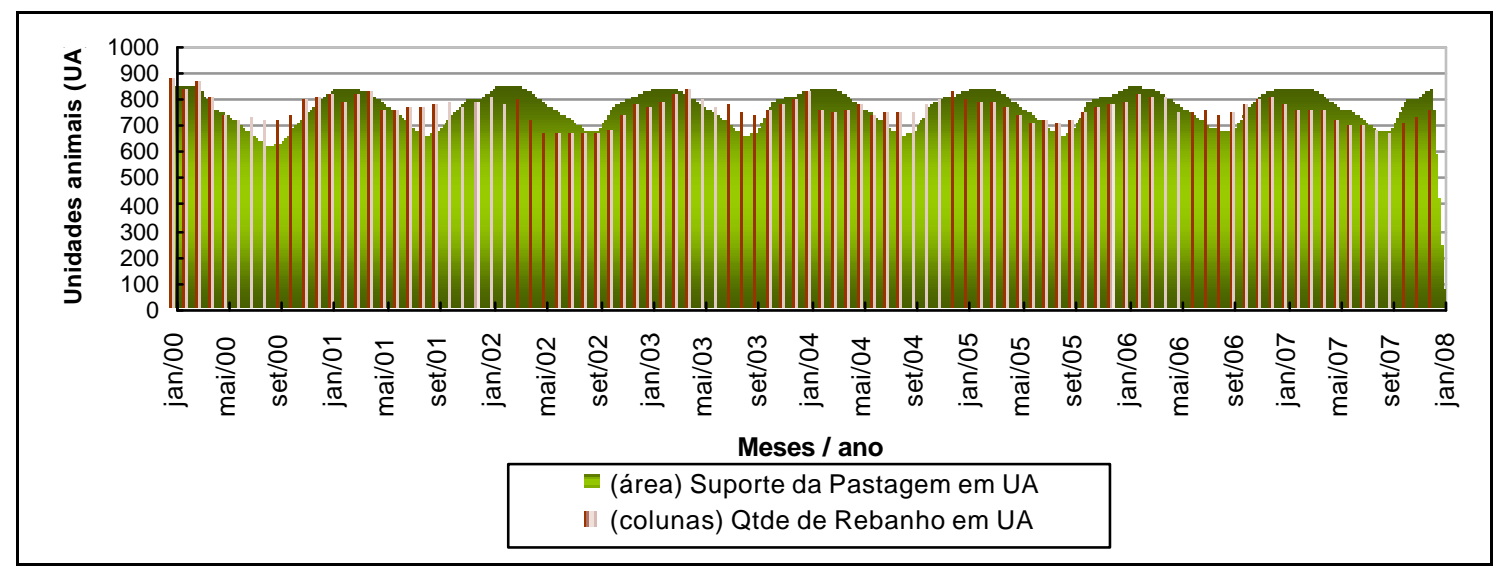

Gráfico 6 - Capacidade de suporte da pastagem e total de UA por mês - Projeto 2. Fonte: Dados da pesquisa.

No projeto 3 (Gráfico 7) a taxa de descarte de matrizes foi inferior a de reposição, elevando níveis de UA por hectare ao logo dos anos. Para o melhor aproveitamento do excedente da pastagem nos meses de verão, foi considerada a compra de animais para engorda.

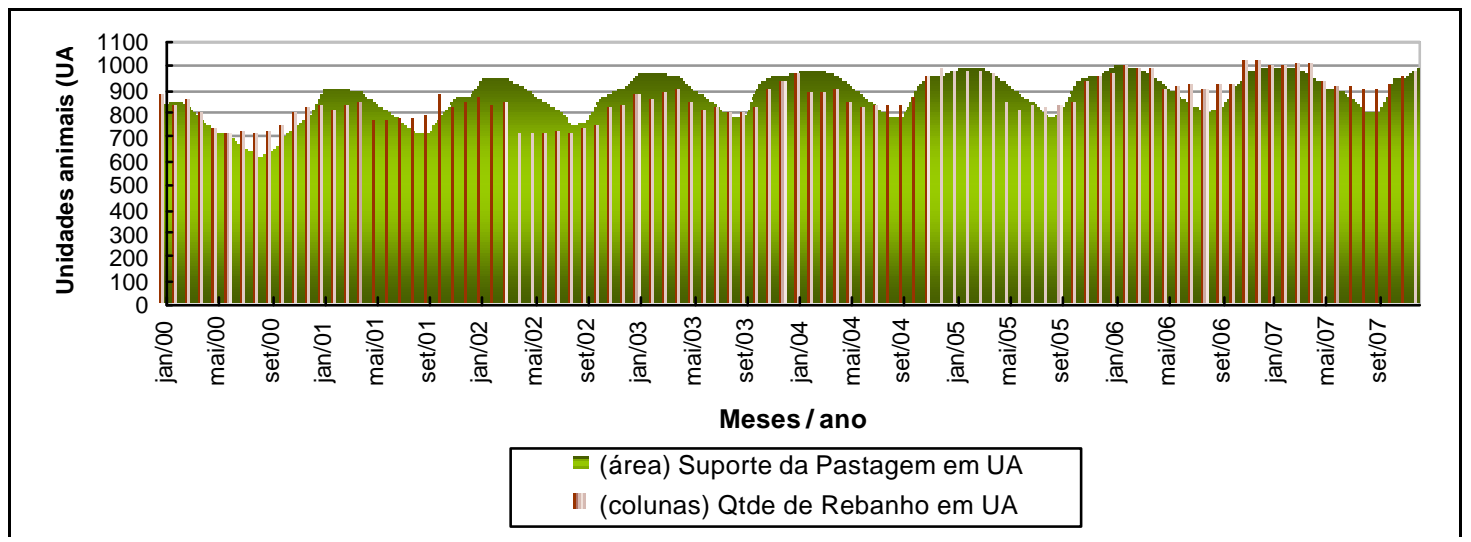

Gráfico 7 - Capacidade de suporte da pastagem e total de UA por mês - projeto 3. Fonte: Dados da pesquisa.

No projeto 4 (Gráfico 8) as medidas adotadas para manter o rebanho constante foram semelhantes àquelas adotadas no projeto 2 . 


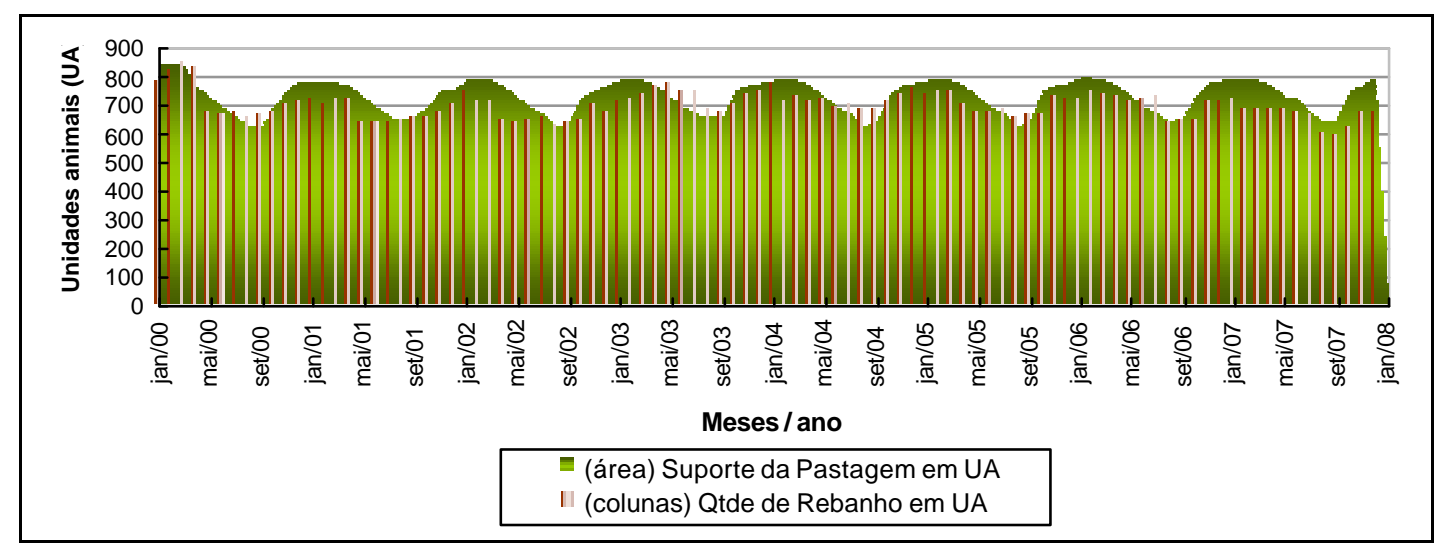

Gráfico 8 - Capacidade de suporte da pastagem e total de UA por mês - projeto 4. Fonte: Dados da pesquisa.

No projeto 5 (Gráfico 9) a recuperação indireta com o cultivo de soja aumentou a capacidade de suporte da pastagem que foi utilizada por níveis maiores do rebanho expressos em UA por hectare, sendo que a taxa de descarte de matrizes foi bastante inferior à de reposição. Para o melhor aproveitamento do excedente da pastagem nos meses de verão, também foi considerada a compra de animais para engorda.

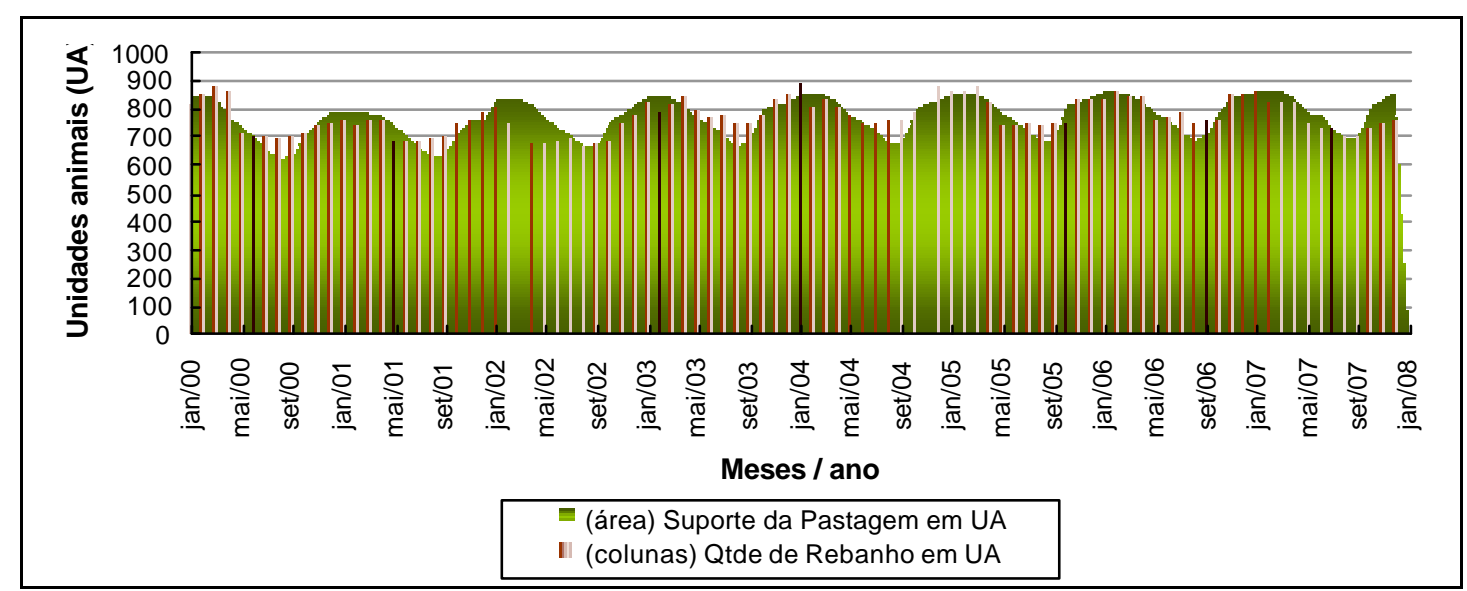

Gráfico 9 - Capacidade de suporte da pastagem e total de UA por mês - projeto 5. Fonte: Dados da pesquisa.

No caso do projeto 6 (Gráfico 10), o ano zero inexiste para efeitos da inclusão do gado na pastagem, pois a propriedade estava sendo consolidada; só a partir do ano 1 o pasto se tornou disponível. Nos anos 2 e 3, mais parcelas foram agregadas, aumentando 
a capacidade da pastagem. Porém devido à necessidade de manter todos os projetos com recursos parecidos, não foi possível obter o máximo uso da pastagem. No ano 3 - tendo em vista a restrição de capital.

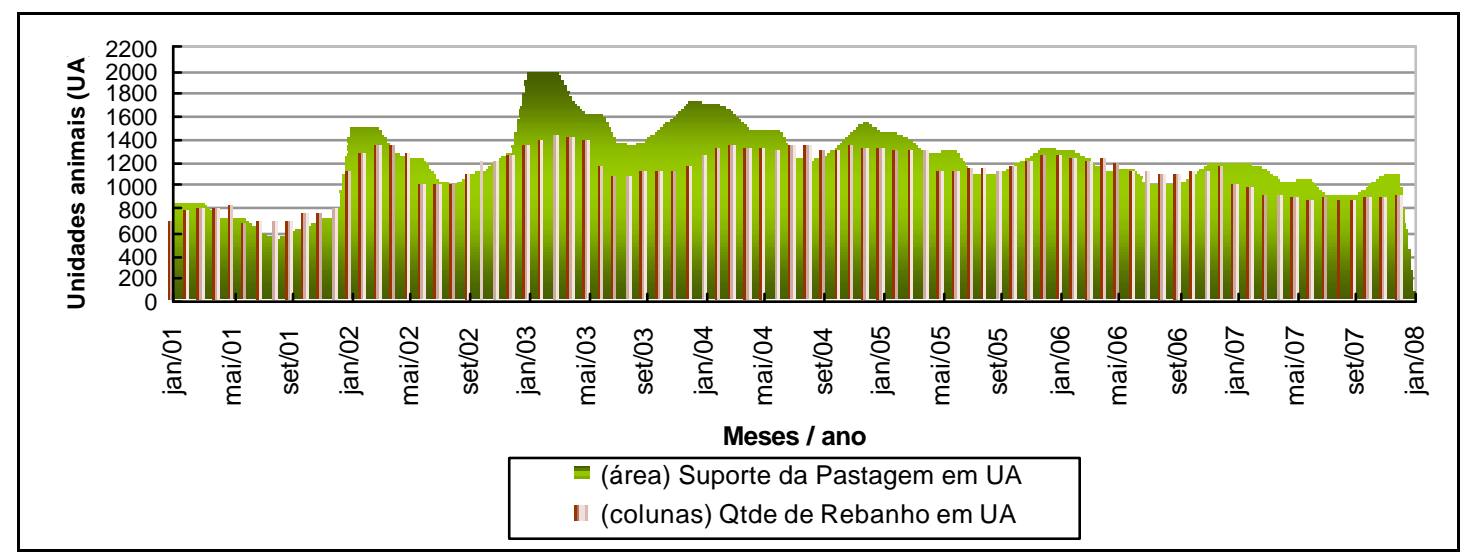

Gráfico 10 - Capacidade de suporte da pastagem e total de UA por mês - projeto 6. Fonte: Dados da pesquisa.

\subsection{Resultados das análises}

Foram estimados os fluxos de caixa através das quantidades de gado em cada mês, dos custos e receitas geradas pelos cultivos agrícolas e também pelas peculiaridades de cada projeto.

Com isso puderam ser calculados os indicadores de viabilidade econômica - VPL (Valor Presente Íquido), RBC (Relação Benefício Gusto), PBE (Período de Retorno do Capital) e TIR (Taxa Interna da Retorno) de acordo com as variações de preços decorrentes nos últimos cinco anos, conforme o Subitem 3.4.2. Para facilitar a visualização do ordenamento dos projetos, a apresentação dos resultados é feita através de gráficos de freqüência acumulada para as análises que envolvem a TIR (Gráfico 11, Gráfico 13, Gráfico 15, Gráfico 17 e Gráfico 19) e também da RBC (Gráfico 12, Gráfico 14, Gráfico 16, Gráfico 18 e Gráfico 20), respeitando o que foi mencionado no Subitem 3.5 para valores de terra distintos. 


\subsubsection{Resultados - análise A}

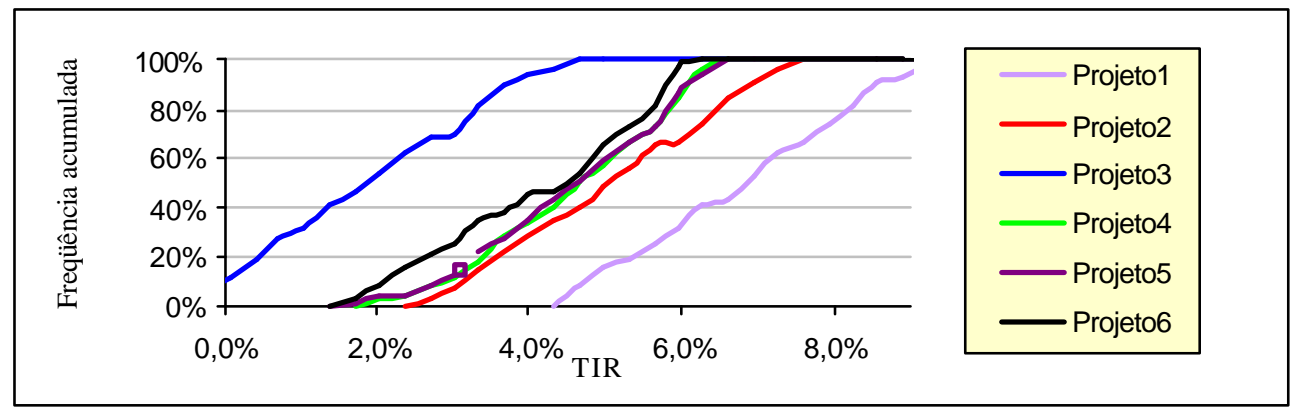

Gráfico 11 - TIR resultante - análise A (sem o valor da terra).

Fonte: Dados da pesquisa.

Isolando-se a questão da terra, as melhores taxas foram obtidas com a propriedade sem alterações, ou seja, a propriedade que não incluir nenhum pacote tecnológico se torna a mais viável, para as situações locais. O projeto 3 - gradagem e adubação - é o menos viável e pode, também, apresentar o risco de prejuízo. Em relação aos riscos ${ }^{17}$, que seriam notados nesse tipo de gráfico através da conformação das linhas, não há diferenças muito significativas entre os projetos. Além disso, como as linhas não se cruzam, o ordenamento dos projetos não gera dúvidas. O perfeito ordenamento dos projetos, tendo em vista o fato de que as linhas não se cruzam, está relacionado ao conceito da dominância estocástica de primeira ordem.

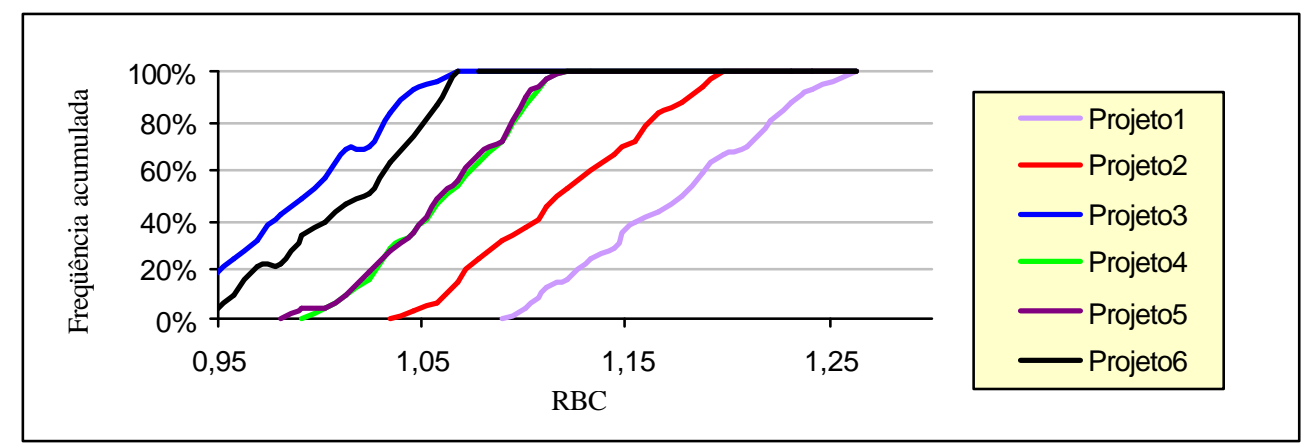

Gráfico 12 - RBC resultante - análise A(sem o valor da terra).

Fonte: Dados da pesquisa.

\footnotetext{
17 A inclinação das linhas expressa o grau de risco ao qual estão submetidos os projetos de acordo com as TIRs e as RBCs. Linhas mais inclinadas em relação ao eixo horizontal advêm de distribuições com menores variâncias, que por sua vez, caracterizam-se por assumirem menores riscos associados aos desvios dos valores esperados. De forma inversa, as linhas mais paralelas ao eixo horizontal denotam distribuições com maiores desvios e com maiores riscos.
} 
Além de ter taxas melhores, a relação benefício-custo também é mais favorável no projeto 1 e, no caso dos projetos 3, projetos 4 e 5 (sobrepostos) e do projeto 6, a ordem não é alterada, mas há um maior distanciamento entre as linhas de freqüência acumulada. Isso decorre do fato de que a todos os projetos foi dado um limite de capital disponível de cerca de $10 \%$ do valor do patrimônio. Entretanto, cada projeto utilizou proporções diferentes desse capital. Por esse motivo e também pela diferença das receitas geradas, as linhas de RBC ficaram mais distantes, entre si.

Embora essas análises da TIR e RBC sejam importantes para classificar os projetos sem a interferência do valor da terra, as taxas de retorno podem não refletir a realidade das margens de rentabilidade, pois a influência da terra na atividade pecuária é bastante alta devido aos grandes montantes envolvidos.

\subsubsection{Resultados - análise B1}

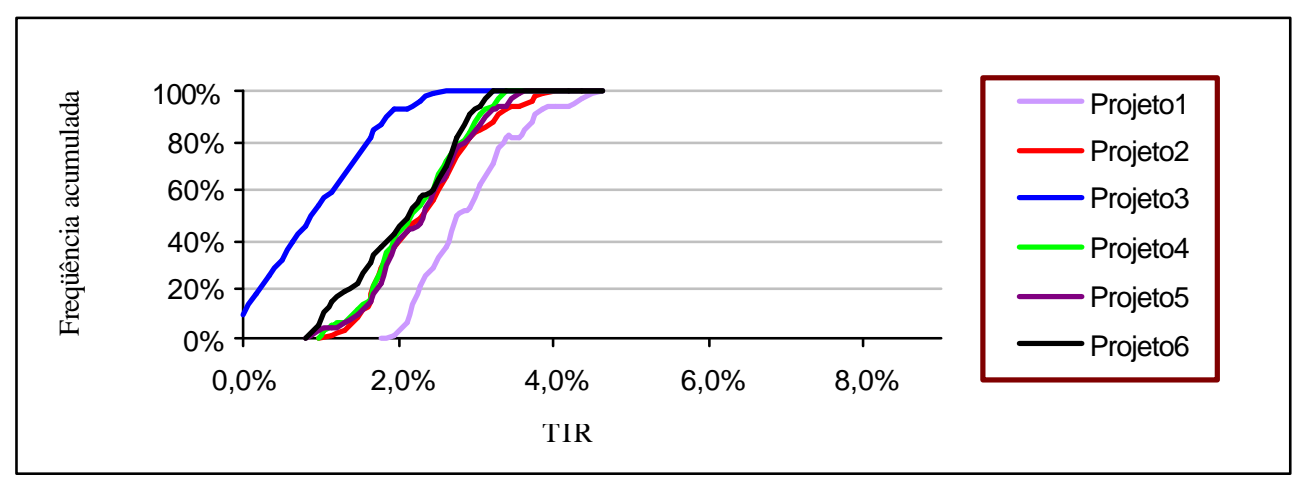

Gráfico 13 - TIR resultante - análise B1 (com o valor da terra, mas sem agregar valores).

Fonte: Dados da pesquisa.

Quando a terra passa a ser incluída nas análises, as taxas de retorno obviamente são alteradas. Quando não se consideram que os investimentos depositados na pastagem venham a ser somados nos valores patrimoniais, e que a opção do desmatamento também não acre scente nenhum valor na terra, então, o ordenamento dos projetos não é alterado, mas todas as taxas de retorno são reduzidas. 


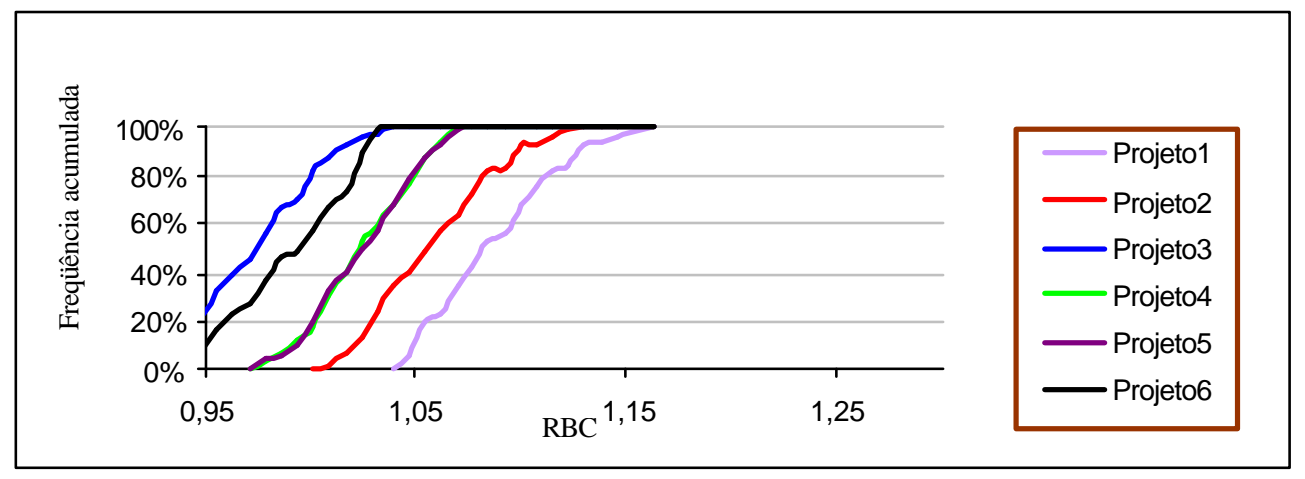

Gráfico 14 - RBC resultante - análise B1 (com o valor da terra, mas sem agregar valores).

Fonte: Dados da pesquisa.

As mesmas considerações feitas para o Gráfico 13 podem ser feitas para a análise benefício custo.

\subsubsection{Resultados - análise B2}

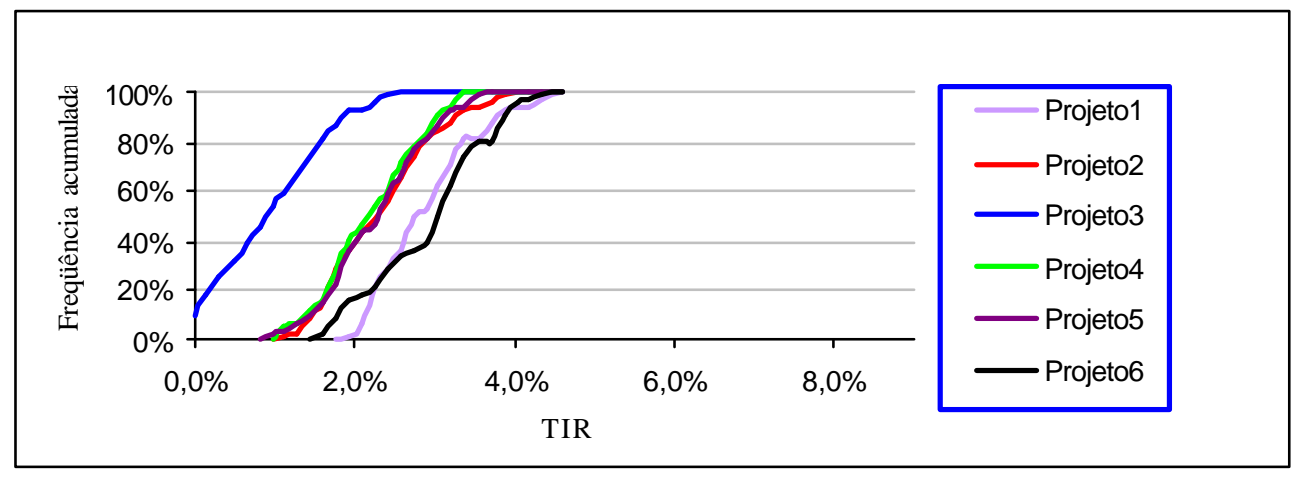

Gráfico 15 - TIR resultante - análise B2 (com o valor da terra, agregando valor apenas ao projeto 6 - desmatamento).

Fonte: Dados da pesquisa.

Em alguns locais em que as fronteiras de expansão agrícola estejam distantes ou as formas de escoamento e os mercados regionais inviabilizem os cultivos agrícolas de grãos, é possível aceitar as colocações de que o preço da terra no encerramento do projeto não possa cobrir o montante de investimentos depositados. Entretanto, é bastante improvável que a terra de mata nativa (cuja exploração madeireira já tenha sido realizada), depois de ser transformada em pasto, continue com o mesmo valor. Por isso, ao agregar valor apenas à porção de terra desmatada no projeto 6 (20\% da área), 
passando do valor de terra bruta para terra pasto, o ordenamento dos projetos é alterado. As opções, entre desmatar e ficar como está, são as mais viáveis.

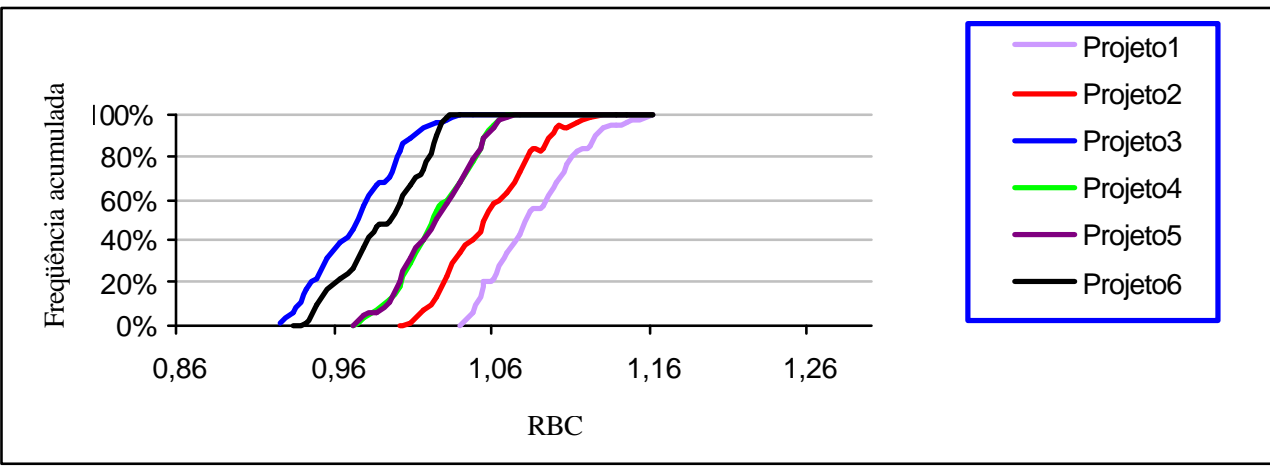

Gráfico 16 - RBC resultante - análise B2 (com o valor da terra, agregando valor apenas ao projeto 6 - desmatamento).

Fonte: Dados da pesquisa.

A conclusão anterior será útil se o produtor estiver disposto a investir todo o montante do capital disponível (10\% do patrimônio total) na nova propriedade, haja vista que a RBC é inferior, ou seja, é preciso investir mais no projeto 6 para se ter a mesma rentabilidade do projeto 1 .

\subsubsection{Resultados - análise B3}

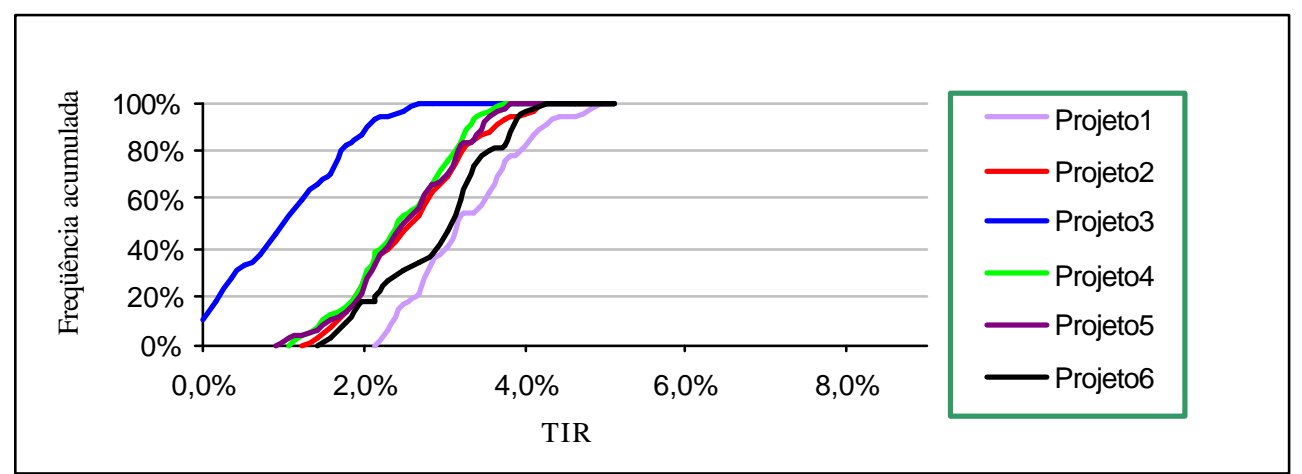

Gráfico 17 - TIR resultante - análise B3 (agregando proporcionalmente o valor a todos os projetos).

Fonte: Dados da pesquisa. 
Nesse caso, considera-se que o valor da terra (ao término do projeto) agregará proporcionalmente os investimentos efetuados sobre a terra no decorrer dos anos de cada projeto. As linhas dos projetos praticamente não são alteradas em vista da situação anterior, apenas a linha do desmatamento fica agora totalmente atrás da linha do projeto 1 , mas à frente dos outros.

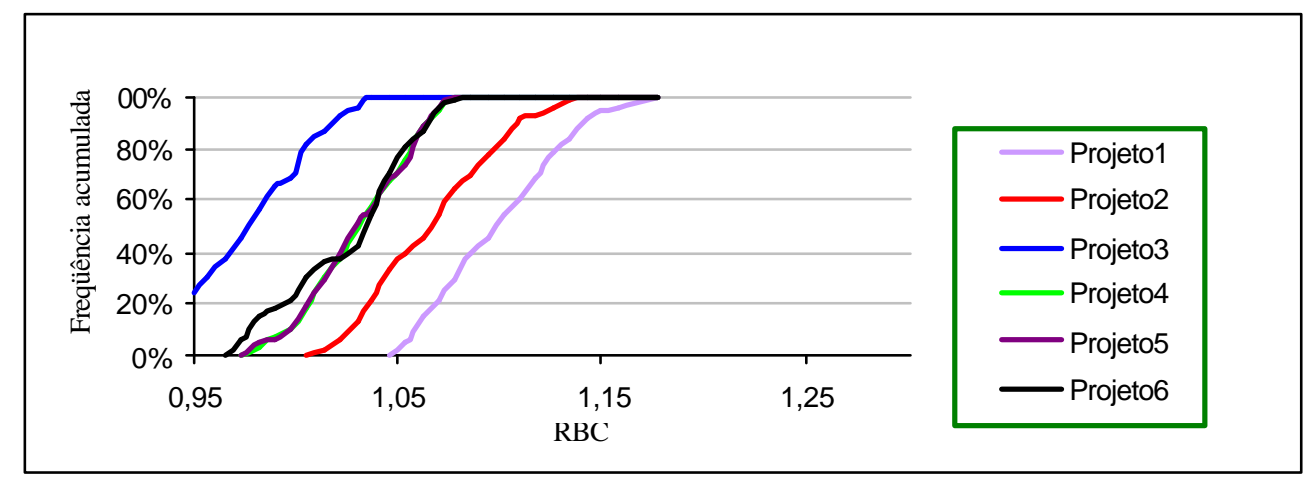

Gráfico 18 - RBC resultante - análise B3 (agregando proporcionalmente o valor a

Fonte: Dados da pesquisa. todos os projetos).

Quanto à análise da RBC, não há alterações em relação à análise anterior. Embora esta análise pareça ser bastante sensata, passa a ser considerado que o valor da área de reserva é separado do valor das terras utilizadas pela pecuária, ou seja, seria possível vender o pasto e a reserva separadamente, e siso, perante a legislação em vigor, não é permitido.

\subsubsection{Resultados - análise B4}

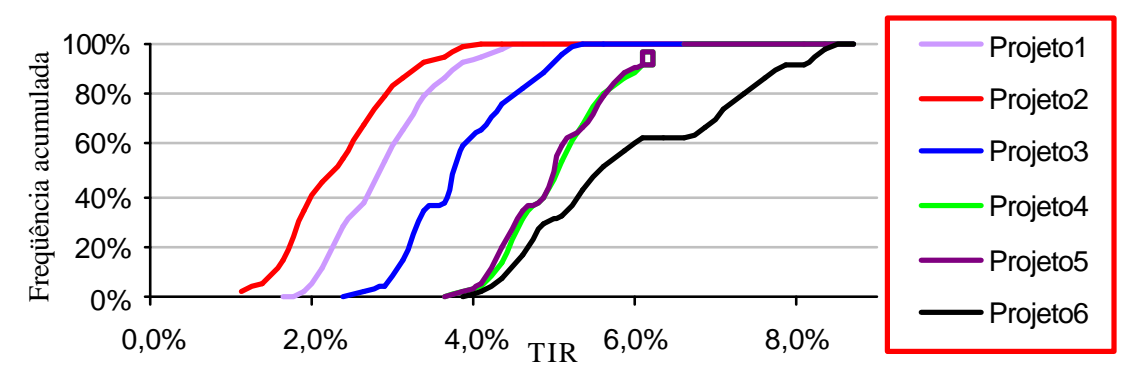

Gráfico 19 - TIR resultante - análise B4 (agregando o valor a todos os projetos). Fonte: Dados da pesquisa. 
Embora a hipótese de que todo o valor da terra dependa da atividade empregada na maior porção de área útil pareça ser bastante forte, ela deve ser considerada, pois em muitos locais, o preço da terra já está condicionado à área averbada de reserva, ou seja, quando uma propriedade é comprada, o preço da terra estipulado também abrange a área de reserva, não sendo permitida a separação, pois a área útil está vinculada legalmente à área de reserva. Por isso, os projetos 3, 4 e 5 assumiram, em sua totalidade, ser propriedades de terras de hvoura e o projeto 6 ser uma propriedade de terra de pasto. Fica controversa a comparação entre os projetos 1 e 2, que têm $50 \%$ de suas áreas com mata (o que lhes era permitido na legislação anterior), com a propriedade 6 que possui $80 \%$ de reserva (máximo de uso permitido atualmente), ambas as terras possuem o mesmo preço por hectare.

Nesse caso, a linha da frequiência acumulada do projeto 6 é totalmente deslocada para a direita, tornando este projeto o mais rentável e os projetos 3, 4 e 5, agora, ultrapassam a situação original do projeto 1 , sendo os projetos 4 e 5 os mais viáveis, pois os custos são abatidos pela renda das culturas.

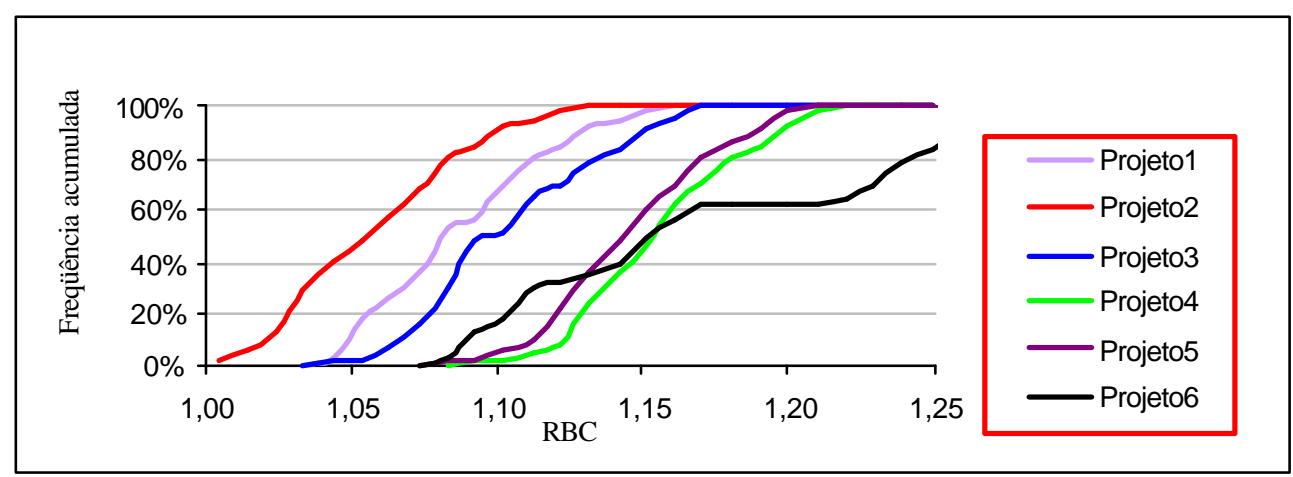

Gráfico 20 - RBC resultante - análise B4 (agregando o valor a todos os projetos). Fonte: Dados da pesquisa.

Entretanto, quando a relação benefício custo é avaliada, o projeto do arroz se diferencia do da soja devido aos menores austos de implantação do cultivo. Afixação de nitrogênio pela soja induz a resultados de igual eficiência, mas os custos de implantação 20 a 30\% maiores que os do arroz tornam a recuperação com o arroz mais eficiente. Quando comparado com o desmatamento, mesmo que os investimentos iniciais sejam 
equivalentes (até cerca de $10 \%$ do patrimônio), a compra de animais para povoar as novas áreas desmatadas torna o projeto 6 menos atrativo. Devido à interseção das linhas entre os projetos 4 e 5 com o projeto 6 , os projetos 4 e 5 possuem uma margem de risco da RBC inferior ao desmatamento, dadas as inclinações das linhas serem mais acentuadas. Entretanto, o projeto 6 ainda é mais vantajoso, pois os interceptos das três linhas praticamente saem do mesmo ponto. Visualizando os gráficos das frequiências discretas da RBC (Gráfico 21, Gráfico 22 e Gráfico 23) isoladamente, é possível cons tatar melhor essa afirmação.

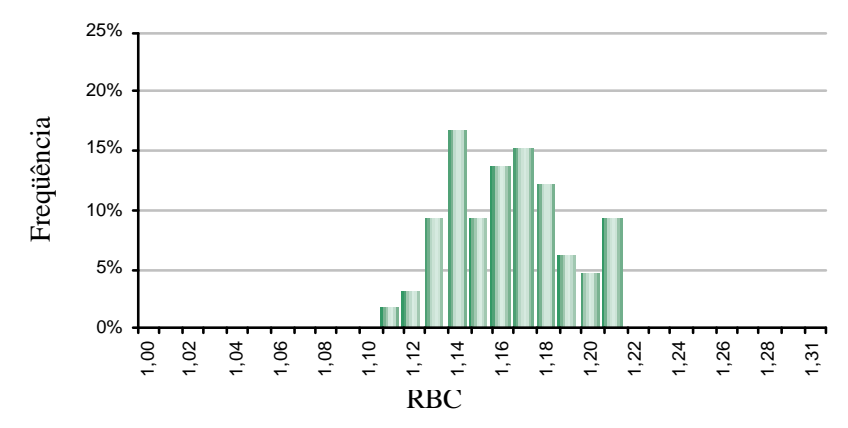

Gráfico 21 - projeto 4 - distribuição dos valores da RBC.

Fonte: Dados da pesquisa.

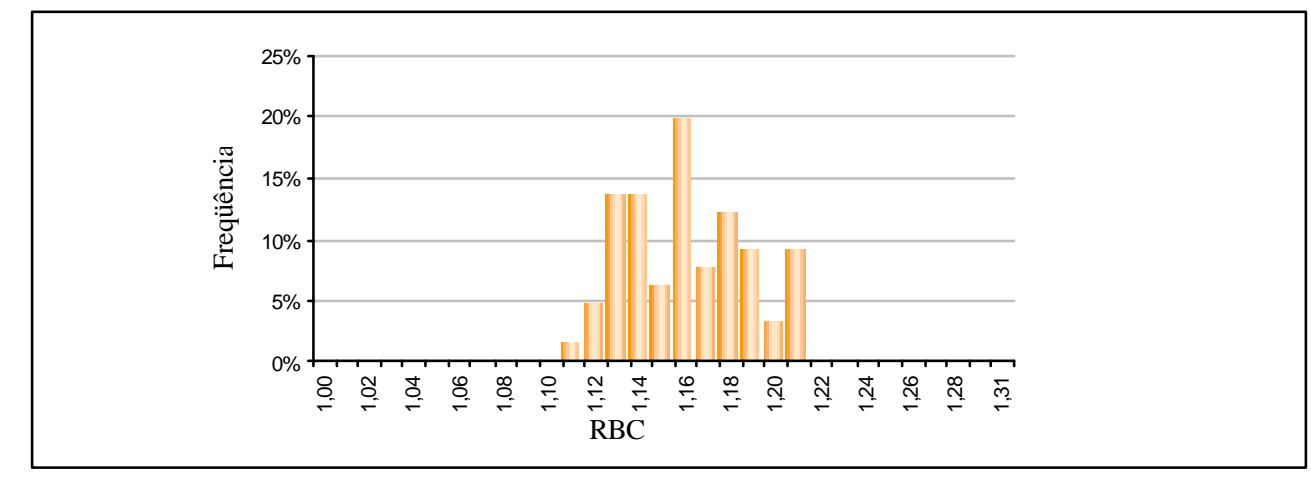

Gráfico 22 - projeto 5 - distribuição dos valores da RBC.

Fonte: Dados da pesquisa. 


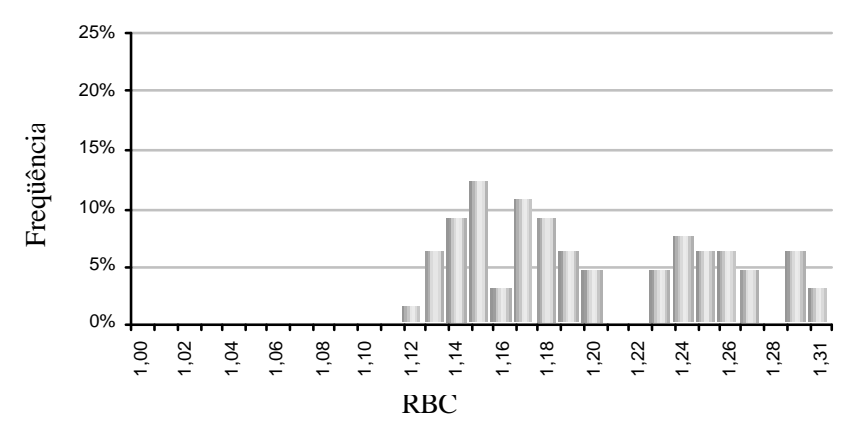

Gráfico 23 - projeto 6 - distribuição dos valores da RBC.

Fonte: Dados da pesquisa.

Frente aos resultados dessa última análise, notam-se vantagens bastante importantes para o projeto que considera o desmatamento (Gráfico 19). Os projetos $4 \mathrm{e}$ 5, relacionados às técnicas de recuperação indireta, têm TIRs e riscos semelhantes, tornando-se indiferentes ao processo de tomada de decisão, e chegam a proporcionar rendimentos duas vezes superiores aos encontrados no projeto sem alteração (projeto 1). O projeto 2 (herbicida e adubação), acaba por se tornar o pior, nessa análise.

Em todas as análises, o VPL não foi citado, visto que a visualização gráfica de todos os projetos em uma única figura ficaria bastante dificultada e os resultados, que seriam de interesse para comparação dos valores de VPL, estariam mais atrelados æ̀ simulações com diferentes taxas de juros. Isso porque poderia haver diferenças na classificação dos projetos sob taxas de juros diferentes, mas, em todos os casos, as análises desse tipo foram realizadas e os resultados não tiveram influência nas ordenações descritas, anteriormente, para a RBC e a TIR. A Tabela 13 ilustra como exemplo a análise B4 e os valores de VPL para os juros anuais variando os limites de 0 a $8 \%$. 
Tabela 13. Resultados - VPL, para a última observação da análise B4.

\begin{tabular}{rrrrrrr}
\hline Taxas & \multicolumn{1}{c}{ projeto1 } & \multicolumn{1}{c}{ projeto2 } & \multicolumn{1}{c}{ projeto3 } & \multicolumn{1}{c}{ Projeto4 } & \multicolumn{1}{c}{ projeto5 } & \multicolumn{1}{c}{ projeto6 } \\
\hline $0,00 \%$ & $\mathrm{R} \$ 261.101$ & $\mathrm{R} \$ 177.324$ & $\mathrm{R} \$ 459.602$ & $\mathrm{R} \$ 643.351$ & $\mathrm{R} \$ 653.090$ & $\mathrm{R} \$ 1.221 .633$ \\
$1,33 \%$ & $\mathrm{R} \$ 83.691$ & $-\mathrm{R} \$ 4.479$ & $\mathrm{R} \$ 229.354$ & $\mathrm{R} \$ 407.694$ & $\mathrm{R} \$ 409.489$ & $\mathrm{R} \$ 936.571$ \\
$2,67 \%$ & $-\mathrm{R} \$ 74.941$ & $-\mathrm{R} \$ 166.642$ & $\mathrm{R} \$ 24.788$ & $\mathrm{R} \$ 197.570$ & $\mathrm{R} \$ 192.346$ & $\mathrm{R} \$ 683.697$ \\
$4,00 \%$ & $-\mathrm{R} \$ 217.025$ & $-\mathrm{R} \$ 311.521$ & $-\mathrm{R} \$ 157.228$ & $\mathrm{R} \$ 9.916$ & $-\mathrm{R} \$ 1.513$ & $\mathrm{R} \$ 459.117$ \\
$5,33 \%$ & $-\mathrm{R} \$ 344.502$ & $-\mathrm{R} \$ 441.165$ & $-\mathrm{R} \$ 319.411$ & $-\mathrm{R} \$ 157.929$ & $-\mathrm{R} \$ 174.849$ & $\mathrm{R} \$ 259.446$ \\
$6,67 \%$ & $-\mathrm{R} \$ 459.061$ & $-\mathrm{R} \$ 557.356$ & $-\mathrm{R} \$ 464.122$ & $-\mathrm{R} \$ 308.282$ & $-\mathrm{R} \$ 330.064$ & $\mathrm{R} \$ 81.737$ \\
$8,00 \%$ & $-\mathrm{R} \$ 562.179$ & $-\mathrm{R} \$ 661.648$ & $-\mathrm{R} \$ 593.418$ & $-\mathrm{R} \$ 443.164$ & $-\mathrm{R} \$ 469.254$ & $-\mathrm{R} \$ 76.577$ \\
\hline
\end{tabular}

Fonte: Dados da pesquisa.

É possível notar que a ordem dos projetos não foi alterada, sob os diferentes níveis de taxas de juros anuais.

No caso do PBE (Tabela 14), nenhum projeto, nenhuma análise, sob diferentes taxas de retorno positivas, foi capaz de remunerar o capital investido da fase inicial, a não ser quando toda a propriedade é liquidada no último mês dos oito anos estimados como o horizonte de todos os projetos (nonagésimo quinto mês após o primeiro mês do ano zero). Isso é esperado nas situações em que as grandes somas patrimoniais são incluídas nas análises. Mesmo no caso em que a terra não foi incluída - Análise $\mathrm{A}$-, os valores patrimoniais de construções, máquinas, implementos e, principalmente, do rebanho são muito altos para serem abatidos apenas pelo saldo do fluxo de caixa.

Tabela 14. Resultados - PBE, para a última observação a da análise B4.

\begin{tabular}{rrrrrrr}
\hline & projeto1 & projeto2 & projeto3 & projeto4 & projeto5 & projeto6 \\
$0,00 \%$ & 95 & 95 & 95 & 95 & 95 & 95 \\
$1,33 \%$ & 95 & Inviável & 95 & 95 & 95 & 95 \\
$2,67 \%$ & Inviável & Inviável & 95 & 95 & 95 & 95 \\
$4,00 \%$ & Inviável & Inviável & Inviável & 95 & Inviável & 95 \\
$5,33 \%$ & Inviável & Inviável & Inviável & Inviável & Inviável & 95 \\
$6,67 \%$ & Inviável & Inviável & Inviável & Inviável & Inviável & 95 \\
$8,00 \%$ & Inviável & Inviável & Inviável & Inviável & Inviável & Inviável \\
\hline
\end{tabular}

Fonte: Dados da pesquisa.

Devido ao fato de que a ariação das taxas de juros não foi capaz de influir no ordenamento dos projetos, como foi mostrado ios exemplos do VPL e PBE, foi definida uma taxa única de juros da ordem de $1 \%$ a.a. para os cálculos da RBC em todas as análises anteriores. A escolha dessa reduzida taxa foi influenciada pelos baixos níveis de 
rentabilidade observados na maioria das simulações. Por isso, optou-se por uma taxa mínima de $1 \%$ a.a. para considerar ação temporal incidente nos projetos e permitir a presença da maior parte dos resultados nos quadrantes positivos dos gráficos.

\subsection{Discussão e realização de novas análises}

Tendo em vista todos os resultados descritos, constata-se que, de forma geral, o projeto 1 (sem alterações) é superior (apenas na análise B4 o projeto 1 é desfavorecido). Em quase todas as análises, o projeto 6 (desmatamento), em termos da rentabilidade medida pela TIR, é equivalente ou superior às diferentes formas de recuperação da pastagem. Nos casos em que o valor da terra bruta é agregado após o desmatamento, o projeto 6 fica próximo ou se torna mais rentável que o projeto 1. Quanto aos projetos que utilizam as formas indiretas de recuperação (soja e arroz), praticamente não houve grandes diferenças tanto de rentabilidade como de risco. Frente a essas observações, outros tópicos foram elaborados no sentido de discutir os resultados dessa pesquisa e, quando necessário, prover novas análises para se ter um melhor esclarecimento.

\subsubsection{O uso do IGP-DI para deflacionar as séries de preços}

O Índice Geral de Preços - Disponibilidade Interna - IGP-DI é calculado através da média aritmética ponderada de outros três índices obtidos mensalmente pela Fundação Getúlio Vargas. A variação do Índice de Preços no Atacado - IPA detém a maior influência no valor do IGP - DI, pois atua com $60 \%$ da média ponderada, os outros índices (Índice de Preços ao Consumidor - IPC e Índice Nacional da Construção Civil - INCC) influem com 30\% e 10\%, respectivamente. A composição dos produtos no atacado que formam o IPA é bastante sensível à variação das taxas cambiais especialmente ao dólar. Devido a esse fator e ao grande peso que o IPA exerce na formação do IGP-DI, a utilização desse índice como agente para deflacionar séries históricas é bastante pertinente quando os produtos e fatores têm maior relação com as taxas de câmbio.

Os preços de alguns insumos e produtos que assumem grande importância nas simulações desse estudo, como o sal mineral, os adubos e a soja, estão relacionados 
diretamente com o dólar. Entretanto, outros itens, como mão-de-obra e o próprio preço da arroba bovina são regidos pelo mercado interno e, por isso, o uso do IGP-DI deixa de ser o mais apropriado.

Com o intuito de reduzir esse viés, as simulações foram novamente processadas, tendo como única diferença, o uso de outro índice de mensuração dos efeitos da inflação. Para tanto, o Índice de Preços ao Consumidor Amplo (IPCA), calculado pelo IBGE, foi escolhido por representar melhor a cesta de consumo do mercado interno.

Os resultados provenientes das duas simulações (IGP-DI e IPCA) foram comparados em todas as análises e são apresentados no Anexo D.

Os valores dos indicadores de viabilidade econômica se apresentaram de forma diferente para os dois índices, sendo significativamente inferiores para o IPCA. Além disso, nas análises que utilizam o IPCA, os níveis de rentabilidade dados pela TIR ficaram pouco distantes, criando, em alguns casos, uma maior indiferença frente à escolha dos projetos. Mas, em linhas gerais, o ordenamento dos projetos preferíveis (projeto 1 e 6) não foi alterado quando os gráficos da TIR são analisados; apenas o distanciamento entre os projetos 1, 2, 4, 5 e 6, com o uso do IPCA, ficou menor.

As maiores diferenças observadas no ordenamento dos projetos foram encontradas 10s resultados da análise B4, sendo que os projetos 1 e 2 ficaram próximos aos projetos 4 e 5 , reforçando a hipótese de que o projeto 1 (sem alterações) tende a ser preferível aos que utilizam as práticas de recuperação.

\subsubsection{A taxa de lotação e a viabilidade econômica do projeto 1 (sem alterações)}

Na propriedade padrão, definida através de dados obtidos por meio de painéis no estado de Rondônia, foi considerada a taxa de lotação de 1,05 UA/ha. Esse número foi usado como base para simulação do rebanho, sendo que, a cada ano, a taxa foi reduzida em $5 \%$, no projeto sem alteração, chegando àtaxa de 0,73 UA/ha no último ano.

Esse pode ser o primeiro fator determinante para o sucesso do projeto 1 , ou seja, se os níveis atuais de suporte da pastagem realmente estiverem situados em torno de 1,0 UA/ha, os sistemas de recuperação da pastagem, propostos neste trabalho, não serão mais eficientes do que o sistema convencional de uso do solo. Empiricamente, não foi 
diagnosticado como hábito comum o uso das práticas de recuperação da pastagem no estado de Rondônia, ao contrário do que foi observado nos estados do Mato Grosso do Sul e em Goiás. Entretanto, Rondônia é caracterizada por possuir diversos tipos de solo, e também pelo fato de existirem áreas que foram desmatadas há mais de três décadas. Por isso uma parcela das propriedades rurais deve apresentar taxas de lotação inferiores a 1,0 UA/ha. Com o intuito de minimizar a dúvida sobre a influência da taxa de lotação no processo decisório relacionado à questão do uso ou não das práticas de recuperação, uma outra simulação foi realizada nos mesmos moldes da análise A (sem a inclusão do valor da terra), porém com a taxa de lotação iniciada em 0,73 UA/ha, como se o produtor tomasse novamente a decisão entre os mesmos projetos após o oitavo ano.

Através dos gráficos (Gráfico 24 e Gráfico 25) é fácil observar que os projetos de usam as técnicas de recuperação (exceção feita ao projeto 3) são superiores tanto para a TIR como para a RBC, sendo mais favoráveis ao projeto 2 , pois ĩo é considerada a agregação de valor dada para a terra. 


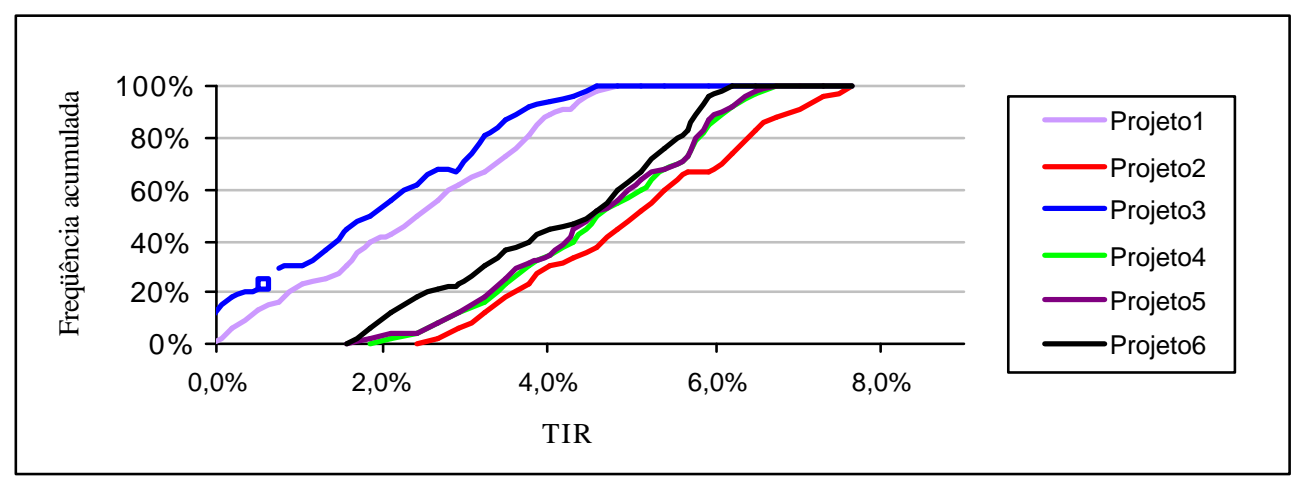

Gráfico 24 - TIR - Análise A - Utilizando 0,73 UA/ha no projeto 1.

Fonte: Dados da pesquisa.

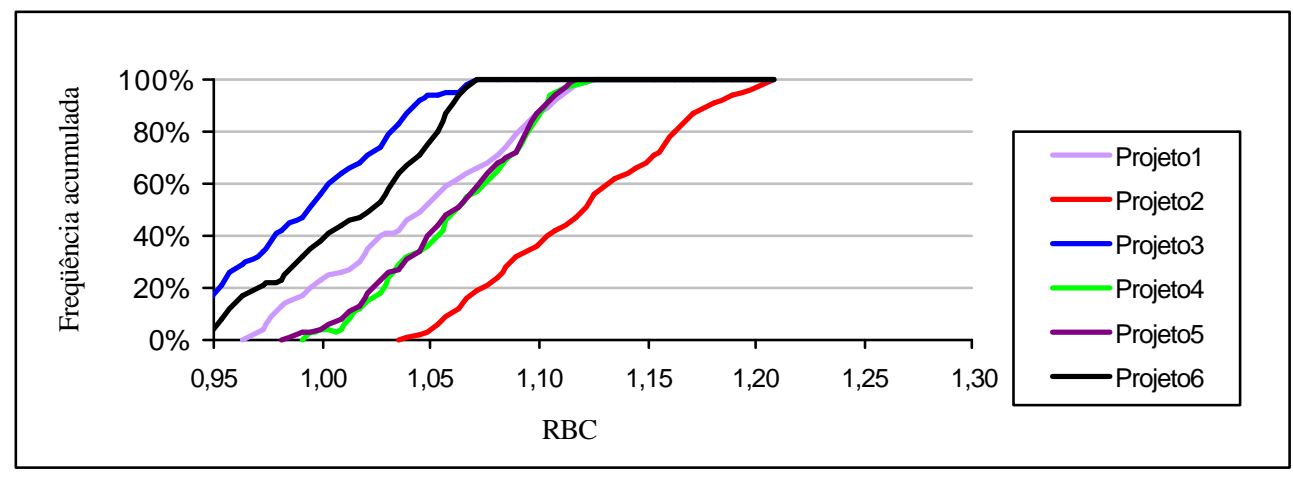

Gráfico 25 - RBC - Análise A - Utilizando 0,73 UA/ha no projeto 1.

Fonte: Dados da pesquisa.

Outra característica importante está associada com a forma de administração da propriedade. Nos projetos voltados à recuperação da pastagem, não foram consideradas as alternativas que o produtor teria para utilizar as variações sazonais de preços a seu favor. Muitas vezes, em outras regiões do país, as pastagens são recuperadas com o objetivo, não de aumentar a capacidade de suporte geral da pastagem, mas sim, para se obter um excedente de pasto nos meses de seca, propiciando ganhos com a venda de animais na entressafra. Isso não foi colocado nesses projetos, pois isso alteraria o direcionamento do estudo. Sistemas de rotação de pastos através da vedação de alguns piquetes para reservar a forragem para o período seco, ou seja, mudanças gerenciais apenas de manejo, poderiam ser efetivadas sem qualquer necessidade de recuperar a 
pastagem. Isso significa que as opções de gerenciamento podem ser encaradas também como outros projetos.

É necessário observar que o período de estiagem no estado de Rondônia é menor do que em muitas regiões importantes para a pecuária de corte brasileira. Por isso, os possíveis ganhos com a sazonalidade podem não ser tão expressivos.

Outro importante fator que pode impedir os ganhos com as variações no preço da arroba e dos animais, ao longo do ano, volta-se à existência da Instrução Normativa $n^{\circ} 6$, de 13/07/2000 (Brasil, 2000), que classifica como áreas de controle da febre aftosa o estado de Rondônia e o sul do Pará. Nessas áreas, que são classificadas como zonas tampão (zonas de médio risco), a venda de animais vivos e de carcaças inteiras é permitida apenas para os estados das regiões Norte e do Nordeste do país (com exceção da Bahia). Para os estados da zona livre de vacinação, a carne pode apenas ser comercializada se desossada. Tal fato impede que os produtores do Norte e Nordeste possam obter vantagens com a comercialização de animais vivos, especialmente, com a venda de bezerros para engorda. Essa característica é um fitor bastante importante por restringir as opções de compra e venda de animais a serem utilizados nos períodos de entressafra.

\subsubsection{A diferença dos riscos associados aos projetos}

Neste estudo, os riscos estão associados diretamente aos preços dos mais importantes itens do mercado de fatores e produtos. Por isso, é necessário recorrer ao entendimento dos resultados das análises de sensibilidade.

Através das análises de sensibilidade, foi possível verificar quais os itens que causaram maior impacto sobre a rentabilidade. Nos quadros a seguir (Quadro 10, Quadro 13, Quadro 14), estão listados, em ordem decrescente, os itens que causam maior impacto na rentabilidade, medida, neste caso, através do VPL. Para efeito desses cálculos foi considerado o valor da terra.

No caso do mercado de fatores, foi estipulada uma variação positiva nos preços e, no caso do mercado, de produtos uma variação negativa. 


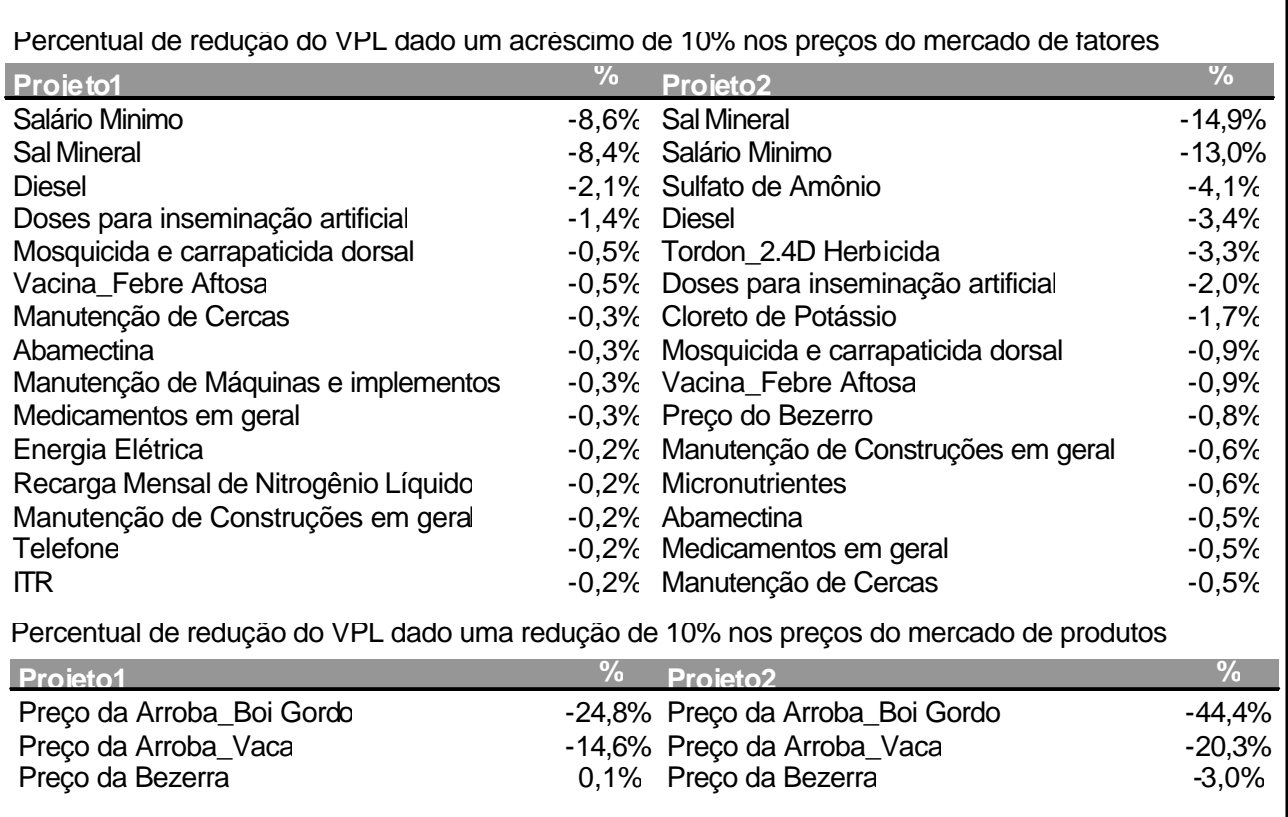

Quadro 12 - Resultados da análise de sensibilidade para os projetos 1 e 2 análise B4.

Fonte: Dados da pesquisa.

\begin{tabular}{|c|c|c|c|}
\hline \multicolumn{4}{|c|}{ Percentual de reduçäo do VPL dado um acréscimo de $10 \%$ nos preços do mercado de fatores } \\
\hline Proieto3 & $\%$ & Projeto 4 & $\%$ \\
\hline $\begin{array}{l}\text { Sal Mineral } \\
\text { Salário Minimo }\end{array}$ & $\begin{array}{l}-6,5 \% \\
-6,4 \%\end{array}$ & $\begin{array}{l}\text { Salário Minimo } \\
\text { Sal Mineral }\end{array}$ & $\begin{array}{l}-4,2 \% \\
-3,8 \%\end{array}$ \\
\hline Diesel & $-2,2 \%$ & Termofosfato de Yoorin & $-2,4 \%$ \\
\hline Termofosfato de Yoorin & $-2,1 \%$ & Diesel & $-1,7 \%$ \\
\hline Semente de Brachiaria Brizanta & $-1,7 \%$ & Semente de Brachiaria Brizanta & $-1,1 \%$ \\
\hline $\begin{array}{l}\text { Sulfato de Amônio } \\
\text { Doses para inseminação artificial }\end{array}$ & $\begin{array}{l}-1,6 \% \\
-0,9 \%\end{array}$ & $\begin{array}{l}\text { Semente de Arroz com tratamento } \\
\text { Cloreto de Potássio }\end{array}$ & $\begin{array}{l}-1,0 \% \\
-0,8 \%\end{array}$ \\
\hline $\begin{array}{l}\text { Cloreto de Potássio } \\
\text { Tordon_2.4D Herbicida }\end{array}$ & $\begin{array}{l}-0,7 \% \\
-0,7 \%\end{array}$ & $\begin{array}{l}\text { Doses para inseminação artificial } \\
\text { Basagran } 500 \text { Herbicida }\end{array}$ & $\begin{array}{l}-0,6 \% \\
-0,3 \%\end{array}$ \\
\hline Mosquicida e carrapaticida dorsal & $-0,4 \%$ & Sulfato de Amônio & $-0,3 \%$ \\
\hline Vacina Febre Aftosa & $-0,4 \%$ & Micronutrientes & $-0,3 \%$ \\
\hline Manutenção de Construções em geral & $-0,3 \%$ & Ally Herbicida & $-0,3 \%$ \\
\hline Abamectina & $-0,2 \%$ & Gramoxone Herbicida & $-0,3 \%$ \\
\hline Medicamentos em geral & $-0,2 \%$ & Klap Formicida & $-0,2 \%$ \\
\hline Micronutrientes & $-0,2 \%$ & Gladium_Herbicida & $-0,2 \%$ \\
\hline \multicolumn{4}{|c|}{ Percentual de reduçao do VPL dado uma reduçao de $10 \%$ nos preços do mercado de produtos } \\
\hline Projeto3 & $\%$ & Projeto 4 & $\%$ \\
\hline Preço da Arroba_Boi Gordo & $-22,0 \%$ & Preço da Arroba_Boi Gordo & $-10,3 \%$ \\
\hline Preço da Arroba Vaca & $-4,9 \%$ & Recuperacao Arroz & $-9,4 \%$ \\
\hline Preço da Bezerra & $-2,0 \%$ & Preço da Arroba_Vaca & $-5,5 \%$ \\
\hline
\end{tabular}

Quadro 13 - Resultados da análise de sensibilidade para os projetos 3 e 4 análise B4.

Fonte: Dados da pesquisa. 


\begin{tabular}{|c|c|c|c|}
\hline \multicolumn{4}{|c|}{ Percentual de redução do VPL dado um acréscimo de $10 \%$ nos preços do mercado de fatores } \\
\hline Projet05 & $\%$ & Projetoc & $\%$ \\
\hline Salário Minimo & $-5,3 \%$ & Salário Minimo & $-3,0 \%$ \\
\hline Sal Mineral & $-4,1 \%$ & Sal Mineral & $-2,5 \%$ \\
\hline Termofosfato de Yoorin & $-2,4 \%$ & Diesel & $-0,8 \%$ \\
\hline Diesel & $-1,8 \%$ & Doses para inseminação artificial & $-0,5 \%$ \\
\hline Cloreto de Potássio & $-1,2 \%$ & Semente de Brachiaria Brizanta & $-0,3 \%$ \\
\hline Semente de Soja com tratamento & $-1,2 \%$ & Mosquicida e carrapaticida dorsal & $-0,2 \%$ \\
\hline Semente de Brachiaria Brizanta & $-1,1 \%$ & Vacina_Febre Aftosé & $-0,1 \%$ \\
\hline Basagran 500_Herbicida & $-0,7 \%$ & Abamectina & $-0,1 \%$ \\
\hline Doses para inseminação artificial & $-0,6 \%$ & Medicamentos em geral & $-0,1 \%$ \\
\hline Adub.Foliar_Sulfato de Manganês & $-0,5 \%$ & Manutenção de Construções em geral & $-0,1 \%$ \\
\hline Dissulvan_Inseticida & $-0,4 \%$ & Manutenção de aceiros & $-0,1 \%$ \\
\hline Klap_Formicida & $-0,4 \%$ & Manutenção de Máquinas e implementos & $-0,1 \%$ \\
\hline Lorsban 480BR_Inseticida & $-0,3 \%$ & Semente de Tanzânia & $-0,1 \%$ \\
\hline Mosquicida e carrapaticida dorsal & $-0,2 \%$ & Recarga Mensal de Nitrogênio Líquido & $0,0 \%$ \\
\hline Preço do Bezerro & $-0,2 \%$ & Energia Elétrica & $0,0 \%$ \\
\hline \multicolumn{4}{|c|}{ Percentual de reduçao do VPL dado uma reduçao de $10 \%$ nos preços do mercado de produtos } \\
\hline Projet05 & $\%$ & Projetot a s a & $\%$ \\
\hline Preço da Arroba_Boi Gordo & $-12,3 \%$ & Preço da Arroba_Boi Gordc & $-6,8 \%$ \\
\hline Recuperacao Soia & $-10,5 \%$ & Preço da Arroba_Vací & $-2,8 \%$ \\
\hline Preço da Arroba_Vace & $-4,1 \%$ & Preço do Bezerrō & $-1,5 \%$ \\
\hline
\end{tabular}

Quadro 14 - Resultados da análise de sensibilidade para os projetos 5 e 6 análise B4.

Fonte: Dados da pesquisa.

Pelos resultados apresentados, é possível verificar que variações iguais no valor da mão-de-obra, do sal mineral e do óleo diesel são as que causam os maiores impactos, no sentido de deprimir a rentabilidade de todos os projetos. No caso das variações adversas aos preços dos produtos, verifica-se que, por serem propriedades embasadas nos sistemas de cria-recria-engorda, \&s preços da arroba do boi e da vaca têm influência significativamente maior do que os preços dos animais jovens. Contudo, nota-se também que a de influência dos preços de arroz e soja, culturas que embora sejam realizadas em áreas reduzidas (10\% da área com potencial de mecanização), assumem importância significativa quanto ao preço da arroba do boi. Entretanto, o período utilizado na condução das simulações (últimos cinco anos) demonstra que os preços médios mensais da saca de $60 \mathrm{~kg}$ do arroz e da soja (preços do MT, como proxy dos preços de RO), variaram de forma bastante semelhante (Gráfico 26). Dado que as produtividades e insumos utilizados nas parcelas experimentais são parecidos, o risco das duas formas de recuperação, conseqüent emente, também ficaram bastante próximos. 


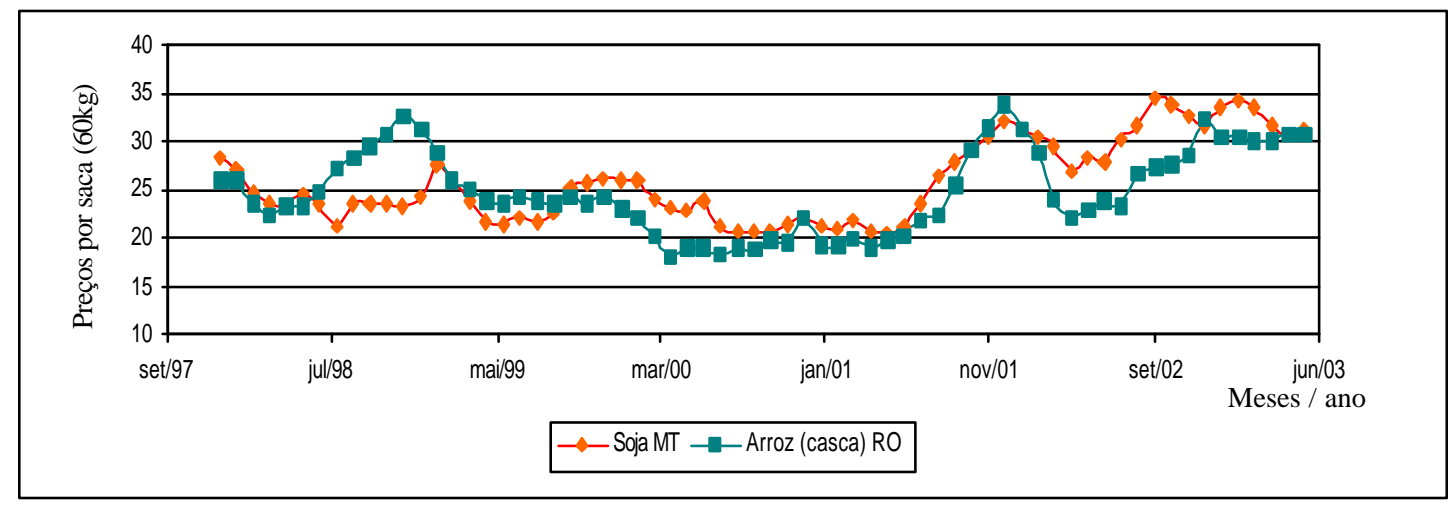

Gráfico 26 - Série de preços: soja e arroz.

Fonte: FGV (2003b)

\subsubsection{A viabilidade econômica do desmatamento em relação às práticas de recuperação de pastagem}

Neste estudo, os riscos associados à produtividade não foram levados em consideração. Os fatores climáticos representam uma ameaça menos significativa no estado de Rondônia do que em outras regiões no país. O período de estiagem é relativamente curto e os problemas ficam mais associados ao excesso do que àfalta de chuvas, especialmente na época da colheita. De qualquer forma, os agricultores da região de Vilhena ressaltam que esse tipo de problema não foi um empecilho nos últimos anos.

Um dos principais riscos à introdução de uma nova tecnologia corresponde ao capital humano do meio rural, mas isso não é uma particularidade apenas da região amazônica. Em praticamente todos os locais onde foram executados os painéis, o problema da baixa eficiência da mão-de-obra é um grave fator que pode prejudicar o retorno de investimentos aplicados em máquinas e insumos.

A inclusão desses riscos nos modelos traria mais vantagens à ação do desmatamento. A experiência de anos daqueles que realizam a abertura de novas áreas e o baixo grau de especialização do trabalho necessário para tal minimizariam os riscos de insucesso para o capital investido na queima da floresta.

Além do baixo risco, é difícil acreditar que uma área de mata, do porte das florestas equatoriais, transformada em cinzas, não agregará ao solo um potencial de 
fertilidade bastante alto. Aliado a esse fator, conforme as séries históricas mostradas no Gráfico 4, a diferença de valor entre a terra bruta e a terra pasto, nos últimos dez anos, sempre foi suficiente para cobrir os custos da supressão da floresta. Isso sem contabilizar os ganhos que alguns produtores aferem com a extração de madeira, dependendo do local onde é realizado o desmatamento.

No presente trabalho, o potencial de exploração da terra foi limitado em 20\%, conforme o texto da Medida Provisória n 2166 de 24/08/2001 (Brasil, 2001), que altera o caput, as alíneas e os parágrafos do artigo 16 da Lei 4771 de 15/09/1965 (Brasil, 1965). Embora isso esteja descrito em medidas provisórias com força de lei e, sendo que, os novos textos legais a serem publicados possam ser mais rígidos com relação à área de reserva mínima permitida, o desrespeito à lei por aqueles que fazem o desmatamento é muito grande.

Mesmo respeitando o limite de uso do solo em $20 \%$ da área, o projeto 6, com desmatamento, já se torna superior aos de recuperação, quando o valor da terra é agregado. Se proporções maiores que $20 \%$ forem desmatadas, obviamente as taxas serão ainda maiores. Em termos reais os percentuais efetivamente deixados como áreas de reservas são inferiores ao determinado em lei (80\%).

No Gráfico 27, é possível observar que a quantidade da área desmatada na Amazônia Legal, estimada pelo INPE, em relação à área autorizada pelo IBAMA, nos anos de 1997 a 1999, deve estar muito além dos limites impostos pela legislação em vigor. 


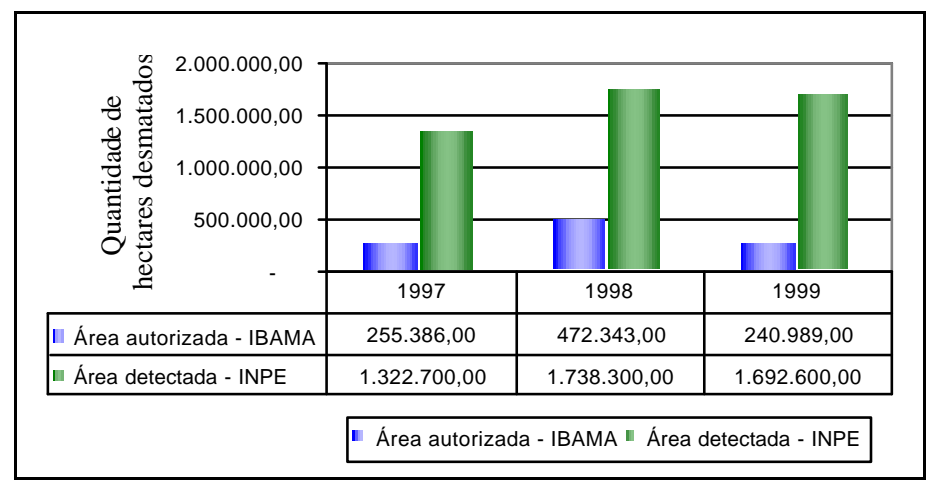

Gráfico 27 - Área autorizada e área desmatada, 1997-1999.

Fonte: IBAMA (2002)

De acordo com o artigo $15^{\circ}$ e $16^{\circ}$ do Código Florestal, é necessário que sejam seguidos os critérios, atualmente, determinados pela Instrução Normativa 03/2001 (Brasil, 2002). Por isso, todas as áreas, dentro dos padrões legais, a serem desmatadas deveriam ter a autorização do IBAMA. Conclui-se, portanto, que seja provável que o desmatamento abranja proporções maiores que 20\%. Nessas condições, o agente que realiza a supressão da floresta encontrará taxas de retorno superiores às que foram encontradas neste estudo.

Uma prova empírica das vantagens do desmatamento mesmo sob a pressão contrária determinada pela legislação e pela sociedade, de acordo com a reunião de todos fatores anteriormente descritos, é o retorno do crescimento da área desmatada, na região amazônica, nos últimos anos, segundo dados do INPE (Gráfico 28).

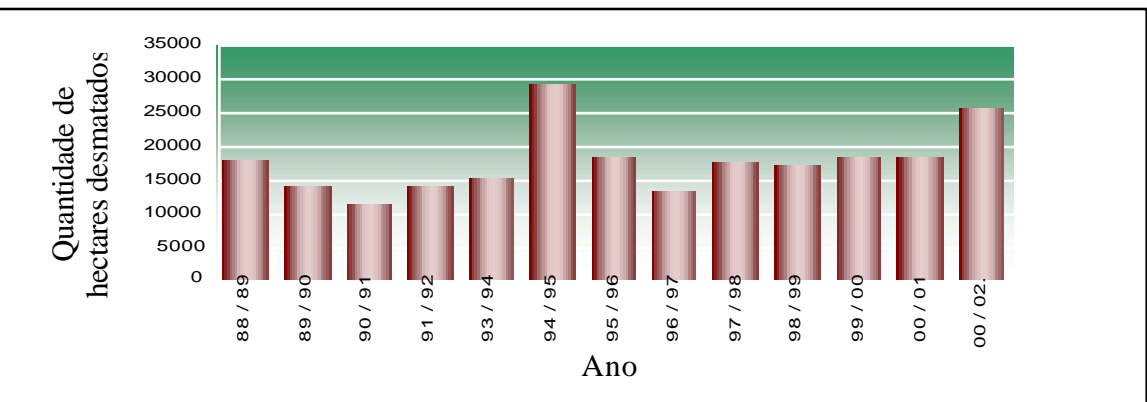

Gráfico 28 - Evolução do desmatamento - hectares por ano.

Fonte: INPE (2003) 


\section{CONCLUSÕES}

A análise dos resultados, apresentados no item anterior, permite concluir que a taxa de lotação inicial e as hipóteses referentes àvalorização da terra destacam-se como variáveis principais na definição da preferência por projetos.

Pôde-se constatar que o projeto que não adota tecnologias suplementares, restringindo-se apenas ao manejo convencional foi preferível nas situações em que o percentual de valorização da terra é baixo. Isso é explicado pela circunstância atual da capacidade de suporte das pastagens no estado de Rondônia. A taxa de lotação ao redor de 1,05 UA/ha, dispensa o uso das técnicas de recuperação da pastagem descritas neste trabalho, entretanto, para os casos em que os pastos detêm menores níveis de produtividade (abaixo de 0,73 UA/ha), os sistemas de recuperação indiretos (utilização dos cultivos de soja e arroz para recuperar o pasto) se mostraram economicamente mais favoráveis, co resultados superiores aos outros sistemas de recuperação - que utilizam operações diretas sobre a pastagem - e ao sistema de produção convencional

Caso as perspectivas de aumento do valor da terra sejam consistentes, quando as áreas de mata nativa são transformadas em áreas de pastoreio, as vantagens econômicas do desmatamento são superiores às das técnicas utilizadas para recuperar o pasto e ao sistema de produção convencional. Assim, quando os valores associados à valorização da terra são somados, a melhor escolha, em termos econômicos, volta-se para a opção do desmatamento, dentro das considerações assumidas neste estudo.

Por serem projetos ligados à pecuária de corte extensiva, a valorização imobiliária é um fator decisivo no processo de tomada de decisão. $\mathrm{O}$ avanço das fronteiras de desenvolvimento pode determinar a viabilidade dos projetos, em especial, daqueles relacionados com a agricultura, uma vez que o desenvolvimento de toda a 
infra-estrutura agropecuária - distribuidoras de insumos, assistência técnica e os canais de comercialização - locomove-se em conjunto com o processo de expansão das fronteiras agrícolas.

Conforme os resultados obtidos, é necessário destacar que a opção do desmatamento é economicamente preferível na maioria dos casos, pois os atos colonizadores são quase sempre compensados pelos ganhos imobiliários. Mesmo respeitando os limites legais das áreas de reservas (80\%) e sem considerar os ganhos com a extração da madeira durante o desmatamento, os benefícios concedidos pelas técnicas de recuperação de pastagens ainda são inferiores. O desenvolvimento regional do setor agrícola e de suas vias de escoamento facilitaria a adoção de novas tecnologias destinadas à recuperação do solo, mas é provável que a capitalização da terra, dada pela expansão agrícola, agravaria o processo de supressão da floresta, com o deslocamento das áreas pastoris para regiões mais remotas.

Também são importantes, mas que não foram analisados, itens como a forma gerencial de condução das vendas de animais nos períodos de entressafra e o horizonte temporal adotado podem promover alteração na ordem de escolha.

Ressalta-se que o horizonte temporal usado neste trabalho (oito anos) pode ser considerado curto, mas foi necessário devido à influência que o fator terra exerce sobre o processo de tomada de decisões nas regiões onde o processo de colonização é bastante ativo. Entretanto, futuros estudos desse tipo podem ser conduzidos com intervalos de tempo maiores, de forma a reduzir a importância do valor da terra nas análises. Nesse caso o ordenamento dos projetos ficará basicamente submetido às diferenças associadas ふ̀ tecnologias adotadas, pois os montantes de valores gerados por extensos fluxos de caixa e a redução dos valores futuros, determinada pelas taxas de juros, tendem a minimizar a importância da valorização da terra.

Outra forma de refinar a avaliação, especificamente sobre as diferenças ocasionadas pela adoção da tecnologia em si, de forma a reduzir a importância do fator terra nas análises, seria a utilização de outros métodos para ordenar a preferência pelos projetos. Os métodos associados àprogramação linear e ao orçamento parcial poderiam, além de ordenar, analisar de forma concomitante, dentro de um único sistema de 
produção, as vantagens econômicas de cada tecnologia. Com isso, seria possível fazer inferências sobre a otimização de várias práticas quando utilizadas simultaneamente.

É possível ainda que os projetos que visem à recuperação de pastagens sejam viáveis e mais interessantes sob outras condições. Nesse trabalho, o tamanho das áreas recuperadas por ano tornam os investimentos depositados em máquinas e implementos subutilizados. Outros estudos podem determinar a área mínima necessária para viabilizar as práticas de intensificação do uso do solo. 


\section{REFERÊNCIAS BILIOGRÁFICAS}

AGUIAR, A.P.A. Manejo de pastagens. Guaíba: Livraria e Editora Agropecuária, 1998. 139p.

AMBRÓSIO, L.A. Planejamento do uso sustentável da terra em microbacias hidrográficas: uma abordagem de programação por metas. Piracicaba, 1997. 145p. Tese (Doutorado) - Escola Superior de Agricultura "Luiz de Queiroz", Universidade de São Paulo.

ARRUDA, Z.J.; SUGAI, Y. Regionalização da pecuária bovina no Brasil. Campo Grande: Embrapa, CNPGC. Brasília: EMBRAPA, SPI, 1994. 144p. (EMBRAPA, CNPGC. Documentos, 58)

AZEVEDO FILHO, A.J.B.V. Análise econômica de projetos: "software" para situações deterministas e de risco envolvendo simulação. Piracicaba, 1988. 127p. Dissertação (Mestrado) - Escola Superior de Agricultura "Luiz de Queiroz", Universidade de São Paulo.

AZEVEDO FILHO, A.J.B.V.; PERES, F.C. Competitividade da cultura da soja em uma empresa da região de Campinas, SP. In: CONTINI, E.; ARAUJO, J.D.; OLIVEIRA, A.J. et al. Planejamento da propriedade agrícola: modelos de decisão. Brasília: EMBRAPA, DDT, 1984. p.289-300. 
BRASIL. Leis, decretos, etc. Lei Ordinária. no 4771 de 15 de setembro de 1965. http://wwwt.senado.gov.br/legbras/ (02 out. 2002)

BRASIL. Leis, decretos, etc. Medida Provisória. no 2166 de 24 de agosto de 2001. http://wwwt.senado.gov.br/legbras/ (02 out. 2002)

BRASIL. Ministério da Agricultura, Pecuária e Abastecimento. Departamento de Defesa Animal - DIPOA. Instrução Normativa $n^{\circ}$ 6, de 13 de Julho de 2000. http://www.agricultura.gov.br/sda/ (04 out. 2002)

BRASIL. Ministério do Meio Ambiente. Instituto Brasileiro do Meio Ambiente e dos Recursos Naturais Renováveis - IBAMA. Instrução Normativa $\mathbf{n}^{0}$ 3, de 4 de Março de 2002. http://www2.ibama.gov.br/ (04 out. 2002)

BUARQUE, C. Avaliação econômica de projetos: uma apresentação didática. 6.ed. Rio de Janeiro: Campus, 1991. 266p.

COBLE, H.K.; KNIGHT, T.O.; POPE, R.D.; WILLIANS, J.R. Modeling farm-level crop insurance demand with panel data. American Journal of Agricultural Economics, v.78, n.2, p.439-447, May 1996.

CONTADOR, C.R. Avaliação social de projetos. São Paulo: Atlas, 1981. 301p.

CONTINI, E.; ARAUJO, J.D.; GARRIDO, W.E. Instrumental econômico para a decisão na propriedade agrícola. In: CONTINI, E.; ARAUJO, J.D.; OLIVEIRA, A.J. et al. Planejamento da propriedade agrícola: modelos de decisão. Brasília: EMBRAPA, DDT, 1984. p.7-22. 
COSTA, A.N. da; CARVALHO, D.L.O.M. de; TEIXEIRA, B.L.; SIMÃO NETO, M Pastagens cultivadas na amazônia. Belém: EMBRAPA, Amazônia Oriental, 2000. $151 \mathrm{p}$.

CRUZ, E.R. da. Aspectos teóricos sobre incorporação de risco em modelos de decisão. In: CONTINI, E.; ARAUJO, J.D.; OLIVEIRA, A.J. et al. Planejamento da propriedade agrícola: modelos de decisão. Brasília: EMBRAPA, DDT, 1984. p.237-260.

DE ZEN, S. Diversificação como forma de gerenciamento de risco na agricultura. Piracicaba, 2002. 101p. Tese (Doutorado) - Escola Superior de Agricultura "Luiz de Queiroz", Universidade de São Paulo.

DHUMUL, W.V. Economic theory and operations analysis. 4.ed. New Jersey: Prentice-Hallinc, 1977. 695p.

FALESI, I.C. Ecossistema da pastagem cultivada na Amazônia brasileira. Belém: EMBRAPA, CPATU, 1976. 32p. (EMBRAPA, CPATU. Boletim de Pesquisa)

FALESI, I.C.; VEIGA J.B. O solo da Amazônia e as pastagens cultivadas. In: PEIXOTO, A.M. Pastagens na Amazônia. Piracicaba:FEALQ, 1986. p.1-26.

FONSECA, M.I. Estudo da adoção de tecnologia na pecuária de leite na área de ação da CAMIV - Cooperativa Agrícola Mista de Viçosa. Viçosa, 1991. 141p. Dissertação (Mestrado) - Universidade Federal de Viçosa.

FUNDAÇÃO GETÚLIO VARGAS - FGV. Séries históricas de preços: terras do estado de Rondônia . http://www.fgv.br/ (09 ago. 2003) 
FUNDAÇÃO GETÚLIO VARGAS - FGV. Séries históricas de preços: produtos agropecuários. http://www.fgv.br/ (09 ago. 2003)

GONTIJO, R. Aonde nos leva esta estrada? In: MORAIS, F. Transamazônica. São Paulo: Brasiliense, 1970. p.49-102.

HECHT, SB.; NORGAARD, R.B.; POSSIO, A.G. Economia da pecuária na Amazônia Oriental. Estudos Econômicos, v.18, n.1, p.93-112, 1998.

HILLIER, F.S. Introdução à pesquisa operacional. Rio de Janeiro: Campus; São Paulo: EDUSP, 1988. 805p.

HOMMA, A.K.O. Expansão da fronteira agrícola na Amazônia: lucros decorrem da especulação ou do processo produtivo? In: HOMMA, AK.O. Extrativismo vegetal na Amazônia: limites e oportunidades. Belém: EMBRAPA, Amazônia Oriental; Brasília: EMBRAPA, SPI, 1993. p.121-136.

HOMMA, A.K.O. As questões emergentes e a agricultura na Amazônia (compact disc). In: CONGRESSO BRASILEIRO DE ECONOMIA E SOCIOLOGIA RURAL, 37., Foz do Iguaçu, 1999. Anais. Brasília: SOBER, 1999.

INSTITUTO BRASILEIRO DE GEOGRAFIA E ESTATÍSTICA - IBGE. Sistema IBGE de recuperação automática: pesquisa pecuária municipal, 2001. http://www.sidra.ibge.gov.br/bda/ (02 abr. 2002)

INSTITUTO BRASILEIRO DE GEOGRAFIA E ESTATÍSTICA - IBGE. Sistema IBGE de recuperação automática: pesquisa agrícola municipal, 2001. http://www.sidra.ibge.gov.br/bda/ (02 abr. 2002) 
INSTITUTO BRASILEIRO DE GEOGRAFIA E ESTATÍSTICA - IBGE. Sistema IBGE de recuperação automática: censo agropecuário 1996. http://www.sidra.ibge.gov.br/bda/ (23 ago. 2002)

INSTITUTO BRASILEIRO DO MEIO AMBIENTE E DOS RECURSOS NATURAIS RENOVÁVEIS - IBAMA. Informativo Técnico nf 01 / 2002 - Desmatamento. http://www2.ibama.gov.br/desmatamento/informativos/desmatamento_2003.pdf set. 2003)

INSTITUTO NACIONAL DE PESQUISAS ESPACIAIS - INPE. Programa de monitoramento de queimadas e prevenção e controle de incêndios florestais no arco do desflorestamento na amazônia: áreas florestais, 1999. http://www.dpi.inpe.br/proarco/ (05 jun. 2002)

INSTITUTO NACIONAL DE PESQUISAS ESPACIAIS - INPE. Programa de monitoramento de queimadas e prevenção e controle de incêndios florestais no arco do desflorestamento na Amazônia. http://www.inpe.br/ (12 jul. 2003)

KNIGHT, F.H. Risco, incerteza e lıcro. Rio de Janeiro: Expressão e Gultura, 1972. $385 p$.

MATTOS, M; UHL, C. Perspectivas econômicas e ecológicas da pecuária na Amazônia oriental na década de 90. In: ALMEIDA, O. A evolução da fronteira amazônica: oportunidades para um desenvolvimento sustentável. Porto Alegre: Edições Caravela; Belém: Imazon, 1996. p.39-66.

MARTINES FILHO, J.G.; PERES, F.C. Mecanismos de administração de riscos. Piracicaba: ESALQ, Depto. Economia, Sociologia e Administração, 1998. p.232254. (Série Didática,122) 
MUELLER, C.C. Pecuária de corte no Brasil central: resultado das simulações com modelos de programação linear. Revista de Economia Rural, v.2, n.1, p.103-161, 1977.

NASCIMENTO JUNIOR, D. do; QUEIROZ, D.S.; SANTOS, M.V.F. dos. Degradação das pastagens e critérios para avaliação. In: SIMPÓSIO SOBRE MANEJO DA PASTAGEM, 11., Piracicaba, 1994. Anais. Piracicaba: FEALQ, 1994. p.107-152.

NEVES, E.M. Análise econômica do investimento em condições de risco na cultura da borracha. Piracicaba, 1984. 171p. Tese (Livre-Docência) - Escola Superior de Agricultura “Luiz de Queiroz", Universidade de São Paulo.

SILVA NETO, A.L. Análise e decisão de investimento: um estudo de caso (compact disc). In: CONGRESSO BRASILEIRO DE ECONOMIA E SOCIOLOGIA RURAL, 37., Foz do Iguaçu, 1999. Anais. Brasília: SOBER, 1999.

NORONHA, J.F. Projetos agropecuários: administração financeira, orçamento e viabilidade econômica. São Paulo: Atlas, 1987.269p.

PEIXOTO, A.M.; MOURA, J.C.; FARIA, V.P. Pastagens na Amazônia. Piracicaba: FEALQ, 1986. 99p.

PERES, F.C. Planejamento da empresa agrícola em condições de risco. In: CONTINI, E.; ARAUJO, J.D.; OLIVEIRA, A.J. et al. Planejamento da propriedade agrícola: modelos de decisão. Brasília: EMBRAPA, DDT, 1984. p.273-287.

POMERANZ, L. Elaboração e análise de projetos. São Paulo: Hucitec, 1985. 246p.

PEREIRA, O.D. A Transamazônica: prós e contras. 2.ed. Rio de Janeiro: Civilização Brasileira, 1971. 429p. 
SANTOS, Z.A.P.S. Adoção tecnológica na agricultura paulista. São Paulo: Instituto de Pesquisas Econômicas - IPE/USP, 1984. 100p.

REUTLINGER, S. Techniques for project appraisal under uncertainly. 5.ed. Baltimore: The Johns Hopkins University Press, 1984. 95p.

SCHNEIDER, R.R.; ARIMA, A.; VERISSIMO, A. et al. Amazônia sustentável: limitantes e oportunidades para o desenvolvimento rural. Brasília: Banco Mundial; Belém: Imazon, 2000. 58p.

THAMER, A. Transamazônica: solução para 2001. Rio de Janeiro: APEC Editora, 1970. $275 \mathrm{p}$. 